\title{
Ethnobotanical Survey of Flora Used in Maasai Food System and Traditional Medicine against Gout- related and Other Human Ailments in Monduli, Arusha, Tanzania
}

\section{Richard Paul Clement ( $\square$ clementr@nm-aist.ac.tz)}

Mkwawa University College of Education https://orcid.org/0000-0002-4800-0558

Jofrey Raymond

Nelson Mandela African Institute of Science and Technology School of Life Sciences and BioEngineering

Musa N Chacha

Nelson Mandela African Institute of Science and Technology School of Life Sciences and BioEngineering

\section{Research}

Keywords: Ethnobotany, Flora, Food, Gout, Maasai, Traditional medicine, Monduli

Posted Date: September 1st, 2021

DOl: https://doi.org/10.21203/rs.3.rs-838942/v1

License: (c) (1) This work is licensed under a Creative Commons Attribution 4.0 International License.

Read Full License 


\title{
Ethnobotanical survey of flora used in Maasai food system and traditional medicine against gout-related and other human ailments in Monduli, Arusha, Tanzania
}

\author{
Richard P Clement $^{1,2^{*}}$, Jofrey Raymond ${ }^{1}$, Musa N Chacha ${ }^{1}$
}

\author{
${ }^{1}$ School of Life Sciences and Bioengineering, The Nelson Mandela African Institution of Science \\ and Technology, P. O. Box 447, Arusha, Tanzania \\ ${ }^{2}$ Mkwawa University College of Education, A constituent College of the University of Dar es \\ Salaam, P. O. Box 2513, Iringa, Tanzania
}

*Correspondence: clementr@nm-aist.ac.tz; richardclement28@gmail.com

$1^{\text {st }}$ Co-author: musa.chacha@nm-aist.ac.tz

$2^{\text {nd }}$ Co-author: jofrey.raymond@nm-aist.ac.tz 


\begin{abstract}
Background: Flora used by Maasai practitioners (MSPs) in traditional medicine (TM) and food system (FS) were investigated in Monduli District, Arusha, Tanzania. The objective of this study was to document the knowledge on flora used by MSPs in their FS and TM against gout-related and other ailments.
\end{abstract}

Methods: Ethnobotanical knowledge held by 21 MSPs was investigated following standard approaches. Guided field walk, free listing, rigorous individual-interviews and local market surveys were employed to obtain information. Use value (UV) index, relative frequency of citation (RFC), specific RFC (RFCs), fidelity level (FL) and informant consensus factors (ICF) matrices were involved to determine the knowledge on flora used in Maasai FS and TM against gout-related and other ailments.

Results: A total of 101 plant species in 83 genera and 47 families, used in Maasai FS and TM were recorded. Food, food processing or storage, and medicinal plant (MPs) flora accounted 29, 32 and 80 species respectively. MPs treated more than 38 ailments. A high proportion of plants recovered, was trees $45.19 \%$; while $88.79 \%$ were retrieved from the wild habitat. Roots were mostly used part $(30.73 \%)$; preparations were made from fresh or dry material and 44-species involved decoction in meat broth or stock. The frequently route of delivery was oral, $85.19 \%$. About $37.5 \%$ of the MPs were used to treat joints' pain or inflammation (ICF $=0.52)$ whereas, mostly used was Rapanea melanophloeos $(\mathrm{FL}=1.00 ; \mathrm{RFC} s=0.29)$ followed by Withania somnifera $(\mathrm{FL}=0.5$; RFCs $=0.24)$. Withania somnifera frequently used against other gout-related ailments. Vangueria infausta and Olea europaea subsp. Africana uses in FS ranked the highest.

Conclusion: The study area is very rich in flora biodiversity, and the flora is an integral part of the indigenous foods' and health care systems. The flora is exposed to various destructive anthropogenic activities; thus, integrated conservation measures are required. The rich ethnobotanical knowledge held by MSPs, requires an in-depth study and documentation. Investigations of flora used in the FS, and TM, with high FL, and RFCs could contribute to future nutraceuticals and drug discovery against gout and other ailments.

Keywords: Ethnobotany, Flora, Food, Gout, Maasai, Traditional medicine, Monduli 


\section{Background}

Flora used in indigenous food systems (FS) or traditional medicine (TM) play a significant role in promoting individual health and well-being particularly in the disadvantaged communities across the word [1-3]. For instance, globally, floral species used in folk medicine account 35,000-70,000 species [1]. Besides, $60-80 \%$ of the developing countries rely on the medicinal flora while $30-49 \%$ of the population in developed countries such as China, Germany, Australia, USA and France, is extensively using medicinal flora [1]. In addition, some floral species are known to provide both nutritional and medicinal benefits while some are used in processing foods in the indigenous food systems [2-5]. Still, $25 \%$ of the contemporary allopathic drugs are derived directly from flora or synthetic analogies of different compounds isolated from medicinal flora [1]. Dependency of flora resources on such benefits is attributed by existing poverty, cultural conservatism and perceived efficacy, safety, easy accessibility and lower cost of the flora [6].

Tanzania, one of the mega-biodiversity rich country and sixth topmost known biodiversity hotspots, is not left behind from such benefits of flora biodiversity [6-11]. The country is endowed with widespread diversity of species with at least 14,500 known and confirmed species [9] whereas, flora accounts 12, 667 species, and 1122 species of it are endemic while more than 375 of the species are more threatened [6,9]. Despite the threats and endemism on some Tanzanian floral species, still the flora biodiversity supports large population living in both rural and urban area for their health and well-being [7,8,10,11]. An estimate of more than 60\% (45 million people) of the Tanzanian population in both rural and urban areas, depends mainly on flora-based traditional medicines as a vital components of their primary health care and as a means of generating income [6,12]. In addition, about 69.1\% (35 million) of the Tanzania population live in rural area and $80 \%$ of them depend on the flora resources for such needs [6]. Moreover, some flora species are used as food sources or added in food to provide dietary and or medicinal role in the indigenous peoples' food systems $[2,4,5]$.

Traditional knowledge on flora biodiversity up to the current time is still held by many rural communities and is varying among them depending on their cultural reflections [1]. The cultural reflection can change individual view point about the environment and also guide interactions between human being and resources in the ecosystem [1,4]. Consequently, the traditional knowledge is varying from one culture to the other regardless being in the same ecosystem and 
thus the varying benefits of their traditional knowledge [1]. This also suggest that community with strong uphold of their culture are likely to have broader traditional knowledge which is reflected in their characteristic cultural values such as those of Maasai $[4,5]$.

Maasai among other ethnic groups existing in Tanzania, have managed to keep many of their traditional life styles which support their livelihood [3,6]. Maasai nomadic life has allowed them to have an access of various biological resources, which has a significant contribution to their enormous ethnobotanical or traditional knowledge on their landscape [6]. Traditionally Maasai are pastoralists keeping cattle, sheep and goats, and sometimes donkeys which are used as a source of income and wealthy symbols [6]. In addition, Maasai depends on animals for foods such as blood, milk, meat and honey, though in recent days they consume other food sources like banana, beans, maize, potatoes, rice, and others [4-6].

Maasai along with other cultural practices have long known for their use of flora in their food system and traditional medicine which is deep-rooted in their life [3-6]. Maasai utilize flora in their food system and traditional medicine when they are health and during sickness condition [46]. Such dependency on flora in the food system and traditional medicine is attributed by the enormous knowledge they possess on nature as well as by their life in isolated areas where modern health care is inaccessible and unavailable [5,6]. Maasai are trained on the value of flora in their food system and traditional medicine since their childhood. In their age set system during 'orpul' festival of meat eating and healing, young boys and 'Morans', in addition to other skills and experiences, are thoroughly trained on flora used in the food system and traditional medicine [46]. On the other hand Maasai girls gain such knowledge from their mothers and grandmothers as they spend a lot of time with them [4-6]. Such training prepares 'Morans' or girls before and after entering elders group, (allowed to get married) capable of taking family responsibilities including, to ensure primary health care is provided at the household level through the use of flora in their food systems and traditional medicine $[5,6]$.

Use of flora in indigenous food system and traditional medicine by Maasai has been linked with the low prevalence of some diseases including metabolic diseases such as gout in their communities [3,13]. Gout has been reported to be uncommon in Maasai community predominantly to those who uphold their traditional life styles in food system and tradition medicine [3]. Gout risks factors include consumption of food with high purine contents, drinking sweetened drinks, 
alcohol particularly bear, genetic predisposition, health conditions such as diabetes, obesity, blood pressure, cancer, hyperlipidemia, kidney disease and some digestive system disorders [14-19] In contrast Maasai community regularly consume food sources such as meat from goat, cattle, and lamb with high purine content and fat yet gout is uncommon in their society especially those embracing their culture of using flora in their food system and traditional medicine [3]. In this respect flora used in Maasai food systems and traditional medicine have potential nutritional benefits and medicinal role in management of various human ailments including health conditions related to gout and its risk factors.

However, Maasai traditional knowledge on flora used in their food system and traditional medicine is less researched and documented. Still such knowledge is threatened to be lost by the changes toward a more western lifestyles, poor relation between young and old generation, urbanization, and over exploitation of the resources [1,6,20,21]

Therefore, this study aimed at conducting ethnobotanical survey to recover and document the traditional knowledge on flora used in Maasai food system and traditional medicine which manage various human ailments including gout related health conditions, in Maasai community of Monduli district, Arusha, Tanzania.

\section{Methods}

\section{Description of the study area}

The study was mainly conducted in Monduli District and some part of Arusha rural (see figure 1). Monduli district is one of seven districts located in the northeastern part of Tanzania in Arusha region. District has an area of 6,419 sq. Km of which land area covers 6290.62 sq. Km and water covers 128.38 sq. Km; whereas, grazing land covers 3,983.855 sq. Km, arable land covers 1,055.475 sq. Km and forest covers 374.965 sq. Km. Monduli district is bordered to the north by Longido District, to the east by Arusha rural district, to the south by Manyara region and to the west by Ngorongoro and Karatu district. Monduli Districts is situated between latitudes 3.00" to 4.50' South of the Equator and Longitudes 36.50' to 36.45' East of Greenwich Meridian. The district has 20 Wards and 62 villages. In this study ethnobotanical survey was conducted in seven villages. These villages included Lemiyoni, Makuyuni juu and Zaburi in Makuyuni ward; 
Lossimingori in Lepurko ward; Mlimani in Monduli; and Imbibia and Engalaon villages in Mwandeti ward found in Arusha rural close to Monduli forest reserve (see figure 1).

The district comprises of three climatic zones: highlands, flat and rolling plains, and rift valley zones. The zones are further categorized into two major agro-ecological zone: Highlands zone with average altitude of $2000 \mathrm{~m}$ and low land zone (flat and rolling plains) with altitude ranging from $600 \mathrm{~m}$ to $1200 \mathrm{~m}$ above sea level. Monduli district is one of driest district in Tanzania and has a warm climate in low altitude areas and cool climate in high altitude areas. District temperature is ranging between $20^{\circ} \mathrm{C}$ to $35^{\circ} \mathrm{C}$ while rainfall is ranging from less than $500 \mathrm{~mm}$ in low lands to $900 \mathrm{~mm}$ at high elevations. Soil characteristics of the district is classified based on the potential of land-use, into shallow soils with depth less than $40-50 \mathrm{~cm}$, dee soils and deep freely soil drainage soil with depth more than $40-50 \mathrm{~cm}$. The dominant soils are deep, freely drained clays with a moderate natural fertility status and occupy about $32 \%$ of the district.

Major Ethnic group in the district is Wamaasai constitutes about $40 \%$ of the entire population and their main activities is livestock keeping. The second ethnic group is Waarusha constitutes about $20 \%$ of the entire population and their main activities are livestock keeping and farming. The rest who are not indigenous of Monduli district constitutes $40 \%$ and their main activities are farming, trading and civil servants.

The population size of the district is 158,929 people out of 1,694,310 people of Arusha region as per National census of 2012 [22]. Sex distribution of the district population showed that males are 75,615 and females are 83,314 in number and the sex ratio was 91 . Average house hold size is 4.7 in the district. Monduli has one hospital, one health Centre, and 22 dispensaries. Furthermore, the study area has open markets were trading of various services and goods such as foods and traditional medicine are being conducted (figure 1) 


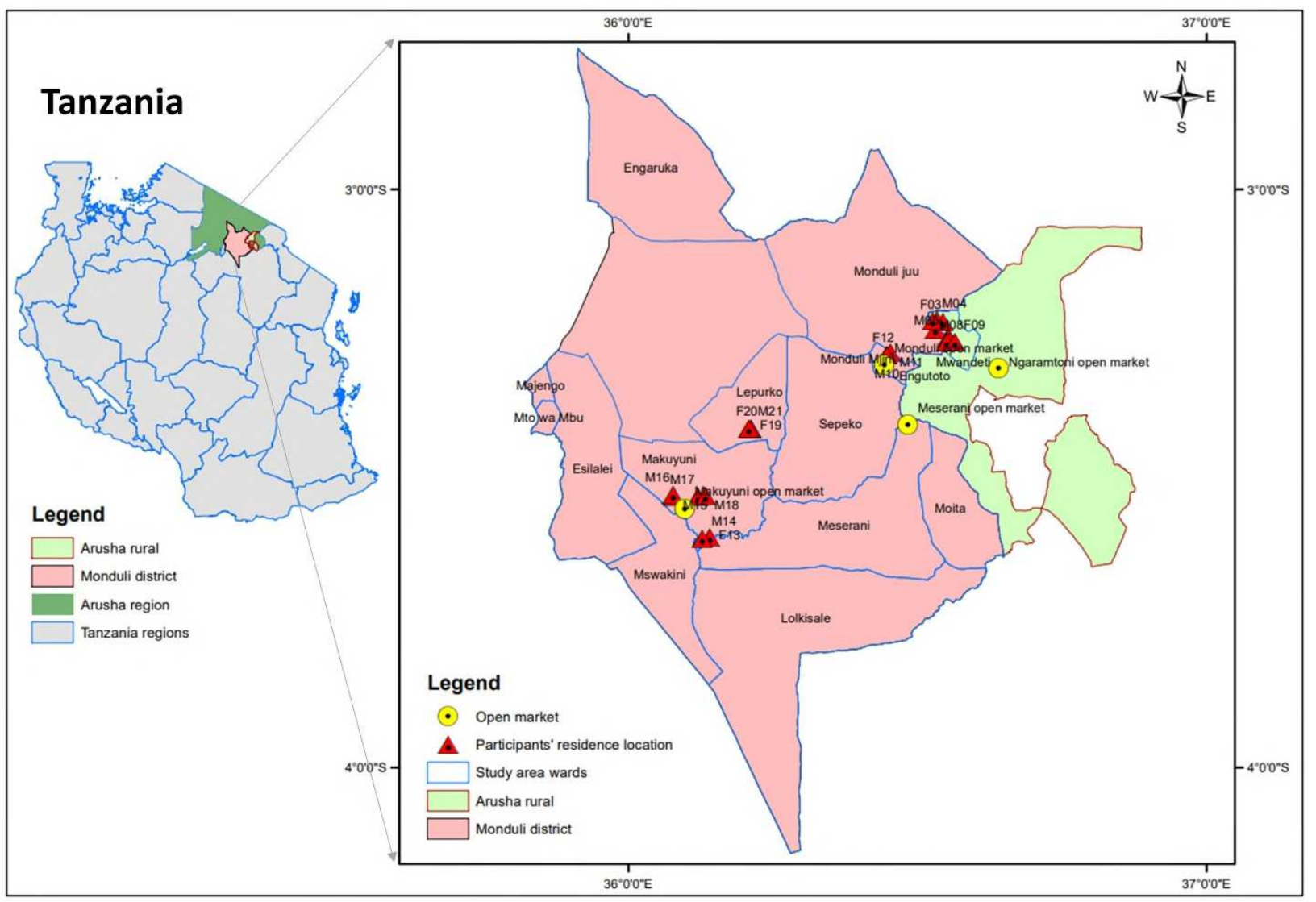

Figure 1 Location of open markets and participants' (MSPs) residence, selected as study site in Monduli District, Arusha Region, Tanzania

\section{Reconnaissance survey and informant selection}

Ethnobotanical survey started on June 2020 and end up after two months in August 2020 while collection of voucher specimens went up to April, 2021. Two (2) to three (3) days before the interview started, local administrator or village leaders were consulted and the theme of the research was introduced to them, where it served as the basis for their recommendation on the participants to be included in the study. Their recommendations were guided by the set criteria used to include or exclude the participants in the study. This study aimed at determining and documenting flora used in Maasai food system and traditional medicinal with emphasis to those used in management or making gout uncommon in Maasai community; therefore, Maasai respondents with much experience and knowledge on flora used in food system and traditional medicine as well as those with experience on gout disease, were required. Elders or marriage people with strong uphold of their culture in Maasai community are expected to hold enough 
knowledge and practices on flora used in food system and traditional medicine through their traditional training in 'orpul' festival as well as past experiences from their ancestors, and they have obligation to ensures primary health care is provided at family level. Participants were also included based on the age where the lowest age for a male participant was not below 30 years as it qualifies for being elder/married with enough ethnobotanical knowledge and experience as well as it was the age for risk of getting gout, and its experience. Female were included bases on married experience and or age at menopause which qualifies for enough ethnobotanical knowledge and experiences as well as age at risk of acquiring gout and its experiences. Twenty-one (21) MSPs (15 males and 6 females) were identified from total of seven (7) villages and their backgrounds were recorded (Table 1). The villages from which respondents were recruited are Mlimani, Lossimingori, Makuyuni juu, Zaburi and Lemiyoni found in Monduli district as well as Imbibia and Engalaoni found in Arusha rural district close to Monduli forest reserve as explained early. Three respondents (MSPs) were local midwifes, two traditional healers, and the rest were normal elders in the community and all of them mostly working with flora used in FS and TM. Their ages ranged from 30 to 97 years $($ mean $=66.90$ : $\mathrm{SD}=17.98)$. The knowledge held by respondents was recorded based on their preferences. Most frequently mentioned human ailments of public health importance around the area were also investigated with respect to the symptoms of the diseases as confirmed by their indigenous knowledge. Ailments of public health importance are diseases or conditions that are threat to public health and those can be identifiable on an individual or at a community level. 
Table 1: Demographic data of the MSPs in FS and TM in Monduli District, Arusha Region, 2021.

\begin{tabular}{|c|c|c|c|c|}
\hline Demographic data $(N=21)$ & \multicolumn{4}{|c|}{ Frequency $(\%)$} \\
\hline \multicolumn{5}{|l|}{ Gender } \\
\hline Male & & & & $15(71)$ \\
\hline Female & & & & $6(29)$ \\
\hline \multicolumn{5}{|l|}{ Education status } \\
\hline Non-formal & & & & $11(52)$ \\
\hline Basic reading and writing skills only (adult education) & & & & $3(14)$ \\
\hline Elementary school (STD I - IV/VII) & & & & $7(33)$ \\
\hline \multicolumn{5}{|l|}{ Ethnicity } \\
\hline Maasai & & & & $21(100)$ \\
\hline \multicolumn{5}{|l|}{ Occupation of MSPs } \\
\hline Agro-pastoralist (AGP) & & & & $18(86)$ \\
\hline Agro-zerograzing (AGZ) & & & & $3(14)$ \\
\hline Traditional Healer (TH) & & & & $2(10)$ \\
\hline Traditional Midwife (TMW) & & & & $3(14)$ \\
\hline Years of Experience (range) & AGP & AGZ & TH & TMW \\
\hline$<10$ years (least experience was 8 years) & $1(5)$ & 0 & 0 & 0 \\
\hline $10-20$ years & $4(19)$ & 0 & 0 & 0 \\
\hline More than 20 years & $13(62)$ & $3(14)$ & $2(10)$ & $3(14)$ \\
\hline
\end{tabular}

\section{Ethnobotanical data collection}

Rigorous individual interviews and extended discussions with the MSPs, guided field walk, free listing and market survey were the main data collection methods used in this study. Bennett's Golden Rules for ethnobotanical fieldwork were followed to ensure effective interaction with MSPs. Standard pre-prepared questionnaires were used to record the information given by MSPs about the local name of the MP, the part (s) used, preparation methods, disease (s) treated, the route of delivery, possible side effects and antidotes used. Plant growth habitat, habit, conservation status, potential threats, and management prospects of the reported MPs were also included in the study interview guide. The checklist used was translated into the local language (Maasai), and the 
responses of the MSPs in the data collection tool. All interviews and discussion were conducted in Maasai or Swahili by the principal investigator with the assistance of a translator of Maasai language to Swahili or English and vice versa. Each MSPs was visited and interviewed two or three times to ensure consistency of the information provided. The local market survey was carried out at four open marketplaces (Ngaramtoni, Monduli, Makuyuni and Meserani) found in the study area (see figure 1). In the market survey name of the plant, part used and the purpose it was sold were recorded.

\section{Plant specimen collection and identification}

Following the records of ethnobotanical information, voucher specimens of the flora were collected from the wild (W), home garden (HG) and farms (FM) under the guidance of MSPs from June through August 2020 and end up in April, 2021. GPS was used to record data on geographical coordinates and altitude. The specimens were numbered and the Maasai name of the species were recorded, pressed, and properly dried in the field. Appropriate documentation was made with photographic pictures of the area and the mature individual plant at the site of collection. The identification of specimens was carried out using Flora of Tropical East Africa [23] by an assistance of the botanist and his team members at the National herbarium of Tanzania. Specimens with labels were finally deposited at the National Herbarium (TPRI) in Tanzania.

\section{Data Analysis}

Data analysis was carried out using both the classical ethnobotanical systematic investigation and a numerical quantitative approach in order to evaluate the importance of the mentioned plant species in the investigated area. The quantitative study was carried out by calculating the following ethnobotanical indices:

Use categories. Plants used in the study area were classified into categories by adopting the method developed by cook [24]. Plants were broadly classified into different use categories which included: medicinal, food, food processing or storage, and other uses based on the use reports in the study area. Each time a plant was mentioned as "used" was considered as one "use report". If one informant used a plant to treat more than one disease or for more than one use in the category it was considered as a single use report [24] 
Use value (UV) index. The index is a quantitative measure which facilitates evaluation of the relative importance of each species known locally based on its relative use among informants [2426]:

$$
\mathrm{UV}=\frac{\sum U_{\mathrm{i}}}{\mathrm{N}}
$$

where $U_{\mathrm{i}}$ represents the number of use reports cited by each informant for a given species and $\mathrm{N}$ denotes the total number of informants. However, the use value does not distinguish between single or multiple use purpose of a plant species. Use values are high when there are many use reports for a plant species, signify that the species is important, and approach zero (0) when there are few reports related to its uses.

Informant consensus factor (ICF). This measure was used to test the homogeneity of knowledge among informants [24,27]:

$$
\mathrm{ICF}=\frac{N_{\mathrm{ur}}-N_{\mathrm{s}}}{N_{\mathrm{ur}}-1}
$$

where $N_{\text {ur }}$ denotes the number of use reports for a particular use category and $N_{\mathrm{s}}$ denotes the number of species or taxa used for a particular use category by all informants. Informant consensus factor (ICF) values are low, close to zero (0) if plants are chosen randomly or if there is no exchange of information about their use among informants or there is disagreement among the informants which may be due to having different experiences and keeping information with strict secrecy [24,27]. Informant consensus factor (ICF) approach to one (1) when there is well-defined selection criterion in the community and/or if there is information exchange between informants or when there is only one or few species reported by the majority of informants [24,27].

Fidelity level (FL). This measure provide the ratio of informants who independently reported their use of a species for the same major purpose to the total number of informants who mentioned the species for any use [27]:

$$
\text { FL }(\%)=\frac{N_{p}}{N} \times 100
$$


Where $N_{p}$ is the number of informants that claim the use of a plant species for a particular purpose (e.g., treating a particular disease), and $N$ is the total number of informants that use the plant species for any use such as treating a particular disease [27].

Relative frequency of citation (RFC). The index of relative frequency of citation (RFC) was determined by employing the following formula:

$$
\mathrm{RFC}=\frac{\mathrm{FC}}{\mathrm{N}}
$$

where FC is the number of informants reporting use of a particular species and $\mathrm{N}$ is the total number of informants [25].

Specific Relative Frequency of Citation $\left(\mathbf{R F C}_{s}\right)$. This study ought to determine and compare relative importance of plant species used for the same specific purpose in the study area; therefore, the $\mathbf{R F C}_{\boldsymbol{s}}$ was computed by employing the following formula:

$$
\mathrm{RFC}_{S}=\mathrm{FL} \times \mathrm{RFC}=\frac{N_{p}}{N} \times \frac{\mathrm{FC}}{\mathrm{N}}
$$

Note: $\quad N=$ FC

Most reliable flora used in FS and TM considered to be effective for the common human illness or health condition or role performed were identified based on the agreement among the MSPs using the free list data that show degree of consensus among them.

\section{Results}

\section{Flora reported by MSPs in indigenous FS and TM}

Results provide the following information for each species: botanical family, scientific name, vernacular name, habitat, habit, part used, route of administration, use value, relative frequency of citation, preparation and application, and illness/disease condition treated or role performed (Table 2). This study documented one hundred and one (101) plant species distributed in 47 families and 83 genera in the study area (Table 2). Twenty-two (22) families were represented by two (2) or more flora species, whereas twenty-five (25) families were represented by only single species each (Table 2). The most represented family were Euphorbiaceae and Fabaceae with 8 species each; 
followed by Solanaceae (6 species); Boraginaceae, Rhamnaceae, Rutaceae and Verbenaceae (5 species each); Anacardiaceae, (4 species); and the remaining families each represented by at most three (3) species (Table 2). Most of the ethnobotanical species constituted trees (T) which accounted $45.19 \%$ (47 species), followed by shrubs ( $\mathrm{Sb}$ ) 24.04\% (25 species) (Fig. 1). Most of the species $(88.79 \%)$ were sourced from the wild environment, followed by home gardens (HG) $7.48 \%$ (Fig. 2).

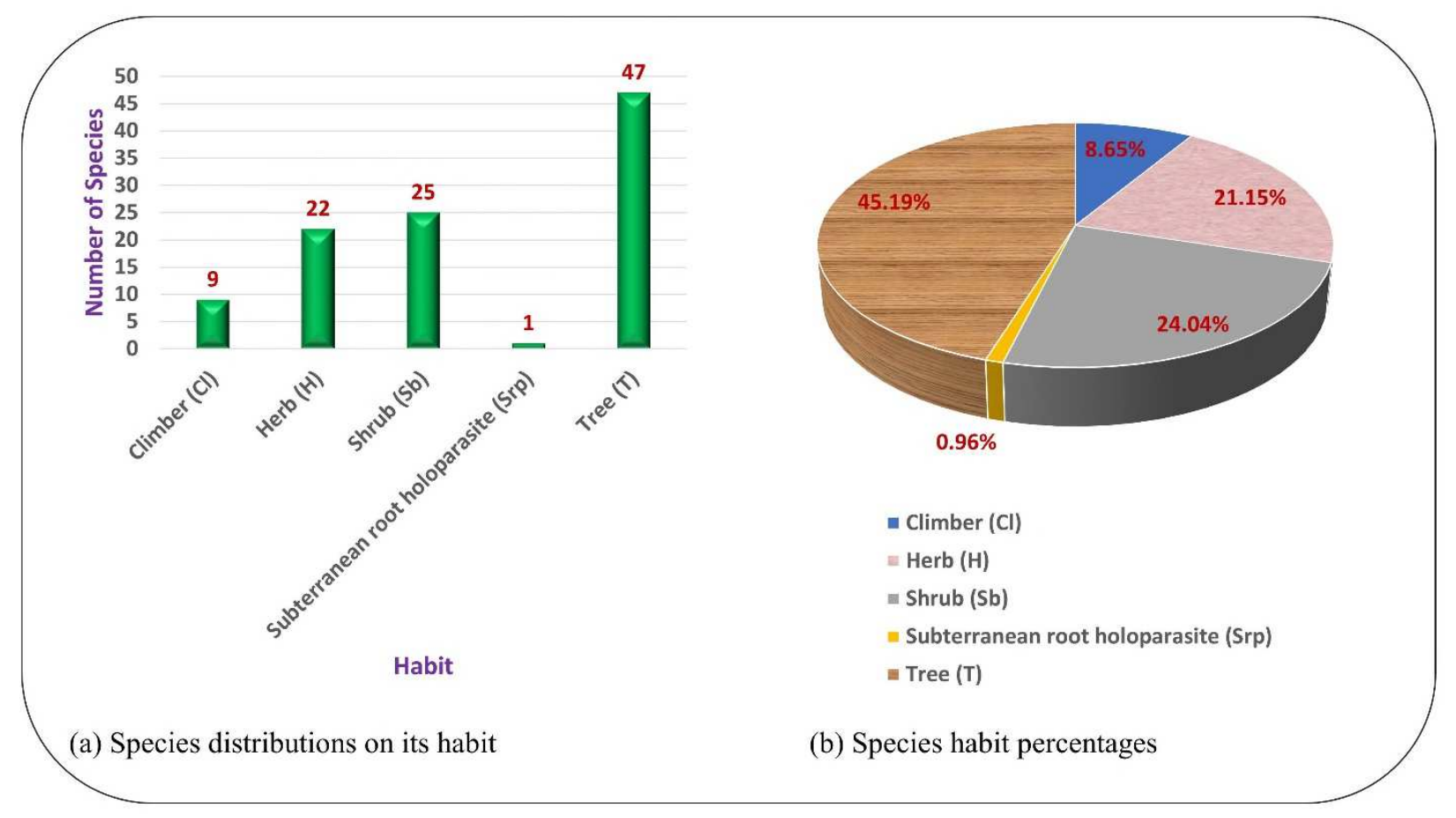

Figure 1 Species distributions (a) and percentages (b) on habit of flora used in the study area 


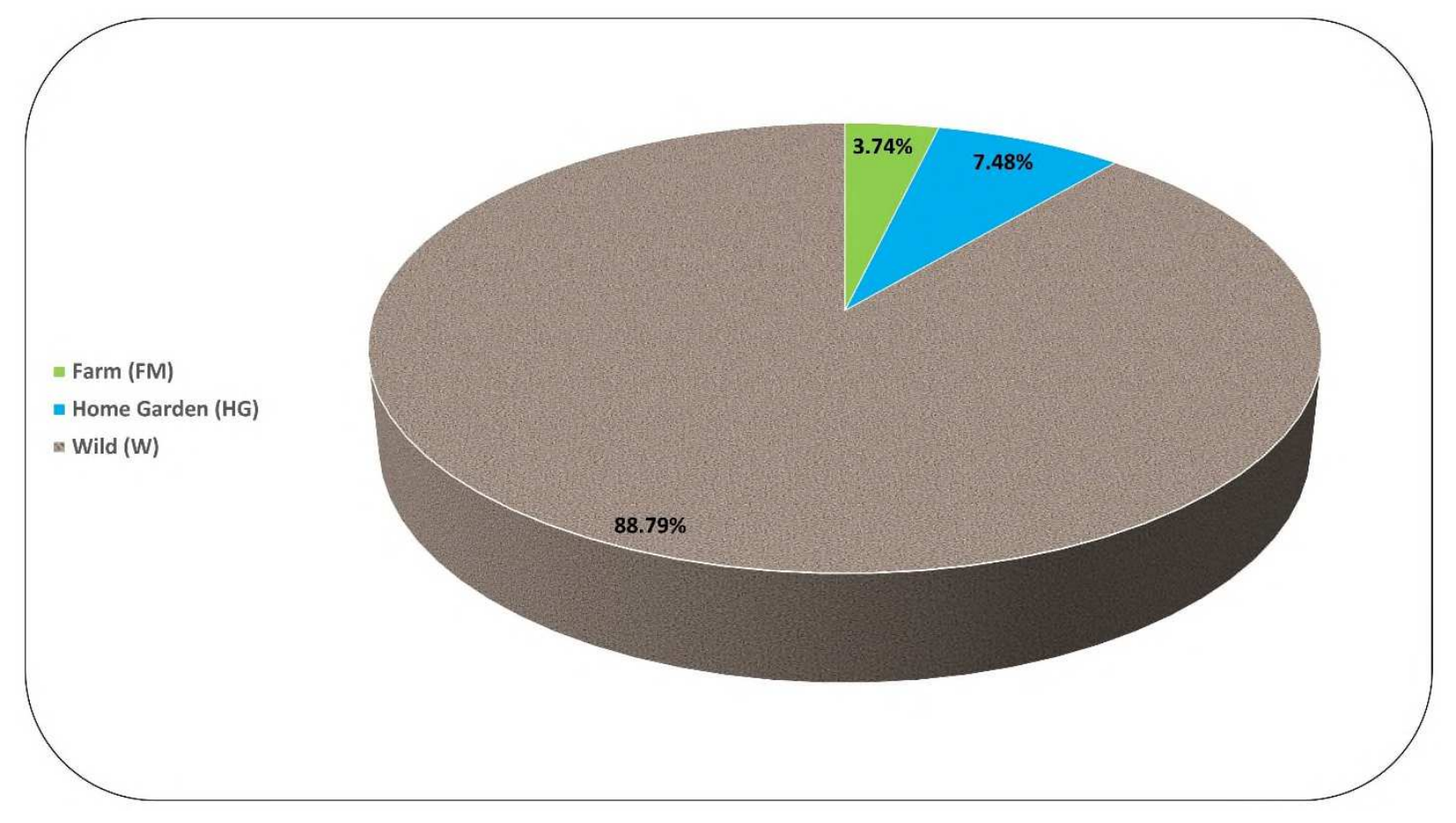

Figure 2 Habitat percentages of flora used in the study area

The species recorded in this study have different uses; whereas, medicinal uses accounted for $53.69 \%$ ( 80 species) at ICF of 0.71 , followed by food processing or storage accounted for $21.48 \%$ (32 species) at ICF of 0.82 , food source accounted for $19.46 \%$ (29 species) at ICF of 0.79 , and other additional uses such as glue, soap, axe handle, veterinary and ritual purpose, accounted for $5.37 \%$ ( 8 species) at ICF of 0.56 (Fig. 3 and Table 2). Most of the species used, theirs plants parts have more than one uses which were varying from plant to plant (Table 2).

The most commonly used plants for food sources included Vangueria infausta $(\mathrm{FL}=1.00 ; \mathrm{RFC}=$ $81 \%)$; followed by Ximenia caffra and Dovyalis abyssinica each with $(\mathrm{FL}=1.00 ; \mathrm{RFC}=52 \%)$ and in all cases fruits were used. Furthermore, it was found that $58.62 \%$ (17 species) of the plants used as food sources were also used for medicinal purpose (Table 2). Some of which shared common parts for food and medicinal uses while for others, their parts were different for the uses (Table 2). Ximenia caffra apart from being a food source plant, it barks and roots are used as a medicine for treating various health conditions including joints' pain (Table 2).

Furthermore, food processing or storage in this study, included cleaning and preventing contamination, stirring, preservation, providing taste, appetite, odor, flavor, color or viscosity of 
the food, dissolving fats or coagulate animal blood, holding cooked food, grinding food staffs and storing food (Table 2). In this study it was found that the most commonly used plant for food processing or storage was Lagenaria siceraria (storing liquid food) with FL of 1.00 and RFC = $100 \%$; followed by Olea europaea subsp. Africana which is used for fumigating storage container (calabash), preservation, providing odor and taste of liquid foods $(\mathrm{FL}=1.00 ; \mathrm{RFC}=100)$. In addition: Lippia javanica $(\mathrm{FL}=1.00 ; \mathrm{RFC}=0.57)$; Grewia bicolor $(\mathrm{FL}=0.75 ; \mathrm{RFC}=57 \%)$; Ficus thonningii $(\mathrm{FL}=1.00 ; \mathrm{RFC}=52 \%)$; and Clausena anisata $(\mathrm{FL}=0.80 ; \mathrm{RFC}=48 \%)$ were also frequently used for their roles (Table 2). Moreover, it was found that 56. 25\% (18 species) of the plants used for food processing or storage materials were also used for medicinal purpose (Table 2). Thirteen (13) of these plants shared common parts for medicinal and food processing uses while the remaining species their parts were different for the uses (Table 2). Among these plants the following species namely, Acacia nilotica, Combretum zeyheri, Cordia sp, Croton dichogamus, Cyphostemma subciliatum, Ocimum gratissimum, Piper capense, and Ximenia caffra shared the common parts for food processing and treatment of various health conditions including joints' pain and inflammation, 'OSUPETAI' and 'OLGILA' (Table 2).

Still, this study recorded some plants with highest use value. Withania somnifera (L.) Dunal (Olesayet) had the highest UV of 2.67 followed by Lagenaria siceraria (Molina) Standl (Oltulet/engotii) with UV of 2.48, and Olea europaea subsp. Africana (Mill.) P. S. Green (Oloirien) with UV of 1.95 (Table 2). Use value of the remaining plants are detailed in table 2. 


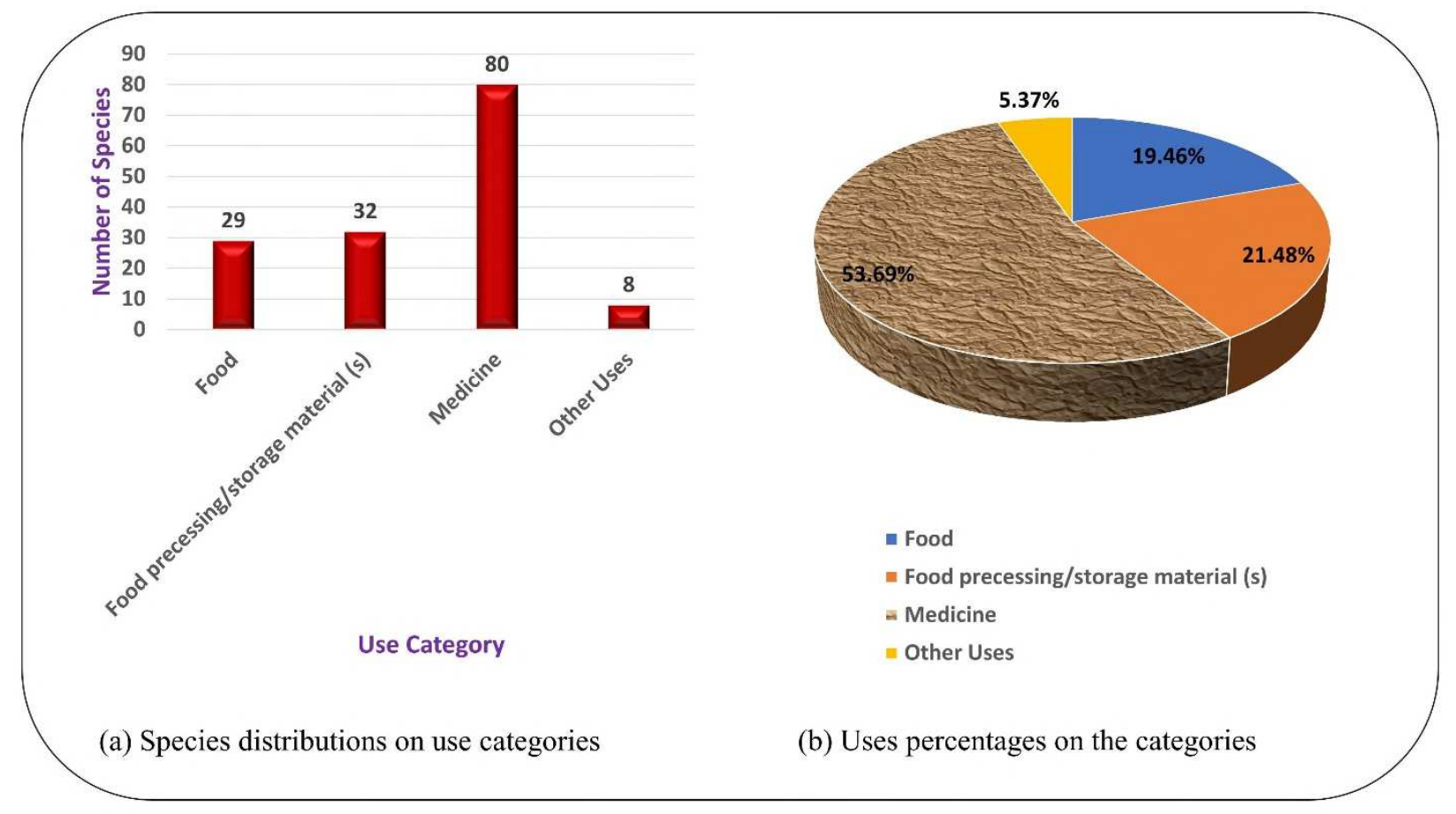

Figure 3 Species distributions (a) and uses percentages (b) on categories of uses for flora in the study area

\section{Degree of MSPs' agreement on flora used in the study area}

Selection of flora used in FS and TM by the MSPs depends profoundly on their prior gaining of knowledge from well-organized training in meat eating festival 'orpul', elders, parents or cross communication with other MSPs in the community. Furthermore, MSPs apprehended that historical narratives or experiences were taken into account in choosing the best or the most effective flora in their FS and TM to avoid the plants that are reported to have serious side effects or consequence to human life.

This study showed that some plants such as Olea europaea subsp. Africana and Lagenaria siceraria were used by all $(\mathrm{RFC}=100 \%)$ of the MSPs for food processing (preservation and flavoring agent) and storage purpose respectively, followed by Vangueria infausta used by $81 \%$ of the MSPs as the most commonly used food source (Table 2). In addition, evading plants with side effects or negative consequences to human life was evident in the choice of Albizia anthelmintica (Emukutan). Existence of two species of Emukutan was reported. One Emukutan ('Orong'ujinia' in Maasai / 'Fisi' in Swahili) which has spots on the back and its backs is brittle, 
kills human instantly when eaten and always is fenced with thorns as a sign of killing history. The other normal Emukutan (Albizia anthelmintica) with smooth (no spots) and non-brittle back which can be made into a rope, is used for medicinal purpose as reported in this study. Furthermore, both Albizia anthelmintica and Embelia schimperi (Olchani onyokie) with FL of 0.36 and 0.90 respectively, have history or experience of inducing abortion in pregnant women while Embelia schimperi with FL of 0.90 can further induce excess menstrual flow and causes infertility in women; thus, care is taken in using the MPs by considering pregnancy and menstrual cycle or menopause status in women to avoid the side effects.

Computation of ICF values has shown varying degree of agreement among informants on illness treated, health conditions induced or roles performed by the flora used in the study area. Two (2) floral species inducing 'abortion or excess menstrual flow' (Table 2) had the highest ICF of 0.90 followed by those (6 species) used to treat intestinal worms or parasites (Table 2) with ICF of 0.773 (Table 3). The remaining illness or health conditions are detailed in Table 2 and Table 3.

Moreover, reports of other use categories showed that some flora (4 species) used for food preservation, taste and flavor (Table 2) had the highest ICF of 0.93 (Table 3) followed by those (2 species) used to stop thirst with ICF of 0.833 (Table 2 and Table 3) and those (32 species) used for food processing or storage purpose (Table 2) had ICF of 0.815 (Table 3). In addition, some flora (29 species) used as a source of food had ICF of 0.791 (Table 2 and Table 3). Likewise, some flora (8 species) used for other additional uses such as veterinary, gluing materials and canning stick had ICF of 0.563 (Table $2 \&$ Table 3 ).

\section{Diseases treated and Treatment approaches managed by MPs of the study area}

This study recorded more than 38 different human illness or health conditions (Table2 \& Table 3) treated or induced by MPs used in the study (Table 2). The most prevalent diseases or health conditions managed by the MPs was intestinal worms or parasite (ICF $=0.77$ ); followed by increasing confidence or angriness ('MORI') and increasing libido, energy or strength each with $(\mathrm{ICF}=0.71)$; inducing vomiting $(\mathrm{ICF}=0.69)$; and constipation or stomach gas, cough and food digestion each with ICF of 0.67 (Table 3). Besides, health conditions that are accounted for higher number of species used in their management included 'OSUPETAI'/ 'OLGILA' treated by 33 species (41.3\%) of the MPs with ICF of 0.58; followed by diuresis (cleanse kidney) induced by 32 
species $(40.0 \%)$ of MPs with ICF of 0.63 ; joints' pain and or inflammation treatment by 30 species (37.5\%) of MPs with ICF 0.52 (Table $2 \&$ Table 3 ).

On the other hand, the study recorded three (3) main approaches for treating the most common diseases. These included diuresis or frequent urination, which more often results into a white urine, an indicator for cleansing kidney as per respondents, the second was diarrhea while the third was vomiting. Diarrhea was induced by 13 species with ICF of 0.57 while vomiting was induced by 5 species with ICF of 0.69 .

The most frequently used MP in inducing diarrhea was Albizia anthelmintica $(\mathrm{FL}=0.91$; RCs $=$ 0.48). This was followed by Croton megalocarpus ( $\mathrm{FL}=1.00 ; \mathrm{RFC} s=0.19)$, and Rapanea melanophloeos $(\mathrm{FL}=0.5$; RFCs $=0.14)$. Albizia anthelmintica was used in treatment of stomach worms, malaria or fever, 'OSUPETAI', detoxify swallowed poison and increasing body heat (Table 2). Croton megalocarpus was used in treatment of stomach worms, 'OSUPETAI', joints and back pain (Table 2). Rapanea melanophloeos used for worms, 'OSUPETAI', gonorrhea, boil, pain and swelling on ankles or knee, and wounds treatments (Table 2).

Moreover, the most frequently used MP in inducing vomiting was Albizia anthelmintica $(\mathrm{FL}=$ 0.54; RFC $s=0.29)$, followed by Rumex usambarensis with $(\mathrm{FL}=0.80 ; \mathrm{RFC} s=0.19)$. Rumex usambarensis is used to detoxify food poisoning or swallowed poison, treat 'OSUPETAI', stomach ulcers, infertility and clean uterus (Table 2).

Furthermore, this study showed that some of the disease conditions are understood, defined and explained in a unique way by MSPs in their indigenous health care system. This indigenous health care system of the study area is apparent from the local vocabularies applied to the diseases or health conditions described by the respondents. For instance, 'OSUPETAI' with RFC of $95.2 \%$ is the health conditions characterized by the following symptoms with their FL (\%) value in the bracket: swelling on a skin with an opening and discharging pus, boil (10\%); swelling and or pain on legs $(15 \%)$, ankles $(10 \%)$ knee (30\%) tooth gum (5\%), and nipples (5\%); pain on waist (30\%), joints (10\%), muscles (5\%), back (35\%); body tiredness or weakness (25\%); gonorrhea, obstructed urination associated with pain and discharge of blood and pus from the urinary tracts, as well as waist pain (47.6\%); edema, a swollen part when pressed retain dimples or pits (20\%); sudden and severe pain and warmth on ankle, finger and knee joint especially during the night $(5 \%)$; reduced 
libido (10\%); pain and coldness feeling on bones (10\%); tonsillitis (5\%); and headache on one side of the head in cold weather $(5 \%)$.

'OSUPETAI' is reported to be caused by the following with their FL value in the bracket: sexual intercourse (55\%) between a man and a woman which results in mixing blood between them; whereas, a condition for infection could be a virgin woman, a prostitute non-pregnant woman with a sperm deposit in her womb, or a woman in her menstrual cycle or a male infected with 'OSUPETAI'. In addition, it is also caused by urine of small worms ('Minyoo ya safura' in Swahili) in the body (10\%); drinking of soda or eating roast food or lack of physical exercise (10\%); eating food without taking herbs $(15 \%)$ or eating food without cleaning the body through diarrhea or frequent urination $(10 \%)$.

'OSUPETAI' is classified by the MSPs based on the part of the body affected or the effect of the disease. The following are the categories of 'OSUPETAI' with their FL values in the bracket: 'OSUPETAI' of the bones, 'loloik' in Maasai (30\%); muscles 'OSUPETAI' (15\%); joints' 'OSUPETAI' (15\%); and urinary tract or gonorrhea 'OSUPETAI' (45\%).

Equally, other health conditions included 'OLGILA' with RFC of 38.1\%. It is reported to be characterized by the following symptoms with their FL in the bracket: body weakness and pain on joints such as knee, fingers as well as pain of the back and waist (38.1\%). The disease is caused by the following: modern way of roasting meat which involve the use of salt and direct fire resulting into smoke and ashes on the meat (4.8\%); lack of exercise or eating without working, just sleeping (4.8\%); and coldness weather (4.8\%). In addition, 'ENAPORSESENI' is the health condition which in Swahili is referred to as 'ngiri' while in English is hernia, is characterized by stomach grumbling or pain on umbilical cord. Besides, 'OROROBI' is another health condition characterized by flue, cough and fever. Other common medicinal function or illness are detailed in the Table 2 and Table 3.

\section{Parts of the flora used by MSPs}

In this study it was found that various parts of the plants separately or in combination were used to treat particular illnesses or to perform specific roles (Table 2) as described by MSPs. Roots were the most commonly used part accounted for 55 species with $30.73 \%$ of uses and 213 use reports, 
followed by fruits accounted for 35 species with $19.55 \%$ of uses and 171 use reports (Fig. 4). Other parts are detailed in figure 4 and Table 2.

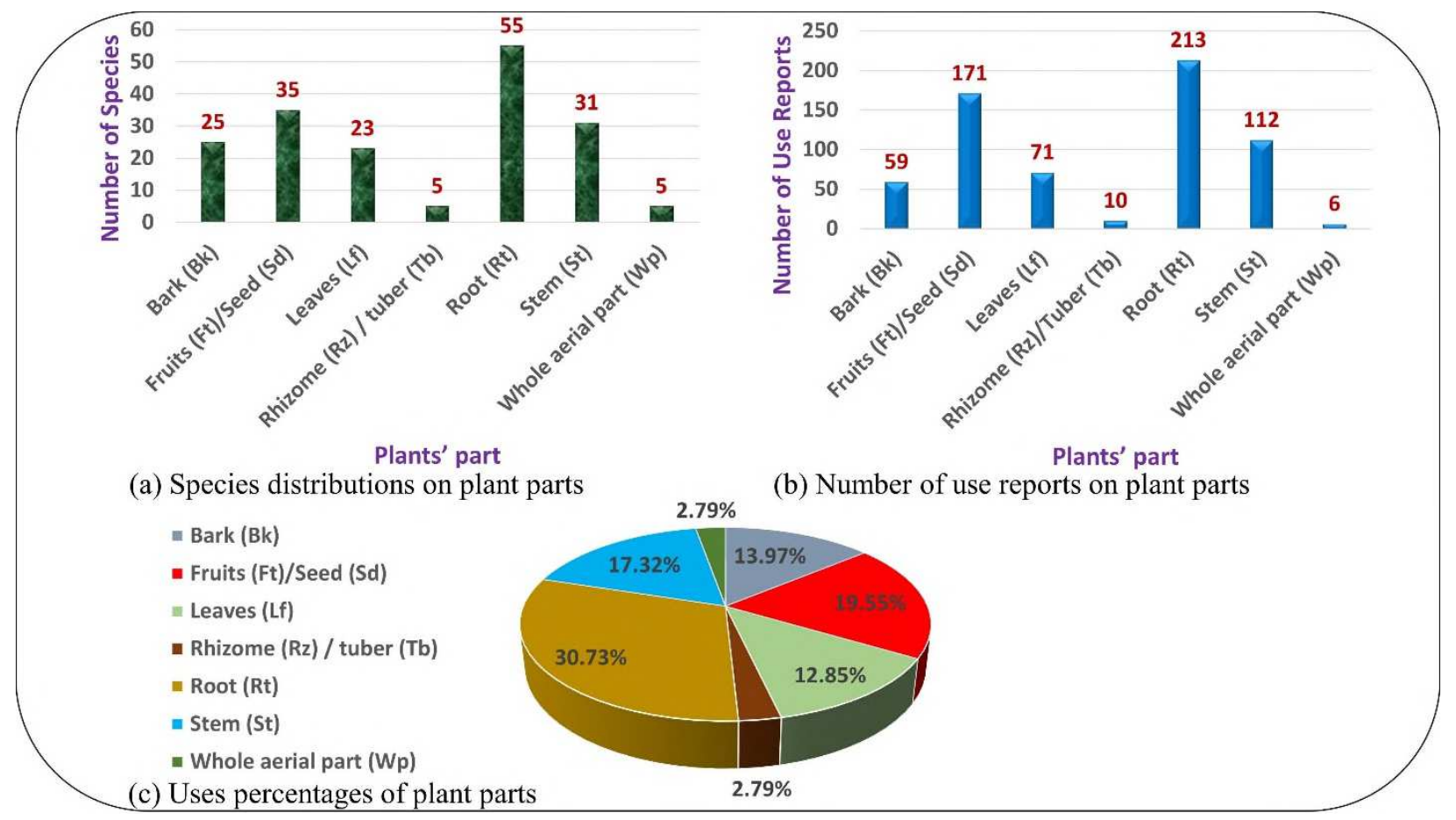

Figure 4 Species distributions (a), number of use reports (b) and usage percentages on parts of flora used in the study area

\section{Preparation and routes of delivery of flora used in Maasai FS and TMs}

Preparation of the flora used in Maasai FS and TMs was reported to involve decoction, infusion, squeezing, oozing, smoke or ashes, chewing and swallowing, beating on a body part particularly on the skin. The decoctions were used alone or mixed with other materials (medium) or mixed with other herbal decoctions. Materials (medium) mixed with the herbal decoctions included meat broth or stock, milk, melted tallow, clarified butter, blood, castor oil, honey and other plant parts such as Aloe sp roots. The decoction of the flora particularly MPs, when mixed with meat broth or stock, it is often in mixtures with other herbal decoction though a decoction for a single herb could be mixed alone with the meat broth or stock and drunk to realize its specific medicinal purpose. The decoction of the mixture of MPs when used alone or added into the medium such as meat broth or stock and honey was used to realize multiple medicinal roles, each performed by a specific components' MP. In addition, some herbal decoction was mixed with medium like meat broth or 
stock and milk to realize some roles such as dissolving fats, add taste, flavor, increasing viscosity of the mixture (Table 2). On the other hand, medium used in infusion preparation included cococola soda, table salt solution, fat, margarine, honey, sugar solution, meat broth or stock, milk, porridge, melted tallow or clarified butter, hot water or tea (Table 2). Mixing of herbal medicine with medium as explained above was reported to have advantages in balancing the strength or reducing side effects that mighty associate with the herbs, facilitating its diffusion into the body and increasing its efficacy in treating a disease or realizing targeted effect on the health condition. However, some of the herbs were used alone or in decoction without mixing with other medium especially when the herb is considered safe for such use condition.

The most common preparation was decoction in meat broth or stock accounted for 44 species (55\%) of MPs followed by herbal decoction alone accounted for 24 species (30\%) of MPs. Chewing and swallowing accounted for 35 species; whereas, 29 species (82.9\%) of the plant used as food sources of which 17 species $(58.6 \%)$ of them had both medicinal and food uses. The remaining preparations are detailed in (Fig. 5 \& Table 2). The most common route of delivery for the preparations was oral accounted for 92 species $(85.19 \%)$, followed by nasal 8 species $(7.41 \%$ each) see (Fig. 6). Some of species were found to be used, through more than one route of delivery (Table 2).

Dosage of the therapy was administered by MSPs based on sex, age, fitness status, health history, duration of the sickness, presence or absence of pregnancy and other related factors. For instance, Albizia anthelmintica and Embelia schimperi preparations were reported to cause abortion in pregnant women; thus, pregnant women should avoid their uses. In addition, Embelia schimperi preparations were reported to induce excess menstrual flow; thus, women before menopause should not use the medicine. Furthermore, in case of overdose or excess diarrhea induced by Albizia anthelmintica preparation, porridge and fresh milk mixture were drunk to stop diarrhea and restore the lost energy. The reported dosage measurements included drops, palm, tea spoon, table spoon, 'Molel' ( $\left.1 \frac{1}{4} \mathrm{~L}\right)$, 'Neing'asha or Laiser' $(1 / 2 \mathrm{~L})$, 'Leseri or Tumberi' $(1 \mathrm{~L})$ and any locally accessible measuring material. The amount of MP drunk, chewed and swallowed, eaten, applied externally and the duration of the therapy application were varying among the MSPs. 


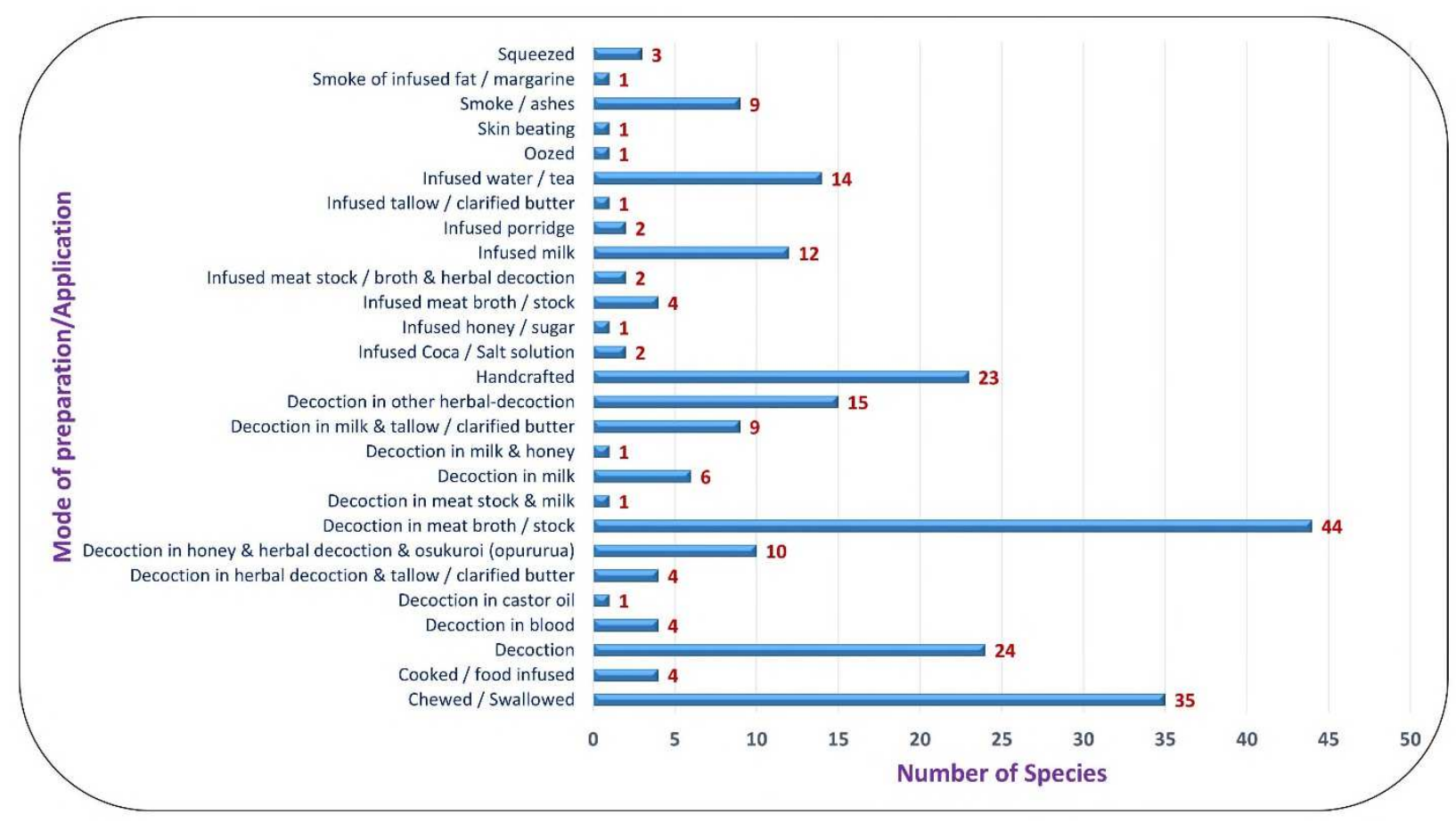

Figure 5 Species distributions on mode of preparations or application of flora used in FS and TM by MSPs in the study area

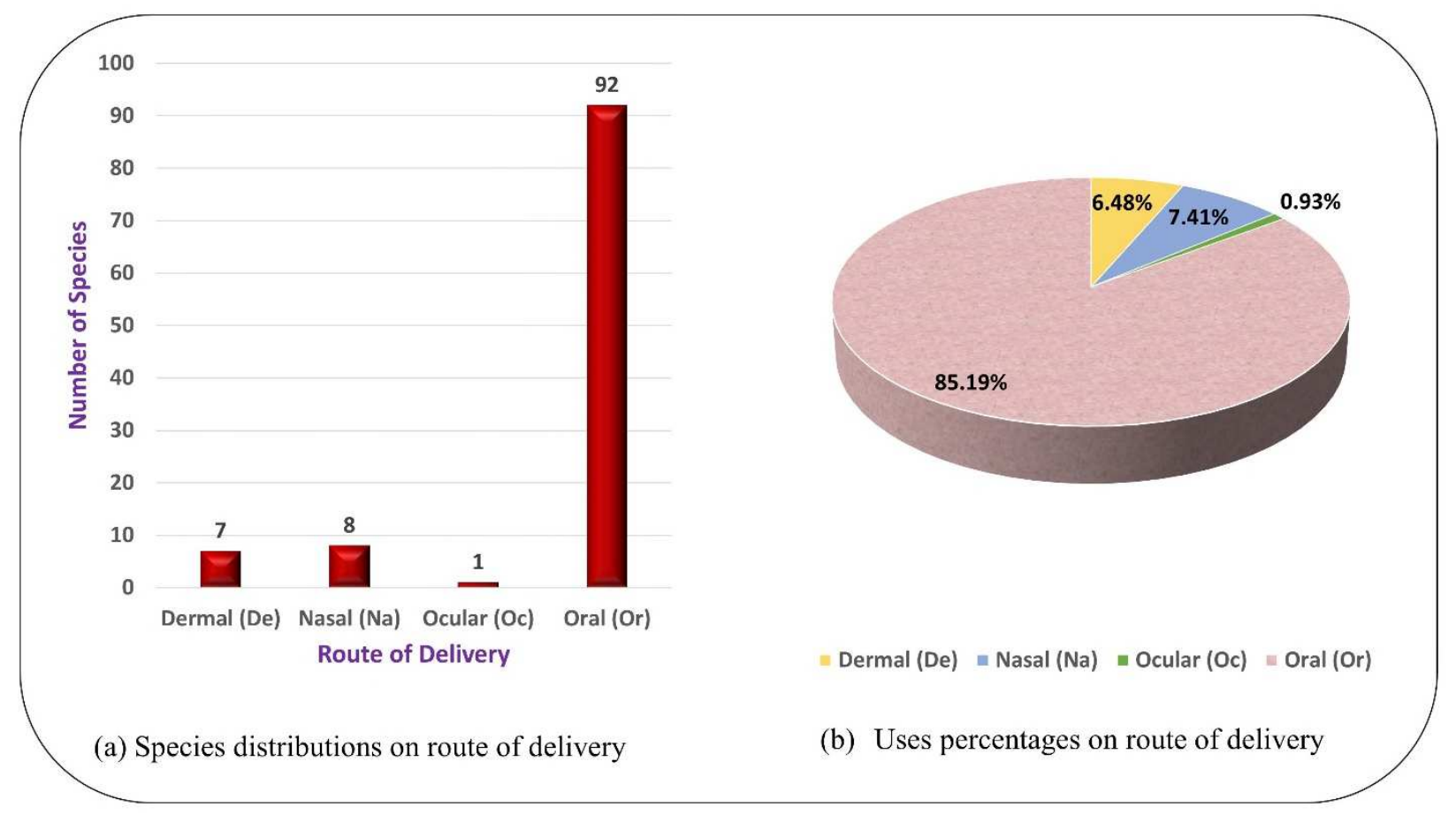

Figure 6 Species distributions (a) and usage percentages (b) on route of delivery of flora used in FS and TM by MSPs in the study area 
Table 2 Description on the habitat, habit, part used, route of administration, use value, relative frequency of citation, mode of preparation and human illness treated or role performed by flora used by MSPs in Monduli Districts, Arusha, 2021

\begin{tabular}{|c|c|c|c|c|c|c|c|c|c|c|c|}
\hline Family & $\begin{array}{l}\text { Scientific } \\
\text { name }\end{array}$ & $\begin{array}{l}\text { Vernacular } \\
\text { name } \\
\text { (Maasai) }\end{array}$ & Habitat & Habit & PU & RA & UV & RFC & Preparation and application & $\begin{array}{l}\text { Illness or disease condition treated / } \\
\text { role performed }\end{array}$ & $\begin{array}{l}\text { Collection } \\
\text { No. }\end{array}$ \\
\hline Amaranthaceae & $\begin{array}{l}\text { Cyathula } \\
\text { orthocantha } \\
\text { Schinz }\end{array}$ & Olaisai & W & $\mathrm{H}$ & Rt & Or & 0.05 & 5 & Fresh or dry roots is boiled and the decoction is drunk & Joints (knee) pain & RPC086 \\
\hline \multirow[t]{4}{*}{ Anacardiaceae } & $\begin{array}{l}\text { Lannea } \\
\text { schweinfurthii } \\
\text { Engl. }\end{array}$ & Orupande & w & T & Bk & Or & 0.29 & 10 & $\begin{array}{l}\text { Bark powder is decocted and mixed with milk \& animal } \\
\text { tallow (fats)/clarified butter and drunk } \\
\text { Milk and animal tallow/clarified butter mixture is infused } \\
\text { with the bark powder and drunk }\end{array}$ & $\begin{array}{l}\text { Clean uterus, reliefs uterus pain, stops } \\
\text { excess menstrual flow, stop bleeding \& } \\
\text { abortion in young pregnancy. }\end{array}$ & RPC059 \\
\hline & $\begin{array}{l}\text { Ozoroa insignis } \\
\text { subsp. } \\
\text { Reticulata }\end{array}$ & Olokinonoi & w & T & St & & 0.10 & 10 & Stem is crafted or curved into a stirrer ('orkipire') & Stirring liquid food & RPCO96 \\
\hline & $\begin{array}{l}\text { Rhus vulgaris } \\
\text { Meikle }\end{array}$ & Olmusigiyoi & w & $\mathrm{Sb}$ & FBRt & Or & 0.67 & 43 & $\begin{array}{l}\text { Fruit is chewed and swallowed } \\
\text { Bark or roots' decoction is mixed with meat broth/stock } \\
\text { and drunk. } \\
\text { Tea or fresh milk is infused with roots' powder and drunk }\end{array}$ & $\begin{array}{l}\text { Source of food } \\
\text { Joins a broken bone and cleanse kidney } \\
\text { (diuretic) }\end{array}$ & RPC036 \\
\hline & $\begin{array}{l}\text { Sclerocarya } \\
\text { birrea subsp. } \\
\text { multifoliolata } \\
\text { (Engl.) } \\
\text { Kokwaro }\end{array}$ & Ormang'uai & w & T & FSBk & Or & 0.76 & 43 & $\begin{array}{l}\text { Fruit is chewed and soft part is swallowed or the seed is } \\
\text { broken and oily nut is eaten } \\
\text { Stem is crafted /curved into a mortar ('engiuri') } \\
\text { Dry or fresh bark is boiled in water and the decoction is } \\
\text { drunk to the baby cow }\end{array}$ & $\begin{array}{l}\text { Source of food and produces alcohol. } \\
\text { Excess fruits cause alcoholism, diarrhea, } \\
\text { dizziness, vomiting or weaken joints } \\
\text { Grinds food staffs or herbal medicine } \\
\text { Sickness in baby cow }\end{array}$ & $\mathrm{RPC070}$ \\
\hline \multirow[t]{2}{*}{ Apocynaceae } & $\begin{array}{l}\text { Carissa } \\
\text { spinarum L }\end{array}$ & Olamuriaki & w & $\mathrm{Sb}$ & FRt & Or & 0.86 & 29 & $\begin{array}{l}\text { Fruit is chewed and swallowed } \\
\text { Roots' decoction is mixed with meat broth/stock and } \\
\text { drunk }\end{array}$ & $\begin{array}{l}\text { Source of food } \\
\text { Diuretic/cleanse kidney } \\
\text { Gonorrhea, bone pain, raises body } \\
\text { temperature \& immunity }\end{array}$ & RPC052 \\
\hline & $\begin{array}{l}\text { Tabernaemont } \\
\text { ana pachysiph } \\
\text { on Stapf }\end{array}$ & $\begin{array}{l}\text { Ormurasha / } \\
\text { Ormuraha }\end{array}$ & w & $T$ & Rt & Or & 0.19 & 5 & $\begin{array}{l}\text { Roots' decoction is mixed with meat broth/stock and } \\
\text { drunk }\end{array}$ & $\begin{array}{l}\text { Joints pain, boil/swelling } \\
\text { Diuretic/cleanse kidney, increases body } \\
\text { energy }\end{array}$ & RPC051 \\
\hline
\end{tabular}


Table 2 Description on the habitat, habit, part used, route of administration, use value, relative frequency of citation, mode of preparation and human illness treated or role performed by flora used by MSPs in Monduli Districts, Arusha, 2021 (continued)

\begin{tabular}{|c|c|c|c|c|c|c|c|c|c|c|c|}
\hline Family & $\begin{array}{l}\text { Scientific } \\
\text { name }\end{array}$ & $\begin{array}{l}\text { Vernacular } \\
\text { name (Maasai) }\end{array}$ & Habitat & Habit & PU & RA & UV & RFC & Preparation and application & $\begin{array}{l}\text { Illness or disease condition treated / } \\
\text { role performed }\end{array}$ & $\begin{array}{l}\text { Collection } \\
\text { No. }\end{array}$ \\
\hline Asclepiadaceae & $\begin{array}{l}\text { Secamone } \\
\text { parvifolia } \\
\text { (Oliv.) Bull. }\end{array}$ & osinandei & W & $\mathrm{Cl}$ & Rt & Or & 0.10 & 5 & $\begin{array}{l}\text { Fresh or dry root is boiled in water and the formed } \\
\text { decoction is mixed with fresh milk \& tallow/clarified } \\
\text { butter and drunk }\end{array}$ & Clean uterus, reliefs womb/uterus pain & RPC006 \\
\hline Asparagaceae & $\begin{array}{l}\text { Asparagus } \\
\text { setaceus } \\
\text { (Kunth) Jessop }\end{array}$ & Embere papa & w & $\mathrm{H}$ & Rt & Or & 0.19 & 14 & $\begin{array}{l}\text { Fresh (preferred) or dry root is chewed or its } \\
\text { decoction is mixed with meat broth/stock and drunk } \\
\text { Roots' decoction is mixed with honey and decoction } \\
\text { of Hydnora abyssinica rhizomes \& Tragia ukambensis } \\
\text { roots }\end{array}$ & $\begin{array}{l}\text { Causes erection / increases libido } \\
\text { pressure and diabetes }\end{array}$ & RPC004 \\
\hline \multirow[t]{3}{*}{ Asteraceae } & $\begin{array}{l}\text { Dicoma } \\
\text { tomentosa } \\
\text { Cass. }\end{array}$ & $\begin{array}{l}\text { Olchani } \\
\text { Iolasurai }\end{array}$ & w & H & Wp & $\begin{array}{l}\text { De/ } \\
\text { Or }\end{array}$ & 0.05 & 5 & $\begin{array}{l}\text { Dry aerial part is roasted on a hot sheet pan then } \\
\text { grinded into powder which is applied on small } \\
\text { bleeding cuts made on either side of snake bite area } \\
\text { along the blood flow direction. } \\
\text { The formed powder is also mixed with water and } \\
\text { drunk }\end{array}$ & $\begin{array}{l}\text { Detoxify snake poison in human and } \\
\text { animal (e.g. cow) }\end{array}$ & RPC083 \\
\hline & $\begin{array}{l}\text { Sphaeranthus } \\
\text { bullatus Mattf. }\end{array}$ & $\begin{array}{l}\text { Orkipire } \\
\text { lekima }\end{array}$ & w & $\mathrm{H}$ & LRzWp & Or & 0.05 & 5 & $\begin{array}{l}\text { Fresh leaves and rhizome or whole aerial part is } \\
\text { boiled in water and the formed decoction is mixed } \\
\text { with a fresh milk and drunk }\end{array}$ & $\begin{array}{l}\text { Increases Labor pain / facilitates } \\
\text { delivery process }\end{array}$ & RPC047 \\
\hline & $\begin{array}{l}\text { Vernonia } \\
\text { auriculifera } \\
\text { (Hiern) }\end{array}$ & Ormaduduu & w & $\mathrm{Sb}$ & Rt & Or & 0.38 & 10 & $\begin{array}{l}\text { Fresh or dry root is boiled in water and the formed } \\
\text { decoction is drunk }\end{array}$ & $\begin{array}{l}\text { Diuretic/cleanse kidney } \\
\text { Gonorrhea, pain of waist, legs or joints }\end{array}$ & RPC008 \\
\hline \multirow[t]{2}{*}{ Boraginaceae } & $\begin{array}{l}\text { Cordia } \\
\text { africana Lam. }\end{array}$ & Ormuringiringa & w & $\mathrm{T}$ & SBK & $\begin{array}{l}\text { De/ } \\
\text { Or }\end{array}$ & 0.33 & 14 & $\begin{array}{l}\text { Bark decoction is mixed with decoction of Lippia } \\
\text { kituiensis root \& Chenopodium schraderianum leaves } \\
\text { then drunk and steamed on the body, or mixed with } \\
\text { chicken broth / blood and drunk }\end{array}$ & Measles and 'OSUPETAI' & $\mathrm{RPCO} 42$ \\
\hline & & & & & & & & & Stem is crafted or curved into a mortar ('engiuri') & Grinds food staffs or herbal medicines & \\
\hline
\end{tabular}


Table 2 Description on the habitat, habit, part used, route of administration, use value, relative frequency of citation, mode of preparation and human illness treated or role performed by flora used by MSPs in Monduli Districts, Arusha, 2021 (continued)

\begin{tabular}{|c|c|c|c|c|c|c|c|c|c|c|c|}
\hline Family & Scientific name & $\begin{array}{l}\text { Vernacular } \\
\text { name } \\
\text { (Maasai) }\end{array}$ & Habitat & Habit & PU & RA & UV & RFC & Preparation and application & $\begin{array}{l}\text { Illness or disease condition treated / role } \\
\text { performed }\end{array}$ & $\begin{array}{l}\text { Collection } \\
\text { No. }\end{array}$ \\
\hline \multirow[t]{12}{*}{ Boraginaceae } & $\begin{array}{l}\text { Cordia monoica } \\
\text { Roxb }\end{array}$ & Oseki & w & $T$ & LFSBRt & $\begin{array}{l}\mathrm{Na} / \\
\text { Or }\end{array}$ & 0.67 & 38 & $\begin{array}{l}\text { Fresh leaves are crafted or made into a mat } \\
\text { ('enaraa') or used to squeeze coagulated blood }\end{array}$ & $\begin{array}{l}\text { Hold meat / animal in a slaughtering process, } \\
\text { dissolve coagulated blood }\end{array}$ & RPC048 \\
\hline & & & & & & & & & $\begin{array}{l}\text { Fruits is chewed and swallowed or made into a } \\
\text { juice and drunk }\end{array}$ & Source of food & \\
\hline & & & & & & & & & $\begin{array}{l}\text { A dry stem piece is burn into a smoke/ash and } \\
\text { spread into the storage container (calabash) }\end{array}$ & Food preservation, taste/flavor & \\
\hline & & & & & & & & & $\begin{array}{l}\text { Stem is crafted or curved into sharp end stick } \\
\text { ('orjibet'), pierced into meat pieces then erect } \\
\text { beside fire }\end{array}$ & Hold meat in the roasting process & \\
\hline & & & & & & & & & $\begin{array}{l}\text { Water is infused with bark powder or roots } \\
\text { decoction is mixed with fresh milk \& } \\
\text { tallow/clarified butter and drunk }\end{array}$ & Cleans uterus and reliefs menstruation pain & \\
\hline & Cordia monoica & Oldorko & W & $\mathrm{Sb}$ & FSt & $\mathrm{Na} /$ & 0.29 & 19 & & & RPC065 \\
\hline & & & & & & & & & $\begin{array}{l}\text { Stem is crafted or curved into sharp end stick } \\
\text { ('orjibet'), pierced into meat pieces then erected } \\
\text { beside fire }\end{array}$ & Hold meat in the roasting process & \\
\hline & & & & & & & & & $\begin{array}{l}\text { Dry stem pieces burn into a smoke/ash and } \\
\text { spread into the storage container (calabash) }\end{array}$ & Food preservation, taste/flavor & \\
\hline & $\begin{array}{l}\text { Cordia sinensis } \\
\text { Lam }\end{array}$ & Ingululu & w & $\mathrm{T}$ & $\mathrm{Ft}$ & Or & 0.05 & 5 & Fruit is chewed and soft part swallowed & Source of food & RPC091 \\
\hline & Cordia sp. & Olebalelon & W & $\mathrm{Sb}$ & SRt & Or & 0.71 & 24 & $\begin{array}{l}\text { Stem/roots' decoction is mixed with meat } \\
\text { broth/stock and drunk }\end{array}$ & $\begin{array}{l}\text { Pneumonia/chest pain and clean uterus } \\
\text { Diuretic/cleanse kidney }\end{array}$ & RPC082 \\
\hline & & & & & & & & & & 'OSUPETAI' / 'OLGILA' & \\
\hline & & & & & & & & & & $\begin{array}{l}\text { Provide taste, smell \& viscosity to the meat } \\
\text { broth/stock, increases blood, increases } \\
\text { lactating mothers' milk, reliefs tiredness }\end{array}$ & \\
\hline Burseraceae & $\begin{array}{l}\text { Commiphora } \\
\text { africana A. Rich }\end{array}$ & Esilalei & w & T & St & & 0.19 & 19 & $\begin{array}{l}\text { Stem is curved into a stirrer ('orkipire') or mortar } \\
\text { ('engiuri') }\end{array}$ & $\begin{array}{l}\text { Stirring liquid food, grinding food staffs or } \\
\text { herbal medicines }\end{array}$ & RPC097 \\
\hline
\end{tabular}


Table 2 Description on the habitat, habit, part used, route of administration, use value, relative frequency of citation, mode of preparation and human illness treated or role performed by flora used by MSPs in Monduli Districts, Arusha, 2021 (continued)

\begin{tabular}{|c|c|c|c|c|c|c|c|c|c|c|c|}
\hline Family & $\begin{array}{l}\text { Scientific } \\
\text { name }\end{array}$ & $\begin{array}{l}\text { Vernacular } \\
\text { name (Maasai) }\end{array}$ & Habitat & Habit & PU & RA & UV & RFC & Preparation and application & $\begin{array}{l}\text { Illness or disease condition treated / role } \\
\text { performed }\end{array}$ & $\begin{array}{l}\text { Collection } \\
\text { No. }\end{array}$ \\
\hline \multirow[t]{6}{*}{ Caesalpiniaceae } & \multirow{5}{*}{$\begin{array}{l}\text { Caesalpinia } \\
\text { decapetala } \\
\text { (Roth) Alston }\end{array}$} & \multirow[t]{5}{*}{ Ormashinga } & \multirow[t]{5}{*}{ W } & \multirow[t]{5}{*}{$\mathrm{Cl}$} & \multirow[t]{5}{*}{ LFSRt } & \multirow[t]{5}{*}{ Or } & \multirow[t]{5}{*}{0.71} & \multirow[t]{5}{*}{14} & $\begin{array}{l}\text { Fresh Leaves are chewed and the juice is } \\
\text { swallowed }\end{array}$ & Stomachache & \multirow[t]{5}{*}{ RPC019 } \\
\hline & & & & & & & & & $\begin{array}{l}\text { Fruit is squeeze into a juice and applied on } \\
\text { material joints }\end{array}$ & Glue & \\
\hline & & & & & & & & & $\begin{array}{l}\text { Stem decoction is mixed with meat broth/stock } \\
\text { and drunk }\end{array}$ & Hernia, Joints' pain \& swelling & \\
\hline & & & & & & & & & $\begin{array}{l}\text { Roots' decoction is mixed with meat broth/stock } \\
\text { and drunk }\end{array}$ & Hernia, Joints' pain \& swelling, back pain & \\
\hline & & & & & & & & & $\begin{array}{l}\text { Cooking banana and Lablab purpureus seeds } \\
\text { mixture is infused with root and eaten }\end{array}$ & $\begin{array}{l}\text { Induces diarrhea, treats constipation, } \\
\text { 'OSUPETAl' and clean pelvis }\end{array}$ & \\
\hline & $\begin{array}{l}\text { Senna } \\
\text { didymobotrya } \\
\text { (Fresen.) Irwin } \\
\text { \& Barneby }\end{array}$ & Ormapinu & W & $\mathrm{Sb}$ & Lf & Or & 0.14 & 5 & $\begin{array}{l}\text { Kitchen warm dried leaves is boiled in water and } \\
\text { the formed decoction is mixed with castral oil and } \\
\text { drunk }\end{array}$ & $\begin{array}{l}\text { Induces diarrhea, clean infected chest mucus, } \\
\text { treat 'OSUPETAI' }\end{array}$ & RPC015 \\
\hline \multirow[t]{2}{*}{ Capparaceae } & \multirow[t]{2}{*}{$\begin{array}{l}\text { Capparis } \\
\text { fascicularis DC. }\end{array}$} & \multirow[t]{2}{*}{$\begin{array}{l}\text { Ormakirutu / } \\
\text { Olaiturudia }\end{array}$} & \multirow[t]{2}{*}{ w } & \multirow[t]{2}{*}{$\mathrm{Sb}$} & \multirow[t]{2}{*}{ Rt } & $\begin{array}{l}\mathrm{Na} / \\
\text { Or }\end{array}$ & \multirow[t]{2}{*}{0.10} & \multirow[t]{2}{*}{10} & $\begin{array}{l}\text { Roots (white) decoction is mixed with Cyathula } \\
\text { orthocantha roots' decoction and drunk }\end{array}$ & Joints (knee) pain & \multirow[t]{2}{*}{ RPC092 } \\
\hline & & & & & & & & & $\begin{array}{l}\text { Dry root (red) is burn on fire and the smoke is } \\
\text { inhaled through nostrils }\end{array}$ & headache & \\
\hline Celastraceae & $\begin{array}{l}\text { Mystroxylon } \\
\text { aethiopicum } \\
\text { (Thunb.) Loes }\end{array}$ & Olodong'anayo & w & T & St & & 0.29 & 14 & Stem is curved into pestle ('emushi') & Grinds food staffs or herbal medicines & RPC029 \\
\hline \multirow[t]{2}{*}{ Chenopodiaceae } & $\begin{array}{l}\text { Chenopodium } \\
\text { schraderianum }\end{array}$ & Olekukunu & W & $\mathrm{H}$ & Lf & $\begin{array}{l}\text { De/ } \\
\text { Or }\end{array}$ & 0.67 & 19 & $\begin{array}{l}\text { Fresh leaves decoction is mixed with Solanum } \\
\text { aculeastrum roots' decoction and drunk }\end{array}$ & Diuretic/cleanse kidney & \multirow[t]{2}{*}{$\mathrm{RPC026}$} \\
\hline & $\begin{array}{l}\text { Roem. \& } \\
\text { Schult }\end{array}$ & & & & & & & & $\begin{array}{l}\text { Fresh leaves decoction is mixed with chicken broth } \\
\text { or blood, and decoction of Cordia africana barks \& } \\
\text { Lippia kituiensis roots then drunk }\end{array}$ & $\begin{array}{l}\text { Boil/swelling, joints' pain, tiredness, measles } \\
\text { and 'OSUPETAI' }\end{array}$ & \\
\hline
\end{tabular}


Table 2 Description on the habitat, habit, part used, route of administration, use value, relative frequency of citation, mode of preparation and human illness treated or role performed by flora used by MSPs in Monduli Districts, Arusha, 2021 (continued)

\begin{tabular}{|c|c|c|c|c|c|c|c|c|c|c|c|}
\hline Family & $\begin{array}{l}\text { Scientific } \\
\text { name }\end{array}$ & $\begin{array}{l}\text { Vernacular } \\
\text { name } \\
\text { (Maasai) }\end{array}$ & Habitat & Habit & PU & RA & UV & RFC & Preparation and application & $\begin{array}{l}\text { Illness or disease condition treated / role } \\
\text { performed }\end{array}$ & $\begin{array}{l}\text { Collection } \\
\text { No. }\end{array}$ \\
\hline \multirow[t]{3}{*}{ Combretaceae } & $\begin{array}{l}\text { Combretum } \\
\text { zeyheri Sond }\end{array}$ & $\begin{array}{l}\text { Ormaroroi- } \\
\text { oibor }\end{array}$ & W & $T$ & SBRt & Or & 0.95 & 24 & $\begin{array}{l}\text { Barks'/roots'/stem's decoction is mixed with meat } \\
\text { broth/stock and drunk, or milk tea is infused with } \\
\text { barks' powder and drunk }\end{array}$ & $\begin{array}{l}\text { Diuretic/ cleanse kidney } \\
\text { Muscles, joints (knee \& in step), back, } \\
\text { waist and chest pain, 'OSUPETAl' or } \\
\text { 'OLGILA', clean uterus }\end{array}$ & RPC098 \\
\hline & & & & & & & & & $\begin{array}{l}\text { Stem is curved into a sharp end stick ('orjibet'), } \\
\text { pierced through meat pieces and erected beside fire }\end{array}$ & Hold meat in roasting process & \\
\hline & $\begin{array}{l}\text { Terminalia } \\
\text { brownii Fresen }\end{array}$ & Orbukoi & W & T & Bk & Or & 0.19 & 5 & $\begin{array}{l}\text { Bark is boiled in water and the formed decoction is } \\
\text { drunk by human or to the cow }\end{array}$ & $\begin{array}{l}\text { Induces vomiting, antidote for a swallowed } \\
\text { poison and treat blood in urine / bilharzia } \\
\text { in either human or cow }\end{array}$ & RPC058 \\
\hline Cucurbitaceae & $\begin{array}{l}\text { Lagenaria } \\
\text { siceraria } \\
\text { (Molina) } \\
\text { Standl }\end{array}$ & $\begin{array}{l}\text { Oltulet } \\
\text { /engotii }\end{array}$ & HG & $\mathrm{Cl}$ & $\mathrm{Ft}$ & & 2.48 & 100 & Dry fruit is crafted or curved into a container & $\begin{array}{l}\text { Stores liquid foods: milk, 'oloshoro', } \\
\text { 'engitalolo', 'euji' or 'emberere' }\end{array}$ & RPC093 \\
\hline Ebenaceae & $\begin{array}{l}\text { Euclea } \\
\text { divinorum } \\
\text { (Hiern) }\end{array}$ & Osojo & w & T & Rt & Or & 0.14 & 5 & $\begin{array}{l}\text { Roots are boiled in water and the formed decoction is } \\
\text { mixed with fresh milk and tallow/clarified butter. }\end{array}$ & $\begin{array}{l}\text { Induces diarrhea, treats 'OSUPETAI' and } \\
\text { swelling from legs to the eyes }\end{array}$ & RPC010 \\
\hline \multirow[t]{4}{*}{ Euphorbiaceae } & $\begin{array}{l}\text { Clutia } \\
\text { abyssinica } \\
\text { Jaub. \& Spach }\end{array}$ & $\begin{array}{l}\text { Enginyamasa } \\
\text { mbi }\end{array}$ & W & $\mathrm{Sb}$ & Rt & Or & 0.38 & 10 & $\begin{array}{l}\text { Root is boiled in water and the resulting decoction is } \\
\text { drunk }\end{array}$ & $\begin{array}{l}\text { Diuretic/cleanse kidney } \\
\text { Gonorrhea, pain of waist, legs or joints }\end{array}$ & RPC007 \\
\hline & $\begin{array}{l}\text { Croton } \\
\text { dichogamus } \\
\text { Pax. }\end{array}$ & $\begin{array}{l}\text { Oloibor } \\
\text { benek }\end{array}$ & W & $\mathrm{Sb}$ & Rt & Or & 0.24 & 5 & $\begin{array}{l}\text { Roots' decoction is mixed with meat broth/stock and } \\
\text { drunk }\end{array}$ & $\begin{array}{l}\text { Pain of joints, back and waist, reliefs } \\
\text { tiredness, provides food (broth/stock) } \\
\text { taste }\end{array}$ & RPC073 \\
\hline & $\begin{array}{l}\text { Croton } \\
\text { macrostachyus } \\
\text { Del. }\end{array}$ & Oloiyapiyap & w & T & LBRt & Or & 0.38 & 14 & $\begin{array}{l}\text { Roots' decoction is mixed with honey, Aloe sp root } \\
\text { and decoction of other herbs and the formed mixture } \\
\text { ('opururua') is drunk or bark decoction is mixed with } \\
\text { meat broth/stock and drunk }\end{array}$ & $\begin{array}{l}\text { Induces diarrhea and treats intestinal } \\
\text { parasites (worms) }\end{array}$ & RPCO05 \\
\hline & & & & & & & & & Fresh leaves are cooked and eaten & Vegetable food, treats intestinal worms & \\
\hline
\end{tabular}


Table 2 Description on the habitat, habit, part used, route of administration, use value, relative frequency of citation, mode of preparation and human illness treated or role performed by flora used by MSPs in Monduli Districts, Arusha, 2021 (continued)

\begin{tabular}{|c|c|c|c|c|c|c|c|c|c|c|c|}
\hline Family & Scientific name & $\begin{array}{l}\text { Vernacular } \\
\text { name } \\
\text { (Maasai) }\end{array}$ & Habitat & Habit & PU & RA & UV & RFC & Preparation and application & $\begin{array}{l}\text { Illness or disease condition treated / role } \\
\text { performed }\end{array}$ & $\begin{array}{l}\text { Collection } \\
\text { No. }\end{array}$ \\
\hline \multirow[t]{7}{*}{ Euphorbiaceae } & $\begin{array}{l}\text { Croton } \\
\text { megalocarpus } \\
\text { Hutch }\end{array}$ & Ormarbait & w & T & Bk & Or & 0.86 & 19 & Fresh milk is infused with bark powder and drunk & $\begin{array}{l}\text { Induces diarrhea, treats 'OSUPETAl', intestinal } \\
\text { parasites (worms), pain of joints, back, waist } \\
\text { and clean or detoxify the body }\end{array}$ & RPC053 \\
\hline & Crotonsp. & $\begin{array}{l}\text { Enjanie- } \\
\text { emburkel }\end{array}$ & w & $\mathrm{Sb}$ & SBk & Or & 0.57 & 14 & $\begin{array}{l}\text { Meat broth /stock or cold water is infused with stem } \\
\text { powder and drunk }\end{array}$ & $\begin{array}{l}\text { Reliefs stomachache, facilitates food digestion, } \\
\text { increases appetite, cleanse kidney (diuretic), } \\
\text { increases body heat }\end{array}$ & RPC089 \\
\hline & & & & & & & & & $\begin{array}{l}\text { Milk tea / meat broth or stock / cold water is infused } \\
\text { with bark powder and drunk }\end{array}$ & $\begin{array}{l}\text { Boil/swelling, gonorrhea, 'ENARPOSESENI' } \\
\text { (hernia), worms, malaria and facilitates food } \\
\text { digestion, increases appetite, induces abortion }\end{array}$ & \\
\hline & Euphorbiasp & Emukutie & w & $\mathrm{H}$ & Rt & Or & 0.19 & 10 & $\begin{array}{l}\text { Fresh root is chewed and the resulting juice is } \\
\text { swallowed }\end{array}$ & $\begin{array}{l}\text { Cough, tonsillitis, restore lost voice due to } \\
\text { excessive singing }\end{array}$ & RPC085 \\
\hline & $\begin{array}{l}\text { Ricinus } \\
\text { communis L. }\end{array}$ & Oldule & w & $\mathrm{Sb}$ & FRt & Or & 0.29 & 14 & $\begin{array}{l}\text { Seeds are squeezed and the formed oil is mixed with } \\
\text { Senna didymobotrya leaves decoction and drunk }\end{array}$ & $\begin{array}{l}\text { Induces diarrhea and remove infected chest } \\
\text { mucus }\end{array}$ & RPC049 \\
\hline & & & & & & & & & $\begin{array}{l}\text { Roots' decoction is mixed with honey, Aloe sp roots } \\
\text { and decoction of other herbs and the formed } \\
\text { mixture ('opururua') is drunk }\end{array}$ & Diuretic/cleanse kidney and build the body & \\
\hline & $\begin{array}{l}\text { Tragia } \\
\text { ukambensis Pax } \\
\text { var.ukambensis }\end{array}$ & Engipwapwa & w & $\mathrm{H}$ & Rt & Or & 0.10 & 5 & $\begin{array}{l}\text { Roots' decoction is mixed with honey and decoction } \\
\text { of Hydnora abyssinica rhizomes and Asparagus } \\
\text { setaceus roots }\end{array}$ & Blood pressure and diabetes. & RPC080 \\
\hline \multirow[t]{2}{*}{ Fabaceae } & $\begin{array}{l}\text { Acacia nilotica } \\
\text { (L.) Wild ex } \\
\text { Delile }\end{array}$ & Orkiloriti & w & $T$ & FBRt & Or & 1.05 & 33 & $\begin{array}{l}\text { Decoction of dry fruits or bark is mixed with meat } \\
\text { broth/stock or tea is infused with bark powder and } \\
\text { drunk }\end{array}$ & $\begin{array}{l}\text { Pain of muscles and joints, gonorrhea, relief } \\
\text { tiredness, dissolves animal fats and facilitate } \\
\text { food digestion, provides viscosity and good } \\
\text { taste of meat broth/stock, builds the body, } \\
\text { cleanse kidney (diuretic), increases 'MORI'/ } \\
\text { 'EMBOSHONA' (confidence or angriness) }\end{array}$ & RPC063 \\
\hline & & & & & & & & & $\begin{array}{l}\text { Root is boiled in water and the formed decoction is } \\
\text { drunk or roots' decoction is mixed with meat } \\
\text { broth/stock and drunk }\end{array}$ & $\begin{array}{l}\text { Reliefs joints pain \& body weakness, induces } \\
\text { diarrhea \& muscles dislocation }\end{array}$ & \\
\hline
\end{tabular}


Table 2 Description on the habitat, habit, part used, route of administration, use value, relative frequency of citation, mode of preparation and human illness treated or role performed by flora used by MSPs in Monduli Districts, Arusha, 2021 (continued)

\begin{tabular}{|c|c|c|c|c|c|c|c|c|c|c|c|}
\hline Family & $\begin{array}{l}\text { Scientific } \\
\text { name }\end{array}$ & $\begin{array}{l}\text { Vernacular } \\
\text { name (Maasai) }\end{array}$ & Habitat & Habit & PU & RA & UV & RFC & Preparation and application & $\begin{array}{l}\text { Illness or disease condition treated / role } \\
\text { performed }\end{array}$ & $\begin{array}{l}\text { Collection } \\
\text { No. }\end{array}$ \\
\hline \multirow[t]{10}{*}{ Fabaceae } & $\begin{array}{l}\text { Albizia } \\
\text { anthelmintica } \\
\text { Brongn }\end{array}$ & Emukutan & W & $\mathrm{T}$ & BRt & Or & 1.48 & 52 & $\begin{array}{l}\text { Fresh milk is infused with bark powder and left for } \\
\text { about } 4 \text { days and drunk, or bark decoction is mixed } \\
\text { with meat broth/stock and drunk }\end{array}$ & $\begin{array}{l}\text { Intestinal parasites (worms), increases } \\
\text { body heat }\end{array}$ & RPC062 \\
\hline & & & & & & & & & $\begin{array}{l}\text { Roots' powder decoction is mixed with Embelia } \\
\text { schimperi decoction and lamb tallow (fats) then drunk } \\
\text { or }\end{array}$ & $\begin{array}{l}\text { Intestinal parasites (worms), antidote for a } \\
\text { swallowed poison, treats 'OSUPETAI', } \\
\text { fever, boil or swelling, and gonorrhea }\end{array}$ & \\
\hline & & & & & & & & & $\begin{array}{l}\text { Roots' decoction is mixed with fresh milk and meat } \\
\text { broth/stock or with milk/meat broth alone or with } \\
\text { cow blood and drunk }\end{array}$ & $\begin{array}{l}\text { Increases body heat, induces the bile juice } \\
\text { vomiting (treats-malaria), induces diarrhea }\end{array}$ & \\
\hline & $\begin{array}{l}\text { Albizia harveyi } \\
\text { E. Fourn. }\end{array}$ & Orperelong'o & w & T & Bk & Or & 0.10 & 5 & $\begin{array}{l}\text { Bark decoction is mixed with meat broth/stock and } \\
\text { drunk }\end{array}$ & $\begin{array}{l}\text { Provides a good taste of meat broth/stock } \\
\text { and build the body }\end{array}$ & RPC078 \\
\hline & $\begin{array}{l}\text { Dalbergia } \\
\text { melanoxylon } \\
\text { Guill. \& Perr. }\end{array}$ & Oltiasika & w & T & Rt & Or & 0.14 & 14 & $\begin{array}{l}\text { Roots' decoction is mixed with meat broth/stock or } \\
\text { decoction of its roots and that of Withania somnifera } \\
\text { roots are mixed with meat broth/stock then drunk }\end{array}$ & $\begin{array}{l}\text { Joins fast a broken bone and treats an } \\
\text { internal wound }\end{array}$ & RPC074 \\
\hline & $\begin{array}{l}\text { Lablab } \\
\text { purpureus (L.) }\end{array}$ & Ngwara & FM & $\mathrm{H}$ & Sd & Or & 0.19 & 10 & $\begin{array}{l}\text { Seeds are cooked in water then the formed soup is } \\
\text { drunk or eaten }\end{array}$ & Joins a broken bone and is a food source & RPC094 \\
\hline & $\begin{array}{l}\text { sweet subsp. } \\
\text { uncinatus } \\
\text { Verdc. }\end{array}$ & & & & & & & & $\begin{array}{l}\text { Seeds can be cooked with banana and infused with } \\
\text { Caesalpinia decapetala root then eaten as medicine }\end{array}$ & Medium for the herbal medicine & \\
\hline & $\begin{array}{l}\text { Lonchocarpus } \\
\text { eriocalyx } \\
\text { Harms }\end{array}$ & Embararwai & W & T & Lf & & 0.10 & 10 & Fresh leaves are crafted into a mat ('enaraa') & $\begin{array}{l}\text { Holds animal or meat in the slaughtering } \\
\text { process and prevents contamination }\end{array}$ & RPC061 \\
\hline & $\begin{array}{l}\text { Tamarindus } \\
\text { indica L. }\end{array}$ & $\begin{array}{l}\text { Orperelong'o } \\
\text { /Ormasamburai }\end{array}$ & W & T & $\mathrm{Ft}$ & Or & 0.19 & 19 & $\begin{array}{l}\text { Fruit is chewed and the soft part is swallowed, or } \\
\text { processed into a juice and drunk }\end{array}$ & Source of food & RPCO60 \\
\hline & $\begin{array}{l}\text { Vigna parkeri } \\
\text { Baker subsp. } \\
\text { acutifolia } \\
\text { Verdc }\end{array}$ & Orkalei & W-FM & $\mathrm{Cl}$ & $\mathrm{Tb}$ & Or & 0.10 & 5 & Tuber is chewed and the resulting juice is swallowed & Source of food and stop thirst & RPC087 \\
\hline
\end{tabular}


Table 2 Description on the habitat, habit, part used, route of administration, use value, relative frequency of citation, mode of preparation and human illness treated or role performed by flora used by MSPs in Monduli Districts, Arusha, 2021 (continued)

\begin{tabular}{|c|c|c|c|c|c|c|c|c|c|c|c|}
\hline Family & $\begin{array}{l}\text { Scientific } \\
\text { name }\end{array}$ & $\begin{array}{l}\text { Vernacular } \\
\text { name (Maasai) }\end{array}$ & Habitat & Habit & PU & RA & uV & RFC & Preparation and application & $\begin{array}{l}\text { Illness or disease condition treated / } \\
\text { role performed }\end{array}$ & $\begin{array}{l}\text { Collection } \\
\text { No. }\end{array}$ \\
\hline \multirow[t]{4}{*}{ Flacourtiaceae } & Dovyalis & Emaduai & W & T & FSRt & Or & 0.67 & 52 & Fruit is chewed and swallowed & Source of food & RPC017 \\
\hline & (A.Rich.) Warb. & & & & & & & & Stem is curved into a mortar ('engiuri') & Grinds food staffs or herbal medicines & \\
\hline & & & & & & & & & $\begin{array}{l}\text { Roots' decoction is mixed with meat broth/stock and } \\
\text { drunk }\end{array}$ & Appetizer in meat broth/stock & \\
\hline & $\begin{array}{l}\text { Oncoba } \\
\text { routledgei } \\
\text { Sprague }\end{array}$ & Emoroo & w & $\mathrm{Sb}$ & $\mathrm{Ft}$ & Or & 0.10 & 10 & Fruit is chewed and the soft part is swallowed & Source of food & RPC024 \\
\hline \multirow[t]{3}{*}{ Hydnoraceae } & $\begin{array}{l}\text { Hydnora } \\
\text { abyssinica A. }\end{array}$ & Erukunyi & W & Srp & $\mathrm{Ft}$ & Or & 0.24 & 19 & $\begin{array}{l}\text { Fresh fruit is chewed or warmed on fire like a potato and } \\
\text { eaten. }\end{array}$ & Food source & RPC101 \\
\hline & Braun & & & & Rz & & & & $\begin{array}{l}\text { Dry rhizome is grinded into powder and its decoction is } \\
\text { mixed with honey and roots' decoction of Tragia } \\
\text { ukambensis \& Asparagus setaceus then drunk }\end{array}$ & Blood pressure and diabetes & \\
\hline & & & & & & & & & $\begin{array}{l}\text { Fresh rhizome or its powder is boiled in water and the } \\
\text { formed decoction is drunk }\end{array}$ & Stomachache or diarrhea & \\
\hline \multirow[t]{6}{*}{ Lamiaceae } & Leucas sp & Enjaniengusero & W & H & LWp & Or & 0.10 & 5 & $\begin{array}{l}\text { Leaves or whole aerial part is boiled in water and the } \\
\text { formed decoction is drunk }\end{array}$ & Stomachache and pneumonia & RPC084 \\
\hline & $\begin{array}{l}\text { Ocimum } \\
\text { gratissimum }\end{array}$ & Ormanyinyikwai & w & $\mathrm{H}$ & LRt & Or & 0.48 & 19 & $\begin{array}{l}\text { Milk tea / tea is infused with leaves and drunk or fresh } \\
\text { leaves is chewed and the formed juice is swallowed }\end{array}$ & $\begin{array}{l}\text { Flue, releases stomach gas, provides } \\
\text { good taste/flavor }\end{array}$ & RPC027 \\
\hline & & & & & & & & & $\begin{array}{l}\text { Leaves decoction is mixed with decoction of Eucalyptus } \\
\text { saligna leaves and drunk }\end{array}$ & $\begin{array}{l}\text { Joints (finger \& knee) pain, cleanse } \\
\text { kidney (diuretic) }\end{array}$ & \\
\hline & & & & & & & & & $\begin{array}{l}\text { Roots decoction is mixed with meat broth/stock, or roots' } \\
\text { decoction is mixed with decoction of Solanum incanum } \\
\text { and Lippia kituiensis roots and drunk }\end{array}$ & Fever, joints pain & \\
\hline & $\begin{array}{l}\text { Tetradenia } \\
\text { riparia } \\
\text { (Hochst.) }\end{array}$ & Ormakingi & W-HG & H & LWp & $\begin{array}{l}\text { Or } \\
\text { Oc }\end{array}$ & 0.24 & 14 & $\begin{array}{l}\text { Leaves are squeezed and the resulting juice swallowed or } \\
\text { put into a cavity of infected teeth or an infected eye }\end{array}$ & $\begin{array}{l}\text { Stomachache, tooth pain and eye } \\
\text { infection }\end{array}$ & RPCO46 \\
\hline & Codd. & & & & & $\begin{array}{l}\text { De } \\
\mathrm{Na}\end{array}$ & & & $\begin{array}{l}\text { Leaves or whole aerial part hot decoction in mixture with } \\
\text { artemisia annua leaves decoction steamed on the body }\end{array}$ & Treats dry cough and flue & \\
\hline
\end{tabular}


Table 2 Description on the habitat, habit, part used, route of administration, use value, relative frequency of citation, mode of preparation and human illness treated or role performed by flora used by MSPs in Monduli Districts, Arusha, 2021 (continued)

\begin{tabular}{|c|c|c|c|c|c|c|c|c|c|c|c|}
\hline Family & $\begin{array}{l}\text { Scientific } \\
\text { name }\end{array}$ & $\begin{array}{l}\text { Vernacular } \\
\text { name } \\
\text { (Maasai) }\end{array}$ & Habitat & Habit & PU & RA & UV & RFC & Preparation and application & $\begin{array}{l}\text { Illness or disease condition treated / } \\
\text { role performed }\end{array}$ & $\begin{array}{l}\text { Collection } \\
\text { No. }\end{array}$ \\
\hline \multirow[t]{2}{*}{ Lauraceae } & $\begin{array}{l}\text { Persea } \\
\text { americana }\end{array}$ & Orparachichi & HG & $T$ & LFt & Or & 0.29 & 14 & $\begin{array}{l}\text { Fresh leaves' decoction is mixed with decoction of } Z \text {. } \\
\text { deremense root and Psidium guajava leaves then drunk }\end{array}$ & Fever/malaria & RPC056 \\
\hline & & & & & & & & & Fruit is chewed and swallowed & Source of food & \\
\hline \multirow[t]{5}{*}{ Malvaceae } & $\begin{array}{l}\text { Abutilon } \\
\text { longicuspe A. }\end{array}$ & Oldadai & w & $\mathrm{Sb}$ & SBk & & 0.19 & 10 & $\begin{array}{l}\text { Stem is curved into a sharp end stick ('orjibet'), pierced } \\
\text { into meat pieces and erect beside fire }\end{array}$ & Holds meat in the roasting process & RPC020 \\
\hline & & & & & & & & & Bark is streamed into a rope & Tie food staffs/herbs or other materials & \\
\hline & $\begin{array}{l}\text { Thespesia } \\
\text { garckeana } \mathrm{F} .\end{array}$ & Emotoo & W & $\mathrm{T}$ & LFSt & Or & 0.24 & 14 & Fresh leaves are crafted into a mat ('enaraa') & $\begin{array}{l}\text { Hold animal/meat and prevent } \\
\text { contamination in a slaughtering process }\end{array}$ & RPC095 \\
\hline & & & & & & & & & Fruits is chewed and soft part swallowed & Source of food & \\
\hline & & & & & & & & & $\begin{array}{l}\text { Stem is curved into a sharp end stick ('orjibet'), pierced } \\
\text { through meat pieces and erect beside fire }\end{array}$ & Holds meat in the roasting process & \\
\hline \multirow[t]{2}{*}{ Meliaceae } & $\begin{array}{l}\text { Ekebergia } \\
\text { capensis } \\
\text { Sparrm }\end{array}$ & Ormukuna & W & T & St & & 0.14 & 14 & Stem is curved into a mortar ('engiuri') & Grinds food staffs or herbal medicines & RPC022 \\
\hline & $\begin{array}{l}\text { Lepidotrichilia } \\
\text { volkensii } \\
\text { (Gürke) J.- } \\
\text { F.Leroy }\end{array}$ & Engilelekuru & w & T & Rt & Or & 0.33 & 19 & $\begin{array}{l}\text { Roots' decoction is mixed with meat broth/stock, or it is } \\
\text { mixed with fresh goat feces juice and drunk } \\
\text { Roots' decoction is drunk along with fresh goat skin } \\
\text { wrapping on a neck }\end{array}$ & $\begin{array}{l}\text { Diuretic/cleanse kidney, treats joints } \\
\text { pain, boil/swelling on breast, legs, or } \\
\text { other parts, excess causes vomiting } \\
\text { Tonsillitis }\end{array}$ & RPC023 \\
\hline Melianthaceae & $\begin{array}{l}\text { Bersama } \\
\text { abyssinica } \\
\text { Fresen }\end{array}$ & Eng'arangupe & W & $T$ & Rt & Or & 0.10 & 10 & $\begin{array}{l}\text { Roots' decoction is mixed with meat broth/stock and } \\
\text { drunk }\end{array}$ & Diuretic/cleanse kidney & RPCO03 \\
\hline \multirow[t]{2}{*}{ Mimosaceae } & Acacia sp & Orimbai & W & T & Bk & Or & 0.19 & 10 & Bark is boiled in water and the resulting decoction is drunk & Stomachache and 'OSUPETAI' & RPC041 \\
\hline & Acaciasp. & Osiyamalei & w & T & Bk & Or & 0.14 & 5 & Bark decoction is mixed with meat broth/stock and drunk & $\begin{array}{l}\text { Treats joints' pain and inflammation, } \\
\text { increases 'MORI'/'EMBOSHONA' }\end{array}$ & RPC068 \\
\hline Moraceae & $\begin{array}{l}\text { Ficus } \\
\text { sycomorus L. }\end{array}$ & Orng'aboli & w & T & $\mathrm{Ft}$ & Or & 0.05 & 5 & Fruit is chewed and swallowed & Source of food & RPCO90 \\
\hline
\end{tabular}


Table 2 Description on the habitat, habit, part used, route of administration, use value, relative frequency of citation, mode of preparation and human illness treated or role performed by flora used by MSPs in Monduli Districts, Arusha, 2021 (continued)

\begin{tabular}{|c|c|c|c|c|c|c|c|c|c|c|c|}
\hline Family & Scientific name & $\begin{array}{l}\text { Vernacular } \\
\text { name } \\
\text { (Maasai) }\end{array}$ & Habitat & Habit & PU & RA & UV & RFC & Preparation and application & $\begin{array}{l}\text { Illness or disease condition treated / role } \\
\text { performed }\end{array}$ & $\begin{array}{l}\text { Collection } \\
\text { No. }\end{array}$ \\
\hline \multirow[t]{4}{*}{ Moraceae } & $\begin{array}{l}\text { Ficus thonningii } \\
\text { Blume }\end{array}$ & Oreteti & W & $\mathrm{T}$ & BRt & Or & 1.10 & 52 & $\begin{array}{l}\text { Bark/root is boiled into water and the formed } \\
\text { decoction is drunk or bark/root powder is swallowed }\end{array}$ & Stop diarrhea & RPC028 \\
\hline & & & & & & & & & $\begin{array}{l}\text { Fresh roots' bark is peeled and the inner part is } \\
\text { chewed like gum }\end{array}$ & Stop thirst & \\
\hline & & & & & & & & & Roots' woody is crafted into a brush ('esosian') & $\begin{array}{l}\text { Spreads and cleans herbal ashes/smoke in a } \\
\text { calabash for food preservation }\end{array}$ & \\
\hline & & & & & & & & & Whole aerial part is surrounded by people & Ritual purpose & \\
\hline \multirow[t]{8}{*}{ Myrsinaceae } & $\begin{array}{l}\text { Embelia } \\
\text { schimperi } \\
\text { Vatke }\end{array}$ & $\begin{array}{l}\text { Olchani } \\
\text { onyokie }\end{array}$ & w & $\mathrm{Sb}$ & LBRt & Or & 1.43 & 48 & $\begin{array}{l}\text { Leaves are chewed and swallowed } \\
\text { Hot/cold water is infused with bark powder and } \\
\text { drunk }\end{array}$ & $\begin{array}{l}\text { Source of food } \\
\text { Pain of joints, back, muscles and ribs } \\
\text { Also treats Anaplasmosis in cattle }\end{array}$ & RPC037 \\
\hline & & & & & & & & & $\begin{array}{l}\text { Bark powder decoction is mixed with 'iloodwa'/ } \\
\text { 'ngesi' powder decoction and fresh milk or lamb } \\
\text { tallow (fats) then drunk. }\end{array}$ & 'OSUPETAI' or 'OLGILA', boil, gonorrhea & \\
\hline & & & & & & & & & Bark is warmed and chewed along with honey & $\begin{array}{l}\text { Flue, cough, fever, stomachache and throats' } \\
\text { wounds }\end{array}$ & \\
\hline & & & & & & & & & Bark/root powder decoction is mixed with Albizia & Induces diarrhea, treats joint (finger/knee) & \\
\hline & & & & & & & & & anthelmintica roots' decoction and lamb tallow (fats) & inflammation, boil 'OSUPETAl', gonorrhea. & \\
\hline & & & & & & & & & or bark powder decoction is mixed with tallow (fats) & $\begin{array}{l}\text { Note: Embelia schimperi induces excess } \\
\text { menstrual flow and abortion }\end{array}$ & \\
\hline & $\begin{array}{l}\text { Rapanea } \\
\text { melanophloeos } \\
\text { (L.) Mez. }\end{array}$ & $\begin{array}{l}\text { lloodwa / } \\
\text { Engodwai }\end{array}$ & W-HG & $\mathrm{T}$ & $\mathrm{Ft}$ & Or & 1.33 & 29 & $\begin{array}{l}\text { Dry fruits are grinded into powder and swallowed } \\
\text { along with Coca-Cola soda / salt water solution or } \\
\text { mixed with a hot lamb tallow (fat) and swallowed. }\end{array}$ & $\begin{array}{l}\text { Diuretic/cleanse kidney, treats gonorrhea, } \\
\text { internal wound, intestinal parasite and } \\
\text { 'OSUPETAl' }\end{array}$ & RPCO99 \\
\hline & & & & & & & & & $\begin{array}{l}\text { Fruits' powder decoction is mixed with Embelia } \\
\text { schimperi bark powder decoction \& fresh milk or } \\
\text { lamb fats and drunk. }\end{array}$ & $\begin{array}{l}\text { Induces diarrhea, treats joint pain, Intestinal } \\
\text { parasites (worms) and 'OSUPETAl' }\end{array}$ & \\
\hline \multirow[t]{3}{*}{ Myrtaceae } & $\begin{array}{l}\text { Eucalyptus } \\
\text { saligna Smith }\end{array}$ & Orkelebu & HG-FM & $\mathrm{T}$ & LSt & Or & 0.19 & 10 & $\begin{array}{l}\text { Leaves are boiled with Ocimum gratissimum leaves } \\
\text { in water and the formed decoction is drunk }\end{array}$ & $\begin{array}{l}\text { Diuretic/cleanse kidney, treats joints (finger \& } \\
\text { knee) pain }\end{array}$ & RPC044 \\
\hline & & & & & & & & & $\begin{array}{l}\text { Stem is curved into a sharp end stick ('orjibet'), } \\
\text { pierced through meat pieces and erect beside fire }\end{array}$ & Holds meat in the roasting process & \\
\hline & & & & & & & & & Stem is crafted into a pestle ('emushi') & Grinds food staffs or herbal medicines & \\
\hline
\end{tabular}


Table 2 Description on the habitat, habit, part used, route of administration, use value, relative frequency of citation, mode of preparation and human illness treated or role performed by flora used by MSPs in Monduli Districts, Arusha, 2021 (continued)

\begin{tabular}{|c|c|c|c|c|c|c|c|c|c|c|c|}
\hline Family & Scientific name & $\begin{array}{l}\text { Vernacular } \\
\text { name } \\
\text { (Maasai) }\end{array}$ & Habitat & Habit & PU & RA & uv & RFC & Preparation and application & $\begin{array}{l}\text { Illness or disease condition treated / role } \\
\text { performed }\end{array}$ & $\begin{array}{l}\text { Collection } \\
\text { No. }\end{array}$ \\
\hline Myrtaceae & $\begin{array}{l}\text { Psidium } \\
\text { guajava L. }\end{array}$ & Ormaperai & HG & T & LFt & Or & 0.29 & 14 & $\begin{array}{l}\text { Leaves are boiled with Zanthoxylum deremense or } \\
\text { chalybeum roots and Persea americana leaves in } \\
\text { water and the formed decoction is drunk }\end{array}$ & Fever/malaria & RPC057 \\
\hline Nyctaginaceae & $\begin{array}{l}\text { Commicarpus } \\
\text { plumbagineus } \\
\text { (Cav.) standl }\end{array}$ & Orng'eriandus & w & $\mathrm{H}-\mathrm{Cl}$ & Rt & Or & 0.76 & 14 & $\begin{array}{l}\text { Fruit is chewed and swallowed } \\
\text { Root is boiled in water and the formed decoction is } \\
\text { drunk, or mixed with meat broth/stock or mixed } \\
\text { with fresh milk then drunk }\end{array}$ & $\begin{array}{l}\text { Source of food } \\
\text { Diuretic/cleanse kidney, treats inflammation } \\
\text { of a joint (knee/ankle), gonorrhea, } \\
\text { 'OSUPETAl', stomachache, pain of joints (knee } \\
\& \text { ankle), back, waist and bones }\end{array}$ & RPC088 \\
\hline \multirow[t]{3}{*}{ Olacaceae } & $\begin{array}{l}\text { Ximenia caffra } \\
\text { Sond }\end{array}$ & $\begin{array}{l}\text { Eng'gamai / } \\
\text { llama }\end{array}$ & w & $\mathrm{Sb}$ & FSBRt & Or & 1.43 & 52 & $\begin{array}{l}\text { Fruit is chewed and soft part is swallowed } \\
\text { Stem/bark/root is boiled in water and the formed } \\
\text { decoction is drunk or mixed with meat broth/stock } \\
\text { then drunk or roots' decoction is mixed with fresh } \\
\text { milk and tallow/clarified butter then drunk }\end{array}$ & $\begin{array}{l}\text { Source of food for human/cow/goat } \\
\text { Dissolves animal fats, provides color, taste, } \\
\text { odor \& viscosity to the meat broth/stock, and } \\
\text { add blood (red in color) } \\
\text { Diuretic/cleanse kidney } \\
\text { Joint pain, stomach ulcers, clean uterus, } \\
\text { reliefs uterus pain, stops excess menstrual } \\
\text { flow or bleeding and abortion in young } \\
\text { pregnancy, relaxes the body }\end{array}$ & RPC069 \\
\hline & $\begin{array}{l}\text { Olea europaea } \\
\text { subsp. africana } \\
\text { (Mill.) } \\
\text { P.S.Green }\end{array}$ & Oloirien & w & $T$ & St & $\begin{array}{l}\mathrm{Na} / \\
\mathrm{Or}\end{array}$ & 1.95 & 100 & $\begin{array}{l}\text { Stem is chopped into piece (s) which burn into a } \\
\text { smoke and ash then spread by brush ('esosian') } \\
\text { into the storage container (calabash) } \\
\text { Stem smoke is sniffed through nostrils }\end{array}$ & $\begin{array}{l}\text { Preserve, provide good odor, taste to the } \\
\text { liquid foods: milk, 'oloshoro', 'engitalolo', } \\
\text { 'euji' and 'emberere' } \\
\text { headache }\end{array}$ & RPC035 \\
\hline & & & & & & & & & $\begin{array}{l}\text { Curved sharp end stick ('orjibet') is pierced though } \\
\text { meat pieces and set beside fire }\end{array}$ & Holds meat in the roasting process & \\
\hline Papaveraceae & $\begin{array}{l}\text { Argemone } \\
\text { mexicana } \mathrm{L}\end{array}$ & Olemokolo & w & H & St & De & 0.05 & 5 & $\begin{array}{l}\text { Fresh stem is cut and the juice that oozes out is } \\
\text { applied on the wounded skin }\end{array}$ & Treat wounds & RPC077 \\
\hline \multirow[t]{2}{*}{ Piperaceae } & $\begin{array}{l}\text { Piper capense } \\
\text { L. f. }\end{array}$ & Olerubat & w & $T$ & Rt & Or & 0.48 & 24 & $\begin{array}{l}\text { Roots' decoction is mixed with meat broth/stock } \\
\text { and drunk }\end{array}$ & $\begin{array}{l}\text { Provides good taste and odor to the meat } \\
\text { broth/stock }\end{array}$ & RPC050 \\
\hline & & & & & & & & & & $\begin{array}{l}\text { Diuretic/cleanse kidney and blood, treats pain } \\
\text { of joints, boil/swelling and stomachache }\end{array}$ & \\
\hline
\end{tabular}


Table 2 Description on the habitat, habit, part used, route of administration, use value, relative frequency of citation, mode of preparation and human illness treated or role performed by flora used by MSPs in Monduli Districts, Arusha, 2021 (continued)

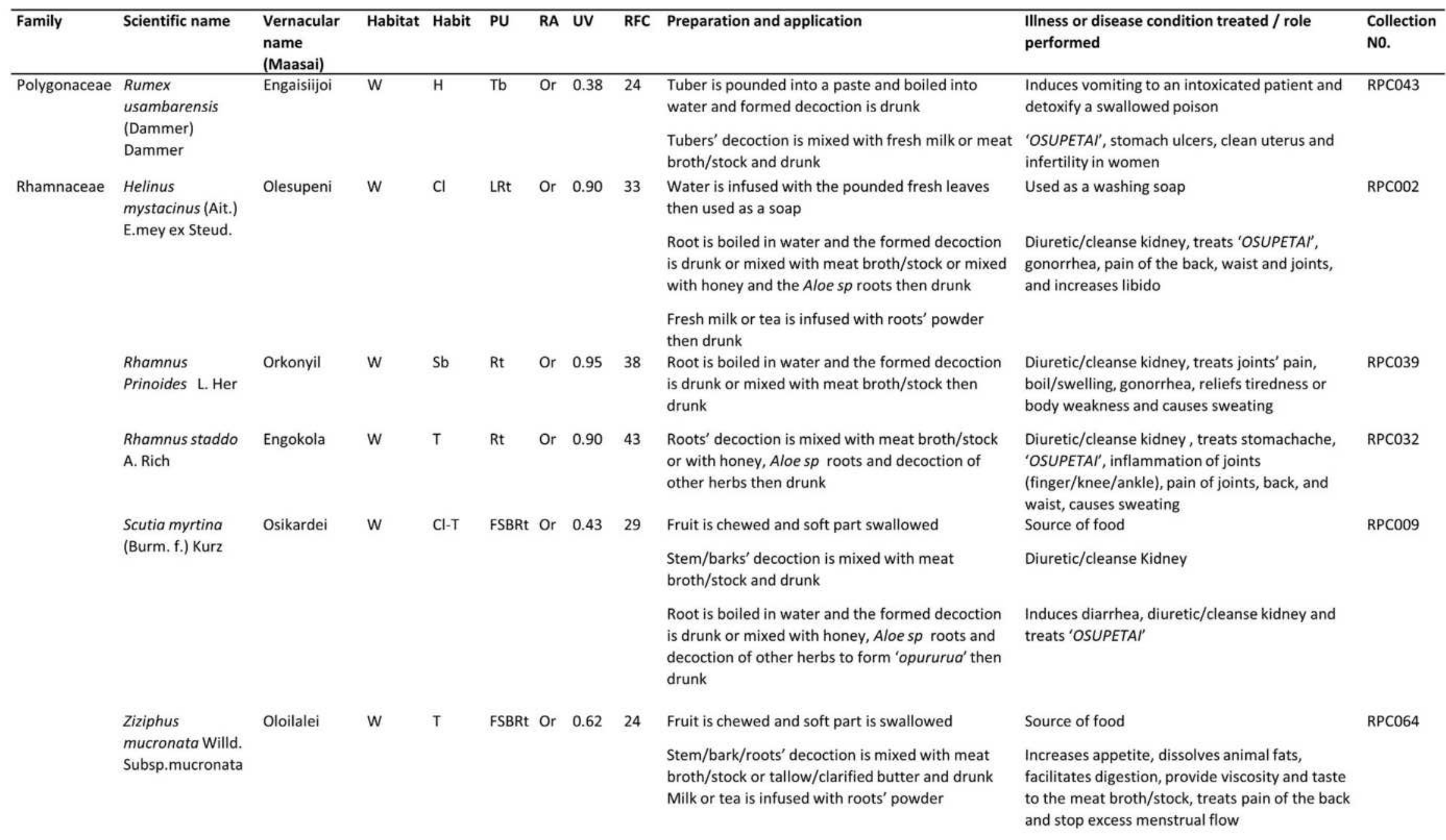


Table 2 Description on the habitat, habit, part used, route of administration, use value, relative frequency of citation, mode of preparation and human illness treated or role performed by flora used by MSPs in Monduli Districts, Arusha, 2021 (continued)

\begin{tabular}{|c|c|c|c|c|c|c|c|c|c|c|c|}
\hline Family & $\begin{array}{l}\text { Scientific } \\
\text { name }\end{array}$ & $\begin{array}{l}\text { Vernacular } \\
\text { name } \\
\text { (Maasai) }\end{array}$ & Habitat & Habit & PU & RA & UV & RFC & Preparation and application & $\begin{array}{l}\text { Illness or disease condition treated / role } \\
\text { performed }\end{array}$ & $\begin{array}{l}\text { Collection } \\
\text { No. }\end{array}$ \\
\hline Rubiaceae & $\begin{array}{l}\text { Vangueria } \\
\text { infausta Burch }\end{array}$ & $\begin{array}{l}\text { Emardanyi / } \\
\text { egumi }\end{array}$ & W & $T$ & $\mathrm{Ft}$ & Or & 0.81 & 81 & Fruit is chewed and soft part is swallowed & Source of food & RPCO30 \\
\hline \multirow[t]{10}{*}{ Rutaceae } & $\begin{array}{l}\text { Clausena } \\
\text { anisata } \\
\text { (Willd.) Hook. } \\
\text { F. Ex Benth }\end{array}$ & Ematasia & w & $\mathrm{Sb}$ & FSt & Or & 0.81 & 48 & $\begin{array}{l}\text { Fruit is chewed and soft part is swallowed } \\
\text { Stem is crafted into a tooth brush or curved into a } \\
\text { sharp end stick ('orjibet'), pierced into meat pieces } \\
\text { and set beside fire }\end{array}$ & $\begin{array}{l}\text { Source of food } \\
\text { Cleans teeth or holds meat in the roasting } \\
\text { process respectively }\end{array}$ & RPC034 \\
\hline & $\begin{array}{l}\text { Toddalia } \\
\text { asiatica (L.) }\end{array}$ & Olaiseremai & W & T-Sb & LFRt & Or & 0.19 & 19 & $\begin{array}{l}\text { Leaves are chewed and the formed juice is } \\
\text { swallowed }\end{array}$ & Stops milk in a lactating mother & RPC012 \\
\hline & & & & & & & & & $\begin{array}{l}\text { Roots' decoction is mixed with meat broth/stock } \\
\text { and drunk }\end{array}$ & Diuretic/cleanse kidney & \\
\hline & $\begin{array}{l}\text { Vepris } \\
\text { simplicifolia }\end{array}$ & Olgilai & W & T & SRt & Or & 0.86 & 38 & Stem is curved into an axe handle / a canning stick & $\begin{array}{l}\text { Holds axes for cutting materials or used to } \\
\text { provide punishment respectively }\end{array}$ & PRC011 \\
\hline & & & & & & & & & $\begin{array}{l}\text { Roots' decoction is mixed with meat broth/stock, } \\
\text { or mixed with honey/sugar and decoction of other } \\
\text { herbs to form 'opururua' / alcohol then drunk }\end{array}$ & $\begin{array}{l}\text { Diuretic/cleanse kidney (white urine), treats } \\
\text { fever, gonorrhea, intestinal parasite (worms), } \\
\text { 'OSUPETAl' }\end{array}$ & \\
\hline & $\begin{array}{l}\text { Zanthoxylum } \\
\text { deremense } \\
\text { (Engl.) }\end{array}$ & Oloisuki & w & T & FSBRt & $\begin{array}{l}\mathrm{Na} / \\
\mathrm{Or}\end{array}$ & 0.95 & 33 & $\begin{array}{l}\text { Milk tea/porridge / water/ meat broth or stock is } \\
\text { infused with powder of fruit / stem / bark / root } \\
\text { then drunk }\end{array}$ & $\begin{array}{l}\text { Cough, flue, fever/ malaria, pneumonia, } \\
\text { boil/swelling and 'OSUPETAl' }\end{array}$ & RPC054 \\
\hline & Kokwaro & & & & & & & & $\begin{array}{l}\text { Stem/bark/root is boiled in water and the formed } \\
\text { decoction is drunk or mixed with meat broth/stock } \\
\text { then drunk }\end{array}$ & & \\
\hline & & & & & & & & & $\begin{array}{l}\text { Roots' decoction is mixed with that of Persea } \\
\text { americana leaves and Psidium guajava leaves then } \\
\text { drunk }\end{array}$ & & \\
\hline & & & & & & & & & $\begin{array}{l}\text { Root is burn on fire and the smoke is sniffed } \\
\text { through nostrils }\end{array}$ & Headache & \\
\hline & $\begin{array}{l}\text { Zanthoxylum } \\
\text { chalybeum } \\
\text { Engl. }\end{array}$ & Oloisuki & w & T & FSBRt & $\begin{array}{l}\mathrm{Na} / \\
\text { Or }\end{array}$ & 0.95 & 33 & Same as Zanthoxylum deremense & Same as Zanthoxylum deremense & RPC100 \\
\hline
\end{tabular}


Table 2 Description on the habitat, habit, part used, route of administration, use value, relative frequency of citation, mode of preparation and human illness treated or role performed by flora used by MSPs in Monduli Districts, Arusha, 2021 (continued)

\begin{tabular}{|c|c|c|c|c|c|c|c|c|c|c|c|}
\hline Family & $\begin{array}{l}\text { Scientific } \\
\text { name }\end{array}$ & $\begin{array}{l}\text { Vernacular } \\
\text { name } \\
\text { (Maasai) }\end{array}$ & Habitat & Habit & PU & RA & UV & RFC & Preparation and application & $\begin{array}{l}\text { Illness or disease condition treated / role } \\
\text { performed }\end{array}$ & $\begin{array}{l}\text { Collection } \\
\text { No. }\end{array}$ \\
\hline \multirow[t]{3}{*}{ Sapindaceae } & $\begin{array}{l}\text { Deinbollia } \\
\text { borbonica } \\
\text { Scheff }\end{array}$ & $\begin{array}{l}\text { Oloibor } \\
\text { kulalet }\end{array}$ & W & $T$ & $\mathrm{Ft}$ & Or & 0.24 & 24 & Fruit is chewed and soft part is swallowed & Source of food & RPC013 \\
\hline & $\begin{array}{l}\text { Pappea } \\
\text { capensis Eckl. } \\
\text { \& Zeyh. }\end{array}$ & Endimigomi & W & T & SBRt & Or & 0.81 & 38 & $\begin{array}{l}\text { Stem decoction is mixed with meat broth/stock } \\
\text { or tallow/clarified butter then drunk or stem } \\
\text { decoction is drunk along with male cow blood }\end{array}$ & $\begin{array}{l}\text { Stomachache, increases libido, strength and } \\
\text { energy, clean veins and bones }\end{array}$ & RPC038 \\
\hline & & & & & & & & & $\begin{array}{l}\text { Tea or meat broth/ stock is infused with bark } \\
\text { powder or roots' decoction is mixed with meat } \\
\text { broth/stock then drunk }\end{array}$ & $\begin{array}{l}\text { Increases body heat, refresh and build the } \\
\text { body, treats pain of joints (knee \& waist, } \\
\text { Gonorrhea, fever and increases libido }\end{array}$ & \\
\hline Simaroubaceae & $\begin{array}{l}\text { Harrisonia } \\
\text { abyssinica Oliv. }\end{array}$ & Endundulu & w & $\mathrm{Sb}$ & Rt & Or & 1.14 & 38 & $\begin{array}{l}\text { Roots' decoction is mixed with meat broth/stock } \\
\text { or tea is infuse with roots' powder and drunk }\end{array}$ & $\begin{array}{l}\text { Pain of back, bones, muscles, joints, and waist } \\
\text { gonorrhea, syphilis, 'OSUPETAI', swelling on a } \\
\text { prostate, painless swelling (when pressed not } \\
\text { restore easily) on ankles/finger joints, } \\
\text { increases 'MORI'/ 'EMBOSHONA' }\end{array}$ & RPC072 \\
\hline \multirow[t]{5}{*}{ Solanaceae } & $\begin{array}{l}\text { Datura } \\
\text { stramonium L }\end{array}$ & $\begin{array}{l}\text { Oldule/ } \\
\text { Ormunanaa }\end{array}$ & w & $\mathrm{H}$ & Sd & Or & 0.05 & 5 & $\begin{array}{l}\text { Seeds are grinded into powder, mixed with fats or } \\
\text { margarine (Kasuku/Kimbo/Cow boy), roasted in a } \\
\text { pot connected with a funnel then the smoke is } \\
\text { directed to the infected teeth }\end{array}$ & $\begin{array}{l}\text { Pain of bored or infected teeth (with red } \\
\text { headed worms) }\end{array}$ & RPC079 \\
\hline & $\begin{array}{l}\text { Physalis } \\
\text { peruviana L. }\end{array}$ & Tamtam & HG & H & LFt & Or & 0.43 & 14 & $\begin{array}{l}\text { Leaves are chewed and the formed juice is } \\
\text { swallowed }\end{array}$ & Stomachache, releases stomach gas & RPC055 \\
\hline & & & & & & & & & Fruit is chewed and swallowed & Source of food & \\
\hline & $\begin{array}{l}\text { Solanum } \\
\text { aculeastrum } \\
\text { Dunal }\end{array}$ & Olturunga & W & $\mathrm{Sb}$ & Rt & Or & 0.38 & 10 & $\begin{array}{l}\text { Roots decoction is mixed with meat broth/stock } \\
\text { or roots' decoction is mixed with decoction of } \\
\text { Chenopodium schraderianum leaves then drunk }\end{array}$ & $\begin{array}{l}\text { Diuretic/ cleanse kidney treats boil/swelling, } \\
\text { joint pains, and reliefs tiredness }\end{array}$ & RPC025 \\
\hline & $\begin{array}{l}\text { Solanum } \\
\text { aethiopicum }\end{array}$ & Endemelwa & w & $\mathrm{H}$ & Rt & Or & 0.38 & 10 & $\begin{array}{l}\text { Roots' decoction is mixed with meat broth/stock } \\
\text { and drunk in soup }\end{array}$ & $\begin{array}{l}\text { Diuretic/cleanse kidney, treats 'OSUPETAI', } \\
\text { boil/swelling and reliefs tiredness }\end{array}$ & RPC021 \\
\hline
\end{tabular}


Table 2 Description on the habitat, habit, part used, route of administration, use value, relative frequency of citation, mode of preparation and human illness treated or role performed by flora used by MSPs in Monduli Districts, Arusha, 2021 (continued)

\begin{tabular}{|c|c|c|c|c|c|c|c|c|c|c|c|}
\hline Family & $\begin{array}{l}\text { Scientific } \\
\text { name }\end{array}$ & $\begin{array}{l}\text { Vernacular } \\
\text { name } \\
\text { (Maasai) }\end{array}$ & Habitat & Habit & PU & RA & UV & RFC & Preparation and application & $\begin{array}{l}\text { Illness or disease condition treated / role } \\
\text { performed }\end{array}$ & $\begin{array}{l}\text { Collection } \\
\text { No. }\end{array}$ \\
\hline \multirow[t]{4}{*}{ Solanaceae } & $\begin{array}{l}\text { Solanum } \\
\text { incanum } \mathrm{L} .\end{array}$ & Endulelei & w & $\mathrm{H}$ & FRt & Or & 0.57 & 10 & $\begin{array}{l}\text { Fruit is squeezed and the resulting juice is mixed } \\
\text { with soda ash dissolved in water then mixed with a } \\
\text { clotted blood }\end{array}$ & Dissolves clotted blood & RPC016 \\
\hline & & & & & & & & & $\begin{array}{l}\text { Root is boiled in water and the formed decoction is } \\
\text { drunk or mixed with meat broth/ stock and drunk or } \\
\text { root is chewed and swallowed }\end{array}$ & Hernia, flue, fever, pneumonia and joints' pain & \\
\hline & $\begin{array}{l}\text { Withania } \\
\text { somnifera (L.) }\end{array}$ & Olesayet & w & $H$ & LSRt & $\begin{array}{l}\text { De/ } \\
\text { Or }\end{array}$ & 2.67 & 48 & $\begin{array}{l}\text { Leaves are squeezed into a juice or the leaves/stem } \\
\text { / root is burn into ashes and put on a wound }\end{array}$ & Treats wound & RPC014 \\
\hline & Dunal & & & & & & & & $\begin{array}{l}\text { Roots' decoction is mixed with meat broth/stock or } \\
\text { with fresh milk and honey, or milk tea is infused } \\
\text { with roots' powder then drunk }\end{array}$ & $\begin{array}{l}\text { Diuretic/ cleanse kidney, treats pain of joints, } \\
\text { back and waist, joints' swelling, boil, ulcers } \\
\text { gonorrhea and 'OSUPETAl' }\end{array}$ & \\
\hline \multirow[t]{2}{*}{ Sterculiaceae } & $\begin{array}{l}\text { Dombeya kirkii } \\
\text { Mast }\end{array}$ & Orporokwai & w & $\mathrm{T}$ & SBRt & Or & 0.38 & 19 & $\begin{array}{l}\text { Stem is curved into a sharp end stick, pierced into } \\
\text { meat pieces and erect beside fire }\end{array}$ & Hold meat in the roasting process & RPC066 \\
\hline & & & & & & & & & $\begin{array}{l}\text { Bark or roots' decoction is mixed with meat } \\
\text { broth/stock and drunk }\end{array}$ & $\begin{array}{l}\text { Provides taste and viscosity to the meat } \\
\text { broth/stock, dissolves and stop deposit of fats } \\
\text { in a stomach, dissolves animal fats and stop its } \\
\text { deposit in a stomach, diuretic/cleanse kidney, } \\
\text { treats pain of urinary tract }\end{array}$ & \\
\hline \multirow[t]{4}{*}{ Tiliaceae } & $\begin{array}{l}\text { Grewia bicolor } \\
\text { Juss. }\end{array}$ & Ositeti & w & $\mathrm{Sb}$ & LFSRt & $\begin{array}{l}\mathrm{Na} / \\
\text { Or }\end{array}$ & 1.62 & 57 & $\begin{array}{l}\text { Fresh leaves are crafted or made into a mat or used } \\
\text { to squeeze coagulated blood }\end{array}$ & $\begin{array}{l}\text { Hold animal/meat and prevent its } \\
\text { contamination in the slaughtering process or } \\
\text { dissolves coagulated blood }\end{array}$ & RPC071 \\
\hline & & & & & & & & & Fruit is chewed and soft part swallowed & Source of food & \\
\hline & & & & & & & & & $\begin{array}{l}\text { Stem is crafted in a stirrer handle or sharp end sticks } \\
\text { which is pierced through meat and erect beside fire }\end{array}$ & $\begin{array}{l}\text { Stirring liquid food or hold meat in the } \\
\text { roasting process }\end{array}$ & \\
\hline & & & & & & & & & $\begin{array}{l}\text { Stem is burn into smoke and ashes spread into a } \\
\text { calabash burning stick or roots' decoction is mixed } \\
\text { with meat broth/stock }\end{array}$ & $\begin{array}{l}\text { Provides, taste, odor/flavor and preserves } \\
\text { food }\end{array}$ & \\
\hline
\end{tabular}


Table 2 Description on the habitat, habit, part used, route of administration, use value, relative frequency of citation, mode of preparation and human illness treated or role performed by flora used by MSPs in Monduli Districts, Arusha, 2021 (continued)

\begin{tabular}{|c|c|c|c|c|c|c|c|c|c|c|c|}
\hline Family & Scientific name & $\begin{array}{l}\text { Vernacular } \\
\text { name } \\
\text { (Maasai) }\end{array}$ & Habitat & Habit & PU & RA & UV & RFC & Preparation and application & $\begin{array}{l}\text { Illness or disease condition treated / role } \\
\text { performed }\end{array}$ & $\begin{array}{l}\text { Collection } \\
\text { No. }\end{array}$ \\
\hline Tiliaceae & $\begin{array}{l}\text { Grewia villosa } \\
\text { Willd }\end{array}$ & Irmangula & W & $\mathrm{Sb}$ & FRt & Or & 0.76 & 38 & $\begin{array}{l}\text { Fruit is chewed and soft part is swallowed, or is mixed } \\
\text { with water to form a juice then is drunk } \\
\text { Roots' decoction is mixed with fresh milk \& } \\
\text { tallow/clarified butter }\end{array}$ & $\begin{array}{l}\text { Source of food, excess fruits' seed makes } \\
\text { stool stiff and obstructs defecation } \\
\text { Clean uterus, reliefs uterus pain and stop } \\
\text { bleeding/abortion in young pregnancy }\end{array}$ & RPC081 \\
\hline Urticaceae & $\begin{array}{l}\text { Urtica massaica } \\
\text { Mildbr. }\end{array}$ & Olmatejo & w & H & LRt & $\begin{array}{l}\text { De/ } \\
\text { Or }\end{array}$ & 0.29 & 10 & $\begin{array}{l}\text { Fresh leaves are beaten on a swollen part } \\
\text { Roots' decoction is mixed with honey, Aloe sp roots } \\
\text { and herbal decoction, forming 'opururua' and drunk }\end{array}$ & $\begin{array}{l}\text { Reduces swelling } \\
\text { Diuretic/ cleanse kidney and build the body }\end{array}$ & RPC018 \\
\hline \multirow[t]{6}{*}{ Verbenaceae } & $\begin{array}{l}\text { Clerodendrum } \\
\text { johnstonii Oliv. }\end{array}$ & Olosholo & W & $\mathrm{Cl}$ & Rt & Or & 0.24 & 19 & $\begin{array}{l}\text { Root is boiled in water and the formed decoction is } \\
\text { drunk or mixed with meat broth/stock and drunk }\end{array}$ & $\begin{array}{l}\text { Diuretic/cleanse kidney, treats pain of back } \\
\text { and waist }\end{array}$ & RPCO01 \\
\hline & $\begin{array}{l}\text { Clerodendrum } \\
\text { myricoides } \\
\text { (Hochst.) Vatke }\end{array}$ & Orkibasirkon & w & $\mathrm{Sb}$ & LRt & Or & 0.24 & 14 & $\begin{array}{l}\text { Leaves are chewed and formed juice is swallowed or } \\
\text { the leaves are boiled in water and the formed } \\
\text { decoction is drunk }\end{array}$ & Cough and fever & RPC031 \\
\hline & & & & & & & & & $\begin{array}{l}\text { Roots' decoction is drunk or mixed with honey and } \\
\text { Aloe sp root then drunk. }\end{array}$ & Fever & \\
\hline & $\begin{array}{l}\text { Lippia javanica } \\
\text { (Burm f.) } \\
\text { Spreng. }\end{array}$ & Osinoni & W & $\mathrm{Sb}$ & Lf & & 1.71 & 57 & $\begin{array}{l}\text { Leaves are crafted or made into a mat ('enaraa') or are } \\
\text { wrapped on meat as a gift paper }\end{array}$ & $\begin{array}{l}\text { Hold animal/meat, prevent, contamination } \\
\text { and provide taste or flavor to the meat and } \\
\text { in the slaughtering process }\end{array}$ & RPC033 \\
\hline & $\begin{array}{l}\text { Lippia kituiensis } \\
\text { Vatke }\end{array}$ & Osinoni oriri & w & $\mathrm{Sb}$ & Rt & Or & 0.38 & 19 & $\begin{array}{l}\text { Roots' decoction is mixed with that of in Solanum } \\
\text { incanum roots \& Ocimum gratissimum roots, or with } \\
\text { meat broth/ stock or chicken broth or blood and drunk } \\
\text { or } \\
\text { With decoction of Cordia africana bark \& Chenopodium } \\
\text { schraderianum leaves then drunk and steamed on the } \\
\text { body }\end{array}$ & $\begin{array}{l}\text { Pain of joints, fever and 'OSUPETAl' } \\
\text { Measles }\end{array}$ & $\mathrm{RPCO40}$ \\
\hline & $\begin{array}{l}\text { Verbena } \\
\text { officinalis L }\end{array}$ & Engoombai & W-HG & $\mathrm{H}$ & Wp & Or & 0.10 & 5 & $\begin{array}{l}\text { Fresh aerial part is boiled in water and the formed } \\
\text { decoction is mixed with fresh milk and drunk }\end{array}$ & $\begin{array}{l}\text { Induces vomiting and detoxify a swallowed } \\
\text { poison }\end{array}$ & RPC045 \\
\hline
\end{tabular}




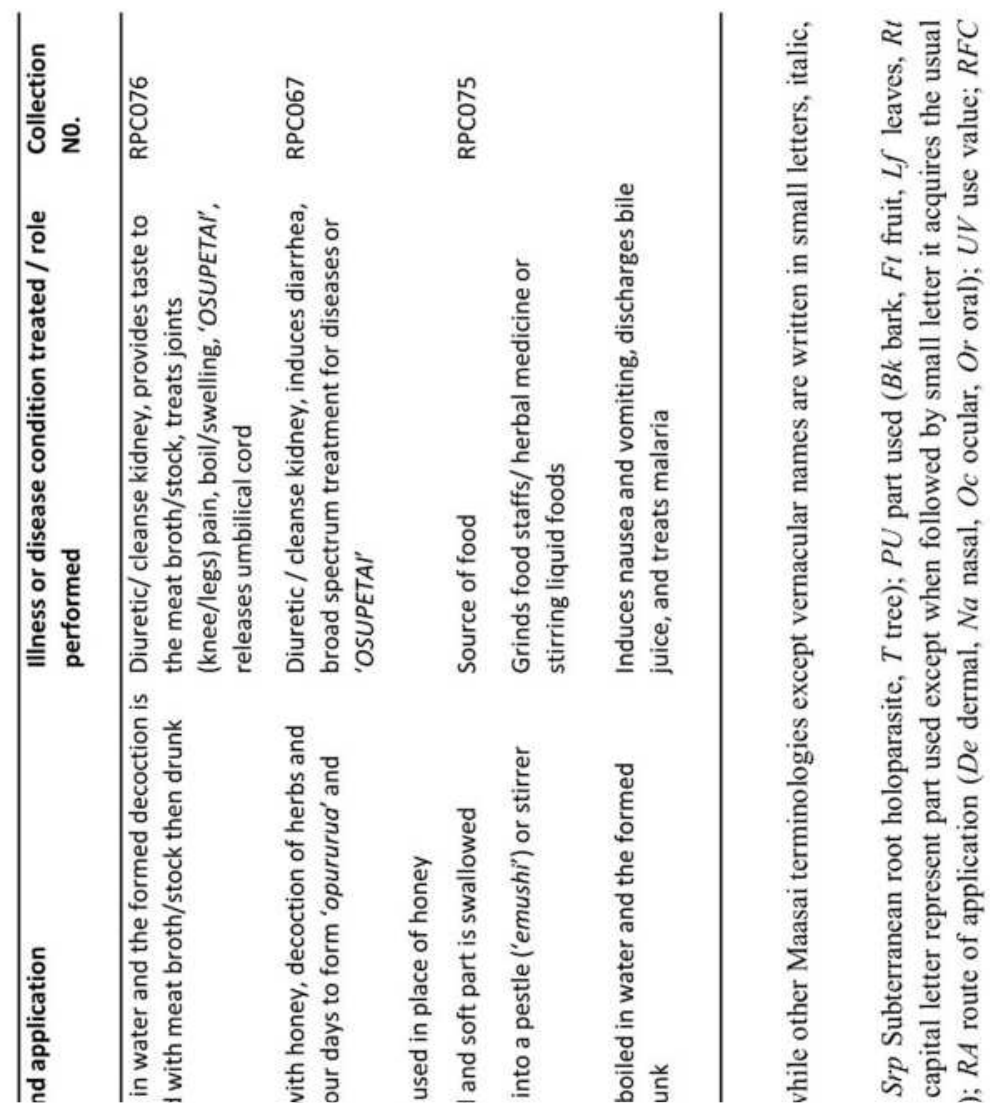

$\mathrm{d}$, route of administration, use value, relative frequency of citation, mode of preparation ra used by MSPs in Monduli Districts, Arusha, 2021 (continued)

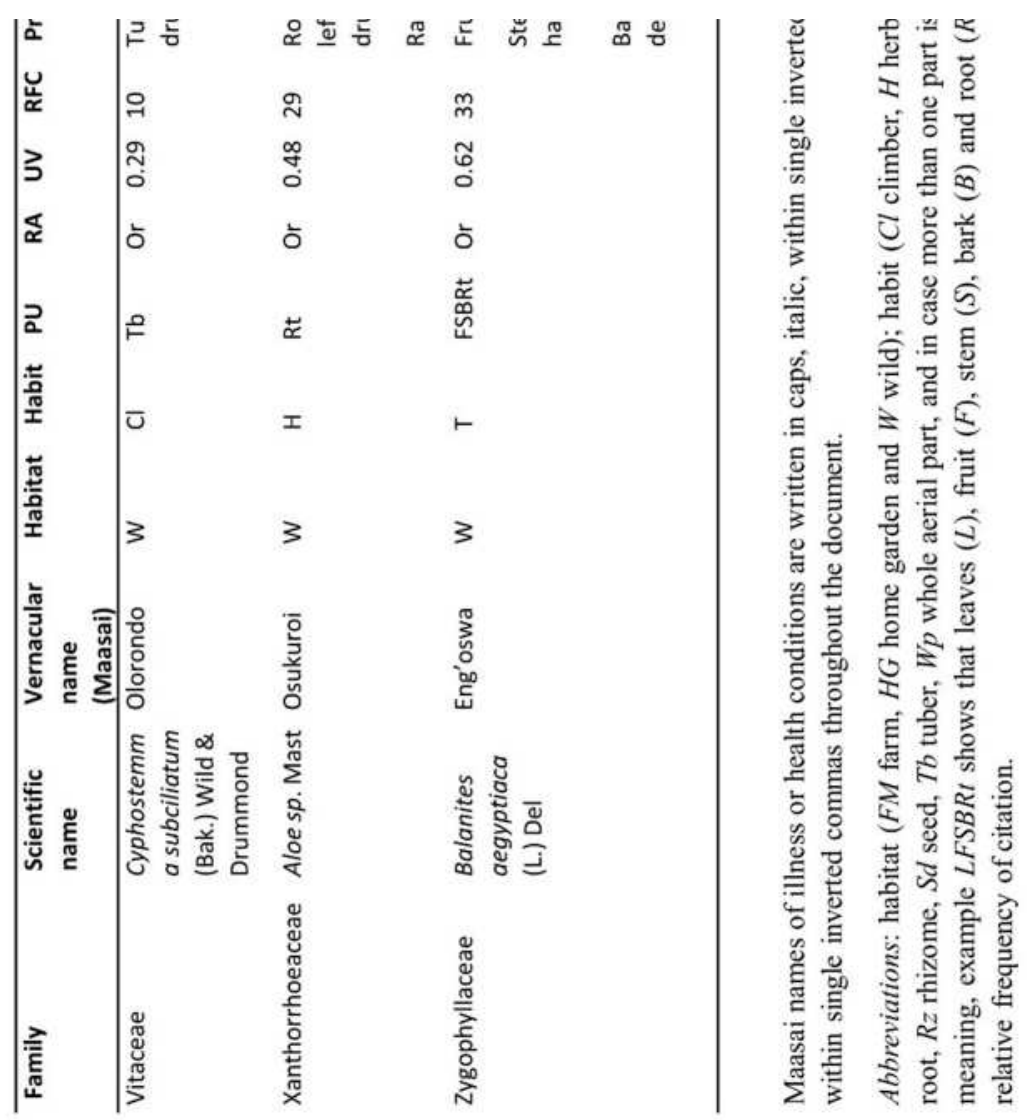


Table 3 Results of informants' consensus factor (ICF) for the illness treated or role performed by flora used in FS and TM by MSPs in Monduli District, Arusha

\begin{tabular}{|c|c|c|c|c|}
\hline $\mathbf{S} / \mathbf{N}$ & Disease (s) treated / role (s) performed & Number of $S p$ & Number of URPT & ICF \\
\hline 1 & Food preservation / taste / flavor & 4 & 43 & 0.93 \\
\hline 2 & Induces abortion / excess menstrual flow & 2 & 11 & 0.90 \\
\hline 3 & Stop thirst & 2 & 7 & 0.83 \\
\hline 4 & Food processing / storage material (s) & 32 & 169 & 0.82 \\
\hline 5 & Food & 29 & 135 & 0.79 \\
\hline 6 & Intestinal worms / parasites & 6 & 23 & 0.77 \\
\hline 7 & Increases confidence / angriness ('MORI') & 3 & 8 & 0.71 \\
\hline 8 & Increases libido / energy / strength & 3 & 8 & 0.71 \\
\hline 9 & Induces vomiting & 5 & 14 & 0.69 \\
\hline 10 & Constipation / releases stomach gas & 3 & 7 & 0.67 \\
\hline 11 & Cough & 6 & 16 & 0.67 \\
\hline 12 & Food digestion & 5 & 13 & 0.67 \\
\hline 13 & 'Opururua' / alcohol ingredient only & 3 & 7 & 0.67 \\
\hline 14 & Increases body temperature / sweating & 6 & 15 & 0.64 \\
\hline 15 & Induces diuresis / cleanse kidney & 32 & 84 & 0.63 \\
\hline 16 & Fever / malaria & 14 & 34 & 0.61 \\
\hline 17 & Measles & 3 & 6 & 0.60 \\
\hline 18 & Gonorrhea / syphilis & 16 & 38 & 0.59 \\
\hline 19 & Boil / edema & 14 & 33 & 0.59 \\
\hline 20 & 'OSUPETAI / 'OLGILA' & 33 & 78 & 0.58 \\
\hline 21 & Induces diarrhea & 13 & 29 & 0.57 \\
\hline 22 & Other Uses & 8 & 17 & 0.56 \\
\hline
\end{tabular}


Table 3 Results of informants' consensus factor (ICF) for the illness treated or role performed by flora used in FS and TM by MSPs in Monduli District, Arusha (continued)

\begin{tabular}{|c|c|c|c|c|}
\hline $\mathbf{S} / \mathbf{N}$ & Disease (s) treated / role (s) performed & Number of $S p$ & Number of URPT & ICF \\
\hline 23 & Flue & 5 & 10 & 0.56 \\
\hline 24 & Pain of back / waist / muscles / pelvis & 15 & 32 & 0.55 \\
\hline 25 & Food taste / flavour / viscosity / color & 13 & 27 & 0.54 \\
\hline 26 & Joint pain / Inflammation & 30 & 61 & 0.52 \\
\hline 27 & Hernia ('ENAPORSESENI') & 3 & 5 & 0.50 \\
\hline 28 & Increase / stop lactation milk & 2 & 3 & 0.50 \\
\hline 29 & Joins a broken bone / reliefs bones' pain & 7 & 13 & 0.50 \\
\hline 30 & Wound / ulcers & 7 & 13 & 0.50 \\
\hline 31 & Detoxification / anti-dote & 6 & 10 & 0.44 \\
\hline 32 & Uterus / pregnancy disorders / female infertility & 11 & 19 & 0.44 \\
\hline 33 & Stomachache / diarrhea & 13 & 21 & 0.40 \\
\hline 34 & Anti-coagulant & 3 & 4 & 0.33 \\
\hline 35 & Tiredness / body weakness & 9 & 13 & 0.33 \\
\hline 36 & Chest pain / infection / pneumonia & 9 & 12 & 0.27 \\
\hline 37 & Anaemia / increases blood & 2 & 2 & 0.00 \\
\hline 38 & Diabetes & 3 & 3 & 0.00 \\
\hline 39 & Headache & 2 & 2 & 0.00 \\
\hline 40 & Pressure & 3 & 3 & 0.00 \\
\hline 41 & Tonsillitis / lost singing voice & 2 & 2 & 0.00 \\
\hline 42 & Tooth pain / infection & 2 & 2 & 0.00 \\
\hline 43 & Bilharzia & 1 & 1 & \\
\hline 44 & Eyes' infection & 1 & 1 & \\
\hline
\end{tabular}

Abbreviation: $S p$, species; URPT, use reports; $I C F$, informants' consensus factor

\section{MPs Used in Management of Health Conditions Associated with Gout}

This section presents findings of health conditions associated with gout as reported by respondents as well as it was pointed out early in the background of this study. MPs used in the management of the health conditions are also presented in this section. The health conditions included 'OSUPETAI', inducing diuresis, joints' pain and inflammation, pressure, diabetes and digestive system disorders. Some of these health conditions were linked with gout condition by some MSPs. In this section, where necessary, MPs are presented in figures by their vernacular names and collections numbers which can be used to refers their scientific names in Tables 2. 
Thirty (30) species of MPs were reported to be used by MSPs in management of joints' pain and or inflammation at ICF of 0.52 (Table 2, Table $3 \&$ Fig. 7). This health condition was linked to gout by some respondents, only $2(9.52 \%)$ of the them who claim to know gout. The respondents reported that gout symptoms included pain and inflammation on joints such as knee, in step, fingers and ankles especially when stretching the joints, as well as difficult in walking and standing upright easily. The respondents further reported that gout is caused by age (getting older above 60-years), eating roast meat every day (particularly of goat) without taking any herbal medicine, adding salt to the meat and roasting it on metal wires. These symptoms were managed by the MPs as detailed in this section.

The most frequently used MPs in management of joints' pain was Rapanea melanophloeos (Iloodwa / Engodwai) with RFCs $=0.29$ and FL of 1.00; followed by Embelia schimperi (Olchani onyokie) and Withania somnifera (Olesayet) each having $\mathrm{RFC}_{s}$ of 0.24 and FL of 0.50; Combretum zeyheri (Ormaroroi-oibor) with $\mathrm{RFC}_{s}$ of 0.19 and FL of 0.80 ; and Commicarpus plumbagineus (Orng'eriandus), Croton megalocarpus (Ormarbait) and Harrisonia abyssinica (Endundulu) with $\mathrm{RFC}_{s}$ value of 0.14 each and FL of 1.00, 0.75, 0.38 respectively (Fig. 7).

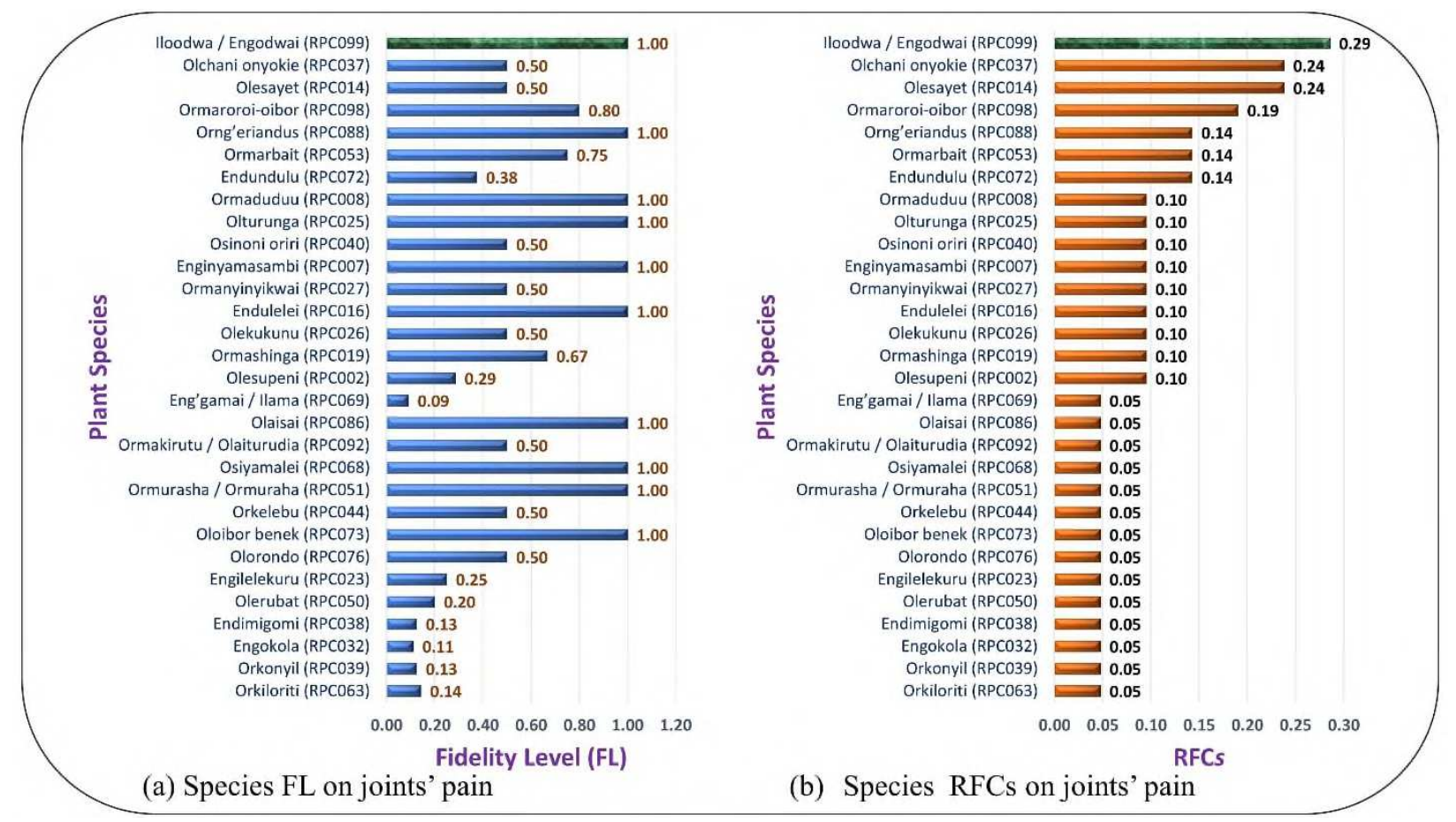

Figure 7 Fidelity level, FL (a) and specific relative frequency of citation, RFCs (b) of MPs used in management of joints' pain by MSPs 
Furthermore, this study found that 26.7\% (8 species) of the MPs used in management of joints' pain were also used in the management of joints' inflammation. The species had ICF of 0.50 in management of joints' inflammation. The most commonly used MPs in management of joints' inflammation was Withania somnifera (Olesayet) with RFCs and FL of 0.24 and 0.50 respectively. This was followed by Caesalpinia decapetala (Ormashinga), Commicarpus plumbagineus (orng'eriandus) and Embelia schimperi (Olchani onyokie) with $\mathrm{RFC}_{s}$ of 0.10 each and FL of 0.67, 0.67 , and 0.20 respectively. The other MPs used in management of joints' inflammation were Acacia sp. (Osiyamalei), Cyphostemma subciliatum (Olorondo), Harrisonia abyssinica (Endundulu) and Rhamnus staddo (Engokola), and with $\mathrm{RFC}_{s}$ value of 0.05 each, and FL value of 1.0, 0.5, 0.13, and 0.11 respectively (Fig. 8). These MPs used in management of joints' inflammation were also used in joints' pain management (Table 2).

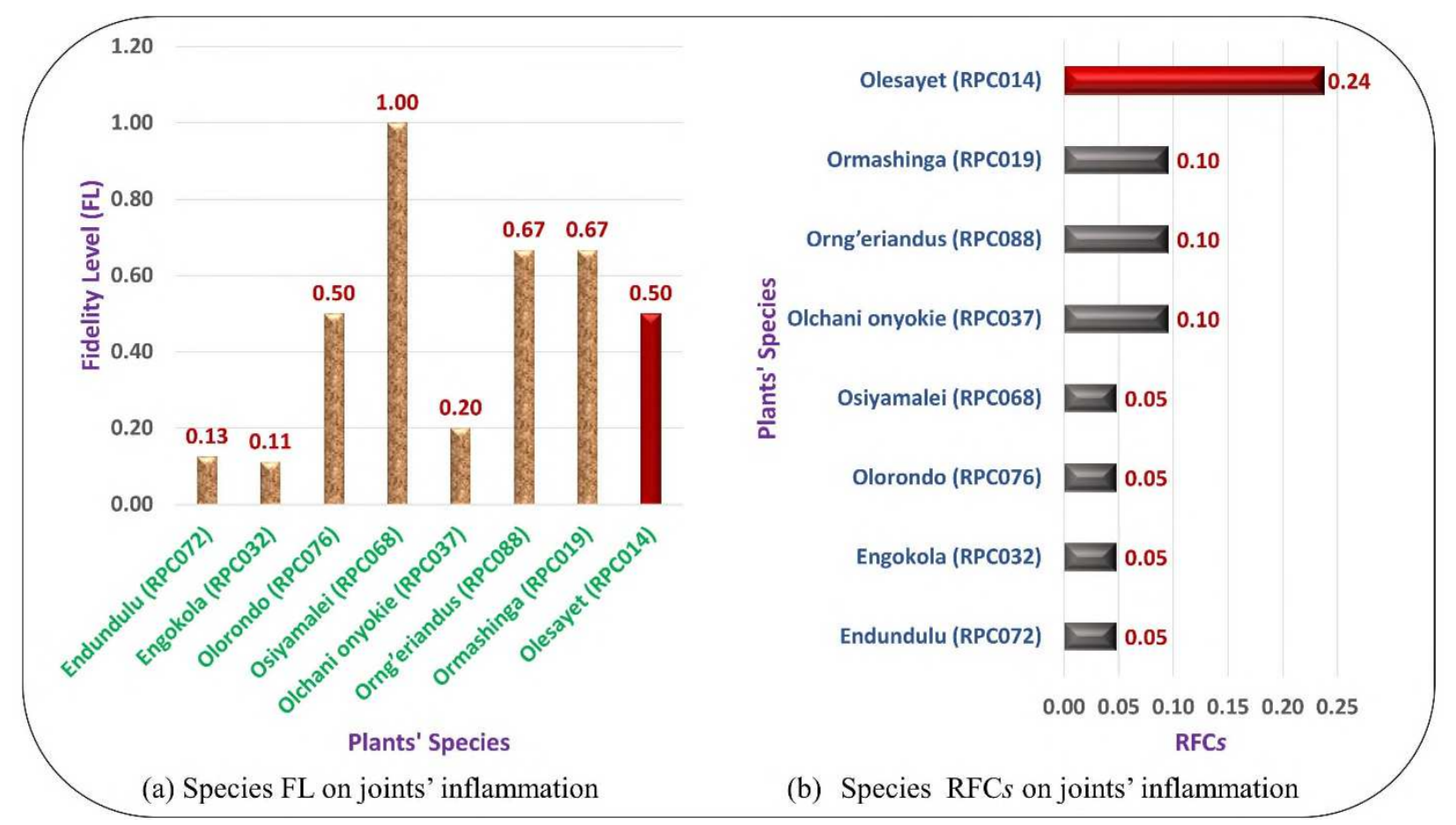

Figure 8 Fidelity level, FL (a) and specific relative frequency of citation, RFCs (b) of MPs used in management of joints' inflammation by MSPs.

Moreover, 33 MPs were reported to be used in management of 'OSUPETAI' or 'OLGILA' with ICF of 0.58 (Table 3). The most commonly used MPs in treatment of 'OSUPETAI' or 'OLGILA' was Withania somnifera (Olesayet) with $\mathrm{RFC}_{s}$ and FL values of 0.43 and 0.9 respectively; 
followed by Aloe sp Mast (Osukuroi), a common ingredient in 'opururua' (Table 2) with RFCs and FL value of 0.29 and 1.00 respectively.

On the other hand, $66.7 \%$ (22 species) of the MPs, used in the management of 'OSUPETAI' or 'OLGILA' were also found to be used in the management joints' pain and or inflammation. These species had ICF of 0.63 in management of 'OSUPETAI' or 'OLGILA'. In this case the most frequently used MPs in management of 'OSUPETAI' or 'OLGILA' was Withania somnifera (Olesayet) with $\mathrm{RFC}_{s}$ and FL values of 0.43 and 0.9 respectively; followed by Rapanea melanophloeos (Iloodwa), Rhamnus Prinoides (Orkonyil), and Harrisonia abyssinica (Endundulu) with $\mathrm{RFC}_{s}$ of 0.24 each, and FL value of $0.83,0.63$, and 0.63 respectively (Fig. 9); Lepidotrichilia volkensii (Engilelekuru) and Embelia schimperi (Olchani onyokie) with $\mathrm{RFC}_{s}$ of 0.19 each, and FL value of 1.00 and 0.40 respectively; and Combretum zeyheri (Ormaroroi-oibor) with $\mathrm{RFC}_{s}$ and FL value of 0.14 and 0.60 respectively (Fig. 9). The remaining MPs used in the management of 'OSUPETAI' or 'OLGILA' are detailed in (Table 2 \& Fig. 9).

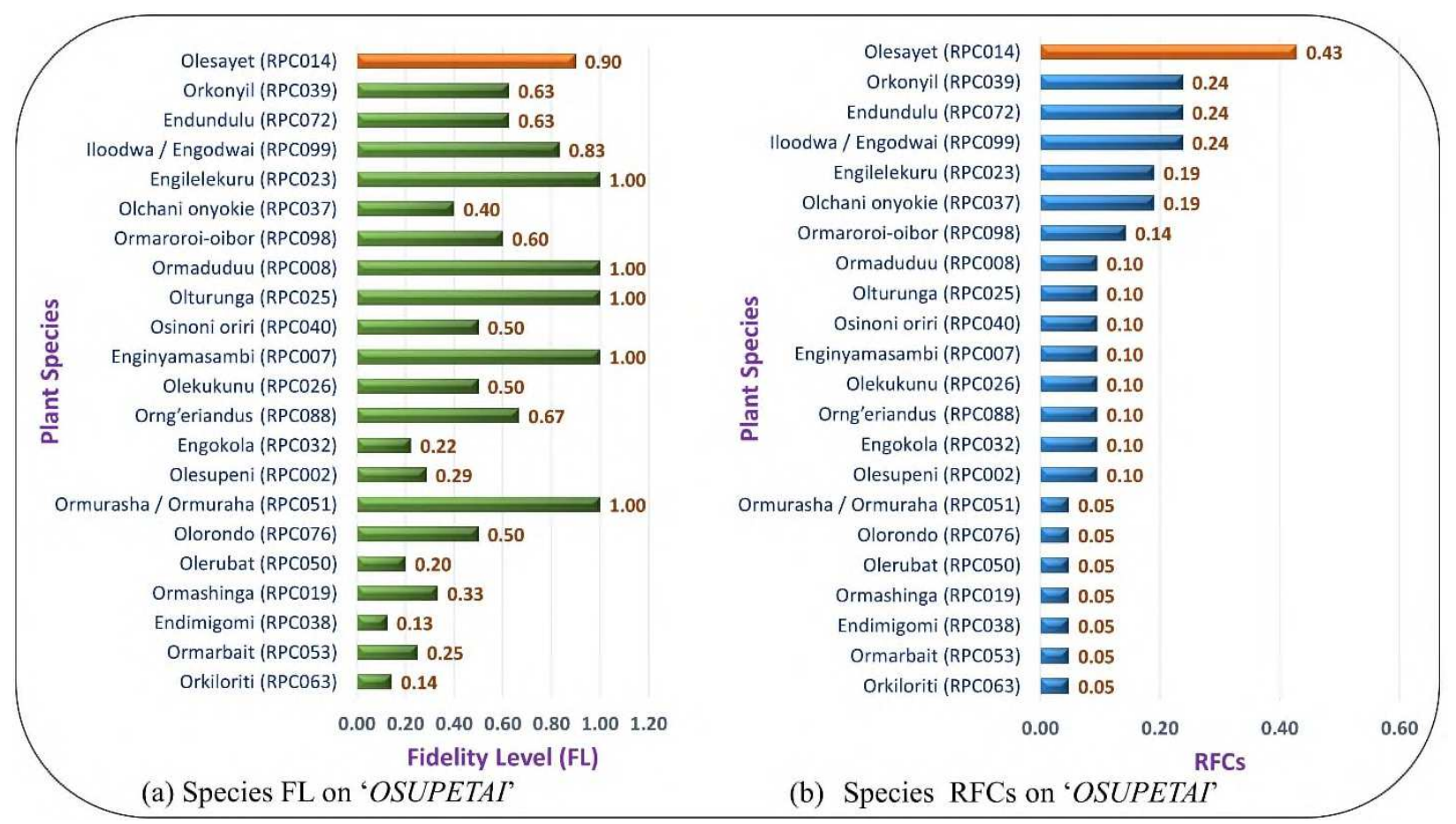

Figure 9 Fidelity level, FL (a) and specific relative frequency of citation, RFCs (b) of MPs used in management of 'OSUPETAI' by MSPs. 
Equally, 32 MPs (Table 2) were found to be used by MSPs in inducing diuresis (cleanse kidney) with ICF of 0.63 (Table 3) while 59.4\% (19 species) of the MPs were also used in treatment of joints' pain and or inflammation. The most commonly used MPs in inducing diuresis was Withania somnifera (Olesayet) with RFCs and FL value of 0.43 and 0.90 respectively. This was followed by Rhamnus Prinoides (Orkonyil) with RFCs and FL value of 0.33 and 0.88 respectively; Iloodua and Rhamnus staddo (Engokola) with RFCs of 0.24 each and FL value of 0.83 and 0.56 respectively; Chenopodium schraderianum (Olekukunu) and Piper capense (Olerubat) with RFCs of 0.19 each and FL value of 1.00 and 0.80 respectively; Helinus mystacinus (Olesupeni) and Acacia nilotica (Orkiloriti) with RFCs of 0.14 each and FL value of 0.43 each (Fig. 10). These MPs were also used in treatment of joints' pain and or inflammation. Besides, other MPs commonly used in inducing diuresis but not reported in treating joints' pain and or inflammation included Vepris simplicifolia $(\mathrm{RFC} s=0.24 ; \mathrm{FL}=0.63)$, followed by Carissa spinarum $(\mathrm{RFC} s=$ $0.19 ; \mathrm{FL}=0.67)$, and Scutia myrtina $(\mathrm{RFC} s=0.14 ; \mathrm{FL}=0.50)$. The remaining MPs that induce diuresis are detailed in (Table 2 and Fig. 10).

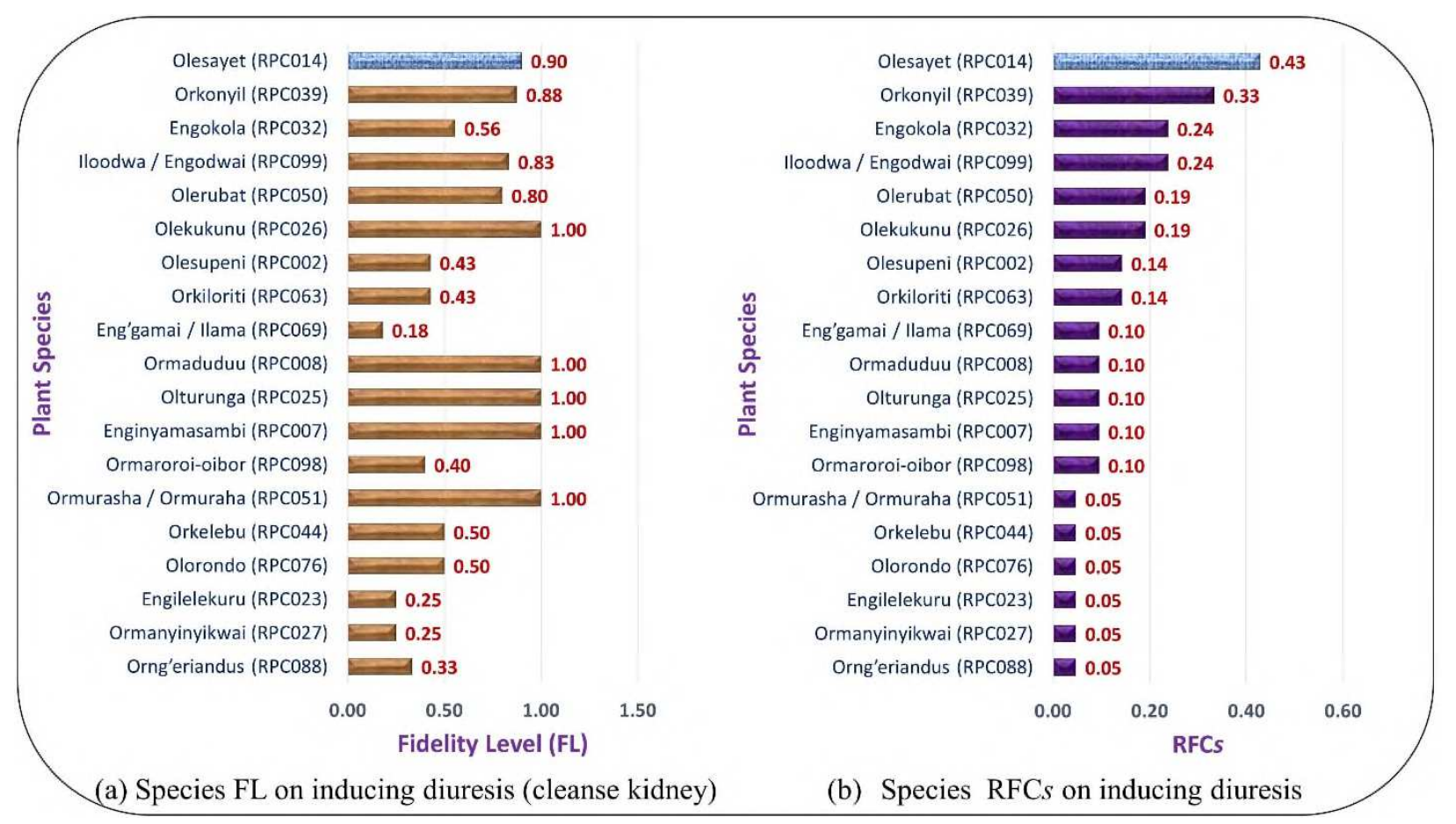

Figure 10 Fidelity level, FL (a) and specific relative frequency of citation, RFCs (b) of MPs used to induce diuresis (cleansing kidney) by MSPs 
Besides, this study recorded three (3) MPs used in treatment of blood pressure and diabetes. These plants included Asparagus setaceus, Tragia ukambensis and Hydnora abyssinica with ICF of zero (0) in treatment of the disease conditions. The MPs were used in combination to treat pressure and diabetes (Table 2)

In addition, other MPs were used in treatment of constipation or stomach gas and food digestion disorders. Three (3) species of MPs were used in treatment of constipation and stomach gas or bloating at ICF of 0.67 ; whereas, the most frequently used MPs, was Physalis peruviana $(\mathrm{FL}=$ 1.00; RFCs $=0.14)$ followed by, Ocimum gratissimum $(\mathrm{FL}=0.75 ; \mathrm{RFC} s=0.14)$ see (Table 2 and Table 3). On the other hand, food digestion was facilitated by five (5) species (Table 2) with ICF of 0.67 (Table 3); whereas, Acacia nilotica $(\mathrm{FL}=1.00 ; \mathrm{RFC} s=0.33)$ was the most frequently used MP.

\section{Market value of the flora used in Maasai FS and TMs}

Market survey was conducted in the selected common open markets which included, Makuyuni, Monduli, Meserani, and Ngaramtoni to assess the market value of the flora cited in the interviews conducted at the respondents' residence (figure 1). The findings showed that the majority (66.7\%) of flora observed in the open markets were cited during the interviews and collected from the field around the respondents' residence area. The remaining $(33.3 \%)$ of the observed flora were cited in the interviews done at the respondents' residence but their sample and voucher specimens were not collected for identification due to the reasons that were out of rich of this study. Flora observed in the open markets their parts were sold for medicinal purposes. Most of the medicinal purposes to which each floral part was sold, it was the same as that reported in the interviews done at the respondents' residence, except Acacia nilotica was reported to additionally be used for cleaning blood (Table $2 \&$ Table 4). This survey also showed that some MPs used in management of joints' pain and inflammation occupy space in the market and are one of the commodities with value in the open markets (Table 4). 
Table 4 Description on parts used, purpose of selling for the floral parts sold at Ngaramtoni, Makuyuni, Meserani and Monduli open markets in the study area.

\begin{tabular}{|c|c|c|}
\hline Medicinal Plants (MPs) & Part used & Purpose of Selling \\
\hline Acacia nilotica (Orkiloriti) & Bark (Bk) & Clean blood, increases 'MORI' and strength \\
\hline \multirow[t]{2}{*}{ Albizia anthelmintica (Emukutan) } & Bark (Bk) & $\begin{array}{l}\text { Treats intestinal parasites (worms), 'OSUPETAI', fever, boil or swelling, and } \\
\text { gonorrhea, anti-dote for a swallowed poison, increases body heat }\end{array}$ \\
\hline & & Note: The MP induces vomiting and diarrhea \\
\hline Clerodendrum myricoides (Orkibasirkon) & Root (Rt) & Treats cough and fever \\
\hline \multirow[t]{2}{*}{ Embelia schimperi (Olchani onyokie) } & Bark (Bk) & $\begin{array}{l}\text { Treats pain of joints, back, muscles and ribs, 'OSUPETAI' or 'OLGILA', } \\
\text { boil, gonorrhea, joints' inflammation, stomachache, flue, cough and fever }\end{array}$ \\
\hline & & $\begin{array}{l}\text { Note: The MP induces diarrhea and abortion or excess menstrual flow (not } \\
\text { suitable for women at reproductive age) }\end{array}$ \\
\hline Engong'otutisho & Root (Rt) & $\begin{array}{l}\text { Relief muscles ('oseseni') pain, pain of the back, waist, joints, body } \\
\text { weakness, treats gonorrhea, syphilis, induces diuresis and diarrhea }\end{array}$ \\
\hline Hydnora abyssinica (Erukunyi) & Rhizome (Rz) & Stomachache or ulcers \\
\hline Lannea schweinfurthii (Orupande) & Bark (Bk) & $\begin{array}{l}\text { Clean uterus, stop excess menstrual flow/pregnancy bleeding and pain, relief } \\
\text { its pain }\end{array}$ \\
\hline Lepidotrichilia volkensii (Engilelekuru) & Root (Rt) & Treats Joints' pain, 'OSUPETAI' \\
\hline Leucas sp (Enjaniengusero) & Leaves (Lf) & Stomachache \\
\hline Ndukushi & Tuber $(\mathrm{Tb})$ & Induces vomiting of bile juice or treats malaria \\
\hline
\end{tabular}


Table 4 Description on parts used, purpose of selling for the floral parts sold at Ngaramtoni, Makuyuni, Meserani and Monduli open markets in the study area (continued)

\begin{tabular}{|c|c|c|}
\hline Medicinal Plants (MPs) & Part used & Purpose of Selling \\
\hline Oltang'oruwa & Root (Rt) & $\begin{array}{l}\text { Increases ' } M O R I \text { ' or confidence, make meat soup viscous, causes sweating, } \\
\text { raises body temperature, immunity and energy }\end{array}$ \\
\hline Oremiti & Stem (St) & Tooth brush \\
\hline Orkitalaswa & Bark (Bk) & $\begin{array}{l}\text { increases 'MORI', clean stomach, treats cough, 'OSUPETAI' (caused by } \\
\text { roast food), inflammation or edema on knee, fingers, toes }\end{array}$ \\
\hline Ortarakwai & Stem (St) & Stem smoke treats headache \\
\hline Osokonoi & Bark (Bk) & Treats cough, pneumonia, asthma, fever/malaria \\
\hline \multirow[t]{2}{*}{ Rapanea melanophloeos (Iloodwa) } & Fruit $(\mathrm{Ft})$ & $\begin{array}{l}\text { Treats gonorrhea, internal wounds, intestinal parasites (worms), } \\
\text { 'OSUPETAI', joints pain, induce diuresis }\end{array}$ \\
\hline & & Note: The MP can induce diarrhea \\
\hline Rhamnus Prinoides (Orkinyil) & Root (Rt) & $\begin{array}{l}\text { Treats pain of joints, boil/swelling, gonorrhea, reliefs tiredness or body } \\
\text { weakness and increases body heat, induces diuresis }\end{array}$ \\
\hline Rhamnus staddo (Engokola) & Root (Rt) & Treats 'OSUPETAI', broken bones \\
\hline Secamone parvifolia (Osinandei) & Root (Rt) & Clean uterus, reliefs womb/uterus pain \\
\hline Vepris simplicifolia (Olgilai) & Root (Rt) & Treats fever, gonorrhea, intestinal parasite (worms) and 'OSUPETAI' \\
\hline Zanthoxylum chalybeum (Oloisuki) & Root (Rt) / Bark (Bk) & Treats fever, cough and flue \\
\hline Zanthoxylum deremense (Oloisuki) & Root (Rt) / Bark (Bk) & Treats fever, cough, and flue \\
\hline
\end{tabular}

\section{Discussion}

Flora used in indigenous food systems (FS) or traditional medicine (TM) have been playing an important role in promoting individual health and well-being particularly in the disadvantaged communities across the word [1,2]. Such flora is vital and often undervalued part of health care, and their application in indigenous FS or TM is evident in almost every country in the world $[1,2,4,5]$. The demand for its services is currently increasing mainly in form of alternative nutraceuticals or medicine. It is the main source of healthcare, and sometimes the only source of care, due to its closeness to the ordinary rural communities and its accessibility and affordability in view of the rising of healthcare costs $[1,2,4,5]$. The use of such flora has been linked to some of 
the diseases for instance gout, being uncommon in certain communities like Maasai with strong uphold of cultural values in their FS and TM, though, they are exposed to similar risk factors like other communities with no such values where the disease is common. Tanzanians particularly Maasai to a large extent depend on flora used in indigenous FS and TM for their primary health care due to limited access to functional modern healthcare facilities, affordability, cultural acceptability of traditional medicine practices and practitioners, perceived efficacy against certain types of diseases, and the belief that such flora has low side effects [2,4,5,27]. As a result of improved access to contemporary medicine, poor relation between young and old generation, environmental degradation such as overgrazing, over exploitation of natural resources, and urbanization, both traditional knowledge and flora that have been used in indigenous FS and TM, for millennium are highly threatened [1].

Despite of such threats contributed mainly by the anthropogenic activities, there are still many flora in different part of Tanzania [7,8,10,11]. The findings of the current study conducted in Monduli District and some part of Arusha rural, have recovered a total of 101 flora with various uses. It was found that medicinal uses accounted for 53.69\% (80 species). This was followed by food processing and storage, 21.48\% (32 species); food sources 19.46\% (29 species); and other uses such as glue, soap, veterinary and ritual purpose, 5.37\% (8 species). Furthermore, it was observed that some of the flora particularly MPs with the most common uses and some with low or no availability in some places of the study area, were found to be sold in opens markets. This observation justifies the traditional healthcare and economic importance of the MPs. The findings of this study suggest that the study area has large biodiversity of flora that are main source of medicine, food, food processing and storage materials and other uses, as well as it plays its role in income generation. Therefore, protection and sustainable use of such biodiversity is inevitable.

Furthermore, it was found that trees accounted for a higher proportion of the flora used in the study area. This observation was also made in Maasai of Southern Kaijiado District, Kenya [28]. This could be attributed to the common cultural reflections and pattern of growth forms in Maasai communities.

This study also revealed that families Euphorbiaceae and Fabaceae ( 8 species each); followed by Solanaceae (6 species); Boraginaceae, Rhamnaceae, Rutaceae and Verbenaceae (5 species each); Anacardiaceae ( 4 species) comprise a greater number of flora species. These are among the 
topmost families comprising flora used mainly as MPs in different parts of the country, and their higher proportion in the flora of Tanzania substantiates this report, implying documentation of wide distribution and higher number of species of these families throughout the country [7,8,11].

Still, it was found that mostly widely used part of the flora used in the Maasai FS and TM was root accounting for 55 species with $30.73 \%$ of uses and 213 use reports. The study by Ngowi et al reported similar findings with medicinal plants of Kondoa [8]. Possible explanation for this observation is that Maasai people like Rangi people through their long experiences have been able to ascertain that roots were the most effective plant part. The observation is scientifically supported by Ngowi et al., reporting that alkaloid composition of Strychos species in South America was two folds higher in roots and barks relative to the amount found in leaves [8]. It can therefore be concluded that roots play an important role especially in the indigenous healthcare systems for management of various health conditions. Though, exploitation of the roots and barks poses more threats to the flora than the use of other parts [27].

Moreover, it was found that more of the flora were used in the Maasai TM as MPs than other use categories as indicated by the high proportion of species, 80 out of 101 species recorded in this study. This suggest that the flora of the study area play a significant role in management of various health conditions as detailed in table 2. Out of these MPs some were used to manage symptoms and related health conditions of gout, a disease claimed to be uncommon in Maasai community embracing their cultural values in FS and TM.

Treatment of joints' pain and inflammation was among the medicinal function achieved by the MPs used by MSPs. The joints' pain and inflammation are among the important symptoms of gout in addition to the deposition of monosodium urate in the affected joints, which often is determined clinically $[29,30]$.

It was revealed that, 37.5\% (30 species) of the MPs were used in management of joints' pain and or inflammation while $10.0 \%$ of the MPs were used in management of both joints' pain and inflammation. On one hand, the most frequently used MPs in the management of joints pain was Rapanea melanophloeos, followed by Embelia schimperi and Withania somnifera, Combretum zeyheri, Commicarpus plumbagineus, Croton megalocarpus and Harrisonia abyssinica. On the other hand, the most frequently used MPs in management of joints' inflammation was Withania somnifera, followed by Caesalpinia decapetala and Commicarpus plumbagineus, Embelia 
schimperi, Acacia sp. (Osiyamalei), Cyphostemma subciliatum, Harrisonia abyssinica and Rhamnus staddo. These species were also used in management of joints' pain. This finding suggests that the most common MP in treating both joints' pain and inflammation is Withania somnifera.

The use of MPs in management of joints' pain and inflammation in the current study is supported by findings of some other ethnomedicinal studies. Pappea capensis and Rhamnus prinoides were reported to be used traditionally in the treatment of arthritis or gout [28,31]. Moreover, Acacia nilotica was reported to treat painful joints while Rhamnus staddo treat joints pain, inflammation, gout, and clean kidney [32,33]. Also, Commicarpus plumbagineus is used in treatment of arthritis [34].

Still, findings of some pharmacological studies support the traditional use of the MPs in treatment of joints' pain and inflammation. Withania somnifera is the well-known important medicinal plant in Indian system of medicine for treating many ailments since time immemorial [35,36]. This concur with its highest use value $(\mathrm{UV}=2.67)$ recorded in this study. Moreover, pre-clinical studies of Withania somnifera has shown anti-inflammatory, anti-diabetic, anti-microbial, anti-stress, antitumor, cardioprotective, neuroprotective properties as well as ability to reduce reactive oxygen species, modulate mitochondrial function, regulate apoptosis, reduce inflammation and enhance endothelial function [35,36]. Moreover, Caesalpinia decapetala, Rhamnus prinoides and Harrisonia abyssinica are reported to have antioxidant or anti-inflammatory activities [37-41]. Species with antioxidant or free radical scavenging, anti-inflammatory and xanthine inhibitory activity are known to be the best choice of bioactive agents in treatment of gout $[15,30,42,43]$. Furthermore, phenolic compounds are known to have anti-hyperuricemia or anti-inflammatory activities [40,43]. Thus, the use of such MPs by Maasai while they are health or sick in their FS and TM, could support the claim that gout is not common in the Maasai community. Such species used in management of joints pain and inflammation have potential contribution in the discovery of drugs against gout.

Furthermore, this study revealed that some MPs were used to treat illness or manage health conditions that are uniquely defined by the MSPs as well as some related to or share some symptoms and causes of gout. These illness or health conditions included 'OSUPETAI' or 'OLGILA', blood pressure, diabetes, diuretic process, and digestive system disorders. 
'OSUPETAI' and 'OLGILA' are sometimes interchangeably used by MSPs to refers the same health condition. 'OSUPETAI' which is sometimes referred to as 'TAMBAZI' in Swahili by most of MSPs, was identified by symptoms and causes described by the respondents; however, the symptoms and causes of the health condition are supported by clinical literature and findings.

Reported symptoms of 'OSUPETAI' included pain and inflammation of joints like ankle, finger and knee, and sometimes sudden and severe pain and warmth inflammation on the joints that occurred at specific time (particularly at night). All of these symptoms are the clinical representation of gout [18]. Furthermore, a swelling of the skin occurring on an area such as nipple or leg and that develop an opening and accumulation of pus was another reported symptom and claimed to represent boil which in Swahili was termed as 'JIPU' and clinically is known to be caused by Staphylococcus aureus infection [44].

Still, obstructed urination associated with pain and discharge of blood and pus from the penile or vagina were also reported as symptoms of 'OSUPETAI' as well as claimed to signify gonorrhea, a clinical illness represented by the symptoms [45,46]. However, other infections such as chlamydia and Trichomonas may share the same symptoms of gonorrhea $[47,48]$. Moreover, a swelling when pressed retains dimples or pits was reported as another symptom of the disease which also is a clinical representation of edema [49-51]. In addition, other symptoms of 'OSUPETAI' included pain on muscles, waist and back, which clinically may be caused by muscle and ligament strain, bulging or ruptured disks, arthritis or osteoporosis [52,53].

Likewise, reduced libido was one of the reported symptom of 'OSUPETAI' and clinically has different interplaying causes that involves internal cognitive processes, neurophysiological mechanisms and affective [54-58]. Similarly, body weakness and fatigue are claimed symptoms of the health condition. Clinical causes of body weakness could be infectious, inflammatory, endocrine, genetic, metabolic, neurologic, rheumatologic, electrolyte-induced, or drug-induced [59]. While fatigue could due to physiological states, medical conditions, psychiatric disorders or medical prescriptions $[60,61]$

Equally pain and coldness feeling to the bones in cold weather were reported symptoms of 'OSUPETAI' and clinically are explained by some theories which have not yet pinpoint the actual cause of the situation: one theory explaining that inactiveness due to cold weather lower blood circulation to organs and bones hence pain and weakness to the joints; and the other theory 
explaining that barometric pressure changes in cold weather may have an effect to the tendons, muscles, scar tissue or exposed nerves of the bone, that results into bones and joints pain especially to those people with arthritis $[62,63]$

Tonsillitis was another reported manifestation of the health condition; whereas, common virus or bacteria are the clinical causes of the illness [64-66]. Swelling of the tooth gum was also recognized as a symptom of 'OSUPETAI'; whereas, the underlying causes include poor dental hygiene and periodontal infections particularly with [67,68]. Lastly, but not least one-sided headache in cold weather was reported as the symptom of 'OSUPETAI' and it is a clinical sign of migraine where its pathogenesis is suggested to represent vascular phenomenon or a neurovascular disturbance, relating to changes in brain and genes [69-71]

Furthermore, MSPs reported causes or risk factors of 'OSUPETAI'; whereby, the most common risk factor was sexual intercourse between infected partners who could either be a virgin woman, a woman in her menstrual cycle, a prostitute men or women. This risk factor coincides with the reported symptoms particularly those of gonorrhea or sexually transmitted disease gonorrhea [4548]

Small worms in Swahili referred to as 'Minyoo ya Safura' was also reported as the cause of the 'OSUPETAI' represented by edema. Though, the worms clinically known to causes anemia 'Safura' include, Necator americanus and Ancylostoma duodenale and in severe case could result into heart failure and widespread tissue swelling [72-75]. Nevertheless, other worms predominantly Wuchereria bancrofti and to some extent Brugia malayi and Brugia timori are clinically known to cause lymphedema in filariasis with no or less effect on hemoglobin content and anemia, contrary to the reported ones in anemia 'Safurra' case[76,77]. Consequently, the reported edema as one of 'OSUPETAI' symptom may be linked to the reported and clinical worms associated with anemia and lymphedema.

Moreover, drinking of sweetened drinks such as soda or eating roast food such as meat or lack of exercise were other reported causes of 'OSUPETAI' and clinically they represent some risk factors of gout disease [18]. Besides, eating food without taking herbal medicine or cleaning the body through diarrhea or frequent urination were reported causes of 'OSUPETAI' and this claim agrees with orpul festival of meat eating and healing by MSPs with one of the intentions being disease prevention and treatment [6]. 
In view of the reported and clinical symptoms, causes and risk factors of 'OSUPETAI' it is clear that the health condition or the term represents collection of illness affecting human with different causes including infectious pathogens and non-infectious agents which locally cannot be determined with certainty rather their symptoms are linked to their risk factors. This fact also supports the claim by one of the respondents saying 'OSUPETAI' is a collection of diseases'; thus, it was classified into bone ('loloik' in Maasai), muscles, joints, and urinary tract/gonorrhea 'OSUPETAI' depending on the part of the body affected. In addition, 'OSUPETAI' share common risks factors and symptoms of gout among other illnesses related to the reported health condition. Additionally, 'OLGILA' was another health condition reported by MSPs and has different symptoms representing the disease. Body weakness and pain on joints such as knee, fingers as well as pain of the back and waist were the most common symptoms of the health condition. As discussed early, the pain on joints are among the clinical signs of arthritis or gout [18]. Still, the pain on the back are the symptoms of the condition and have the same clinical etiologies as that described in 'OSUPETAI' [52,53]. Moreover, body weakness as the symptom of 'OLGILA', has the same clinical causes as described in the 'OSUPETAI' condition [59].

Furthermore, MSPs reported different causes of 'OLGILA'. Modern way of roasting meat which involve the use of salt and direct fire resulting into smoke and ashes on the meat was one of the reported causes. This is partly and clinically known to cause gout from the purine content of the meat and probably the added salt as the purine metabolism result into monosodium urate formation, a condition for the development of gout which is characterized by pain and inflammation of the joints [18] which also, they fairly represent the reported symptoms of 'OLGILA'. Moreover, lack of exercise or eating without working were other causes of the disease condition and clinically may result into body weakness and obese respectively. Obesity is the risk factor for many diseases including gout, diabetes and pressure [18]. Coldness weather was also the reported cause of 'OLGILA' as in 'OSUPETAI' condition with the same clinical justifications $[62,63]$.

Therefore, in accord to the reported causes, risks factors, symptoms of 'OLGILA' and their clinical justifications it is clear that the disease shares some common risk factors, causes and symptoms of gout that are the subset of causes, risk factors and symptoms of 'OSUPETAI'. However, in assessing the risk factors and causes of 'OLGILA' they seem to closely relate to gout, despite other 
diseases may bear the same risks factors and causes as discussed early. Furthermore, the sharing of common causes, risk factors and symptoms between 'OSUPETAI' and 'OLGILA' justifies their interchangeable use by some MSPs to refers the same health condition. Thus, the MPs used in management of 'OSUPETAI' could sometimes be used to manage 'OLGILA' as well as gout particularly for the shared causes and symptoms.

In this study it was found that the most commonly used MP in the management of 'OSUPETAI' or 'OLGILA' was Withania somnifera, followed by Rapanea melanophloeos, Rhamnus Prinoides and Harrisonia abyssinica, Lepidotrichilia volkensii, Embelia schimperi, and Combretum zeyheri. About, 66.7\% (22 species) of the MPs used in management of 'OSUPETAI' or 'OLGILA', were also used in management of joints' pain and inflammation (gout symptoms); whereas, most respondents agreed on the use at ICF of 0.632. Furthermore, most of the MPs used in management of 'OSUPETAI' or 'OLGILA', their different parts were combined to make preparations such as 'Opururua' or a mixture of herbal decoctions and meat broth or stock (Table $2 \&$ fig 5) for prevention and treatment of the health condition as described in Table 2. This practice can be justified by the fact that 'OSUPETAI' is the collection of diseases or illness as discussed early; thus, it may require different herbs with different role to realize effective prevention or treatment of the health condition. The practice of combining herbs is reported to be very common in 'orpul' festival of meat eating and healing; though, in some cases few plants can be combined or used alone in the treatment of specific illness with characteristics symptoms. For instance, one respondent combined Eucalyptus saligna and Ocimum gratissimum in preparing the decoction mixture to treat joints (finger \& knee) pain, claimed to occur during the night and reported as early signs of 'OSUPETAI'. Another respondent used Combretum zeyheri alone when he had experience of joints pain which was claimed to be caused by eating roast meet for long time without taking herbs.

Still, use of the MPs in management of 'OSUPETAI' or 'OLGILA' with its characteristics causes, risk factors and symptoms is supported by findings of other studies. Withania somnifera with its broad spectrum biological activities [35,36] could be responsible in management of symptoms and the underlying causes of 'OSUPETAI' or 'OLGILA'. In addition, Rapanea melanophloeos and Embelia schimperi are reported to have activity against parasitic worms or microbes [78-80], the possible underlying causes of 'OSUPETAI' or 'OLGILA'. 
This study further recorded MPs used in management of other illnesses or health conditions associated with gout. Pressure and diabetes were among illness treated by the MPs, and are clinically known to be the risks factors for the development of gout [18]. Each of the diseases was treated by a combined therapy from Asparagus setaceus, Tragia ukambensis and Hydnora abyssinica. However, the homogeneity of the knowledge were lacking as ICF on the use of the species in treatment of each disease was zero (0), this may be due to randomly choice of the species or no exchange of information about the use of the MPs on each disease or disagreement among the informants attributed by different experiences and keeping the information with strict secrecy [24,27]. Despite lacking of homogeneity on the use of the MPs in treating pressure and diabetes, these species have potential contribution for discovery of pressure and diabetes drugs as well as reducing the co-morbidities or the risk factors from the disease associated with gout.

Moreover, some MPs were used to induce diuresis or frequent urination which clinically is known to have effect on the gout health condition. Diuretics are known for helping the body to get rid of salt and water by stimulating a kidney to release sodium into the urine hence more water is pulled from blood into the urine and thus frequent urination [81]. Diuretics are commonly used to treat heart failure and other conditions such as liver or kidney disorders that cause fluid retention or edema in the body [82].

Conventional diuretics have been used for the management of the health conditions. Such diuretics are reported to have side effects including, upset of bloodstream salt balance, commonly resulting into low blood level of potassium, sodium, and magnesium and high level of calcium; stomach upset; dizziness on standing; and worsening diabetes and gout conditions [82,83]. Yet, the effect of diuretics on the occurrence of gout may depends on the condition for which the diuretics are given rather than ensuing from the drugs themselves [84]. In addition, renal handling of urate depends on the type of diuretic used, those with uricosuric properties may also help treatment of gout or the weaker may have low risks while the stronger may have higher risks on the occurrence of gout [84].

Conversely, natural diuretics particularly veggies and fruits are high in water and potassium (and some in magnesium and calcium) which help to offset the constriction of blood vessels that makes one feel bloated in case of excess sodium $[85,86]$. Furthermore, natural diuretics have been used 
in treatment of swelling and rheumatism as well as some have properties of reducing uric acid in the body[87].

In this study 40\% (32 species) of MPs were found to be used as diuretic agents and the respondents agreed on the use at ICF of 0.627. From these diuretic plants, 59.4\% (19 species) of them were used both as diuretic agents and for the treatment of joints pains and inflammation. Amongst species the most commonly used diuretic agent was Withania somnifera, followed by Rhamnus Prinoides, Rapanea melanophloeos, Rhamnus staddo, Chenopodium schraderianum, Piper capense, Helinus mystacinus and Acacia nilotica. The observation that some MPs were used as diuretic agents and in treatment of joints' pain and inflammation could be supported by the fact that diuretics have the capacity of removing edema or fluid retained in the body as well as some have uricosuric properties which remove uric acid from the body[87]. Moreover, irrespective of the use of the MPs as diuretic agents, no side effects associated with diuresis were reported in this study as compared to those possessed by the conventional diuretics. This observation could be supported by the fact that most natural diuretics as discussed early are known to contain high amount of water, potassium and sometimes calcium and magnesium which have the capacity of offsetting the effect of excess sodium [85,86]. In addition, mixture of herbal decoction and meat broth or stock, and decoction of MPs were the most commonly used preparations. This could also have significant contribution in prevention of dehydration and other related side effects as both of the preparations have plenty of water and possibly the necessary minerals. The use of these diuretic agents in the current study is supported by the study showing that Withania somnifera in Ayurveda healthcare system of India is known as a prominent herbal Rasayana with diuretic property [36]. So, MPs with diuretic properties that are also used in management of joints' pain and inflammation are potential sources for discovery of diuretic and uricosuric drugs that could be used in management of gout and other related health conditions. In addition, the use of diuretic agents along with plenty of fluid and minerals could be the best approach in management of gout and other related health conditions.

Still, this study recorded some MPs used in management of food digestion, constipation, stomach gas or bloating, the conditions related to digestion system. Digestion system has an important role on the gout health conditions and some of its disorders are the risk factors for the disease [88]. Studies have shown that extensive degradation of a substantial amount of uric acid occurs in human 
with carbon dioxide and ammonia being principal uricolytic products [88]. Intestine, a digestive organ known for its contribution in elimination of one-third of uric acid formed daily in a person [88]. The elimination of uric acid in the gut is through uricolysis supported by intestinal bacteria which degrades uricolysis products particularly carbon dioxide; whereas, the formed products are excreted through feces [88]. It is therefore logical to ascertain that any factor that affect the normal function of digestion system including breakdown and excretion of uric acid it has contribution in the development of gout.

Constipation, a less than three (3) number of bowl movement per week [89] it is a clear indication of lower defecation rate hence the slow excretion rate of uric acid. Constipation is one of the symptoms of gastrointestinal disorders that has various etiologies including mechanical, metabolic, neuropathies and myopathies causes that may affects coordination of bowl motility, mucosal transport or defecation reflexes [89-91]. Some causes of constipation include colonic malignancy or sensorimotor dysfunction, bowl or pelvic cancers, cancer therapy and uremia [91]. In addition to the causes, risks factors such as female sex, older age, sedentary life style, low fiber diet, malnutrition, polypharmacy and low social economic status may result into constipation [89]

Moreover, indigestion, a group of symptoms ranging from pain or discomfort to postprandial fullness, early satiation, burping, abdominal bloating, gurgling sounds, or even nausea and vomiting, is another condition affecting digestive system. Indigestion is known to be caused by intra-abdominal, dietary and lifestyle factors that are categorized into physiological, biological, psychological and environmental mechanisms [92]. Furthermore, indigestion relates to other health conditions that are known to have influence on gout conditions.

Hyperchlorhydria, a high stomach acid, is a common symptom known to be associated with indigestion as well as other health conditions such as gastritis, peptic ulcer disease, renal failure and some cancers $[14,16,17]$. Hyperchlorhydria symptoms include abdominal pain, heartburn, nausea, vomiting of sour liquid, gas and bloating, belching, flatulence, and constipation. Furthermore, some of the health conditions are known as the factors for occurrence of hyperchlorhydria and some are results of the health conditions. Studies have shown that gastrin, a larger precursor for various biologically active peptides, has an important role in meal-stimulated gastric acid secretion, epithelia cell proliferation of gastrointestinal tract and sometime its products can serve as autocrine growth factor for colorectal cancers development [93]. Overexpression of 
gastrin due to gastrin secreting tumor (Zollinger-Ellison syndrome) or the presence of some bacterial infection such as Helicobacter pylori results into hyperchlorhydria and consequently peptic ulcers and thickening of gastro-intestinal mucosa [16,93].

Furthermore, hyperchlorhydria is found to be one of marked conditions in gout patients. The condition has been associated with delayed starch digestion and flatulence, followed by enlargement of the liver, a condition if not relieved is succeed with characteristic arthritic attacks [94]. The liver is found to be the source of glycocin which is suggested to be responsible in production of uric acid through its conjunction with urea in the kidney where excretion of uric acid occurs hence its disorder may result into gout [94]. Still, some other disorders of the liver particularly glycogen storage disease type Ia is also known to results into gout [19]. Defective enzyme involved in the this liver disorder does not only affect the liver it may also cause damage to the kidney an important organ for excretion of uric acid and other wastes [95]. In addition, glycogen storage disease type Ia is also known to be the main cause of gout in premenopausal patients $[19,96]$.

In view of the disorders of digestive system it is clear that the symptoms or health conditions particularly constipation, stomach gas or bloating reported in this study, are the indication of the digestive system disorders of which some are associated or are the risk factors for gout condition. Thus, MPs used in management of the symptoms play an important role in the health of the digestive system and may have potential effects on the digestive disorders underlying causes or its consequences related the gout condition.

In the current study, three (3) species of MPs were used in management of constipation, stomach gas or bloating whereby the respondents agreed on the uses at ICF of 0.667. The most commonly used MP to treats the conditions was Physalis peruviana, followed by Ocimum gratissimum. Furthermore, five (5) species of MPs were used in facilitating food digestion or preventing indigestion at ICF of 0.667; whereas, the most commonly used MP was Acacia nilotica.

The use of these MPs in management of digestive system disorders as well as their potential effects on gout condition in this study is supported by findings of other studies. Physalis peruviana is known to have antioxidant activity and inhibitory effect on xanthine oxidase activities. It is a widely used herb for treating various health conditions including cancer, hepatitis and rheumatism. Furthermore, Ocimum gratissimum is also known for its antioxidant, anti-inflammatory, anti- 
diarrheal activity as well as relaxant effect on gastro intestinal tract [97-99]. Moreover, it is used against gastrointestinal helminths, diarrhea or stomach upset and bacterial infections among other health conditions [97]. In addition, it is used against rheumatism and has hypoglycemia activity that is important in the management of gout as well [97,98]. Still, Acacia nilotica possesses antioxidant, anticancer, anti-diabetic activities and is traditionally used for nutritive purpose, against diarrhea, cancer, induration of liver and spleen and digestive problems [100,101]. Hence, the use of the MPs in management of the digestive system disorders has positive impact to health of the digestive system as well as its conditions associated with gout.

Apart from the flora used in the Maasai TM in management of various ailments including gout symptoms and its associated health conditions as discussed early, the current study recorded some flora used in the Maasai FS. Most flora involved in the Maasai FS were used for food sources, food processing or storage purpose. However, some of them had also medicinal values as detailed in Table 2.

The most commonly used food source plant recorded in this study was Vangueria infausta and the study by Maroyi, support its use as the food source as well as a medicine for treating various health conditions including gastrointestinal disorders, parasitic worms and abdominal pains [102]. Such nutraceutical properties of Vangueria infausta play its role in health of digestive system; consequently, may have potential effect on gout condition. Besides, the most commonly used plants for food processing or storage purpose in this study was Olea europaea subsp. Africana which was used for food preservation, taste and flavor of a liquid food while Lagenaria siceraria was used for storage purpose of the liquid food. Olea europaea subsp. Africana is known for its antihypertensive, hypoglycemic, antioxidant and antibacterial activities [103]. Furthermore, Lagenaria siceraria fruit has been used traditionally as antidiabetic remedy as well as it has a capacity of enhancing stability of stored herbal concoction in its dry fruit [104,105]; though, its effect on food is not well known. Subsequently, such food source plants and those used in food processing and storage purpose in this study may have potential contribution in the management of gout and other health conditions in addition to their reported uses. 


\section{Conclusion}

The current study gathered the knowledge held by MSPs in their indigenous FS and TM, along with assessing the ethnobotanical knowledge available in the public domain particularly on open markets. The study area in Monduli district, Arusha has diverse flora (101 species) used mainly for medicinal purpose, $53.69 \%$ (80 species) in treating or managing various human ailments or health conditions; food processing and storage, 21.48\% (32 species); food sources, 19.46\% (29 species); and other uses, 5.37\% (8 species). This study has shown that the MSPs of the area have rich knowledge on their FS and TM; whereas, the flora is an integral part mainly in the primary healthcare and indigenous food system as well as income generation in the Maasai community. Due to limited access of modern healthcare services, cultural conservatism, and economic insufficiency to meet the prices of available modern healthcare services, flora, mostly MPs are the most reliable source of healthcare services which more often is provided at household level in the community.

MPs of the area were used to treat more than 38 ailments, and some induce diuresis, diarrhea, and vomiting as the approaches involved in the treatments. Some MPs were used to manage health conditions associated with gout, which included: joints pain and inflammation, pressure, diabetes, 'OSUPETAI', digestive system disorders, and diuresis. In addition, some were used in the indigenous FS with their medicinal values against the ailments including health conditions associated with gout.

Most $(88.79 \%)$ of the flora are found in the wild habitat where anthropogenic activities are evolving and thus are exposed to demolition. Consequently, this calls for establishment of sustainable integrated natural resources management system on the area as soon as possible. Indigenous stewardship of the natural resources, including flora used in the indigenous FS and TM needs documentation and improvement by government and non-government environmental restoration programs to preserve the flora of the area. Additional plant use categories including, firewood, construction, bee forage, ornamental, fodder, shade, etc. requires documentation so as to augment the preservation of the vital natural resources.

This study recommends an in-depth laboratory investigation of the frequently cited MPs with high FL, RFCs used in management of the ailments including joints pain and inflammation, diuresis, and digestive system disorders. This would have potential contribution to the current global drug 
discoveries for the management of gout condition and other reported health conditions. Also, further study of the Maasai food system is required to ascertain its influence on gout and other reported health conditions.

\begin{abstract}
Abbreviations
FL: Fidelity level; FS: Food system; ICF: Informant consensus factor; MP/MPs: Medicinal plant(s); MSP/MSPs: Maasai practitioner(s); RFC: Relative frequency of citation; RFCs: Specific relative frequency of citation; TM/TMs: Traditional medicine(s); UV: Use value
\end{abstract}

\title{
Acknowledgements
}

We extend our deepest gratitude to the community of Monduli district, Arusha particularly the one living in Engalaoni, Imbibia, Lossimingori, Lemiyoni, Makuyuni juu, Mlimani and Zaburi villages, as well as MSPs who participated consciously in the present study. The local authorities are exceedingly cherished for the extrovert support given to us during the fieldwork in the study area. We thankfully concede the staff of the National Herbarium (TPRI) for assisting us in herbarium work. Special gratefulness goes to Gabriel S Laizer (Field botanist) and his team members, Dr. Neduvoto Piniel Mollel (Head of Division, National Herbarium, TPRI), John Elia Ntandu (TPRI researcher), and Diana Mbaruku (TPRI herbarium data base Logger) for their unreserved assistance during the identification and validation of the specimens. Also, special thanks go to Tanzania Forest Service (TFS) of Monduli District, Arusha for their great support and permission to include some of the areas under their Authority in this Study.

\section{Funding}

The Tanzania Ministry of Education Science and Technology (MoEST) has covered cost of the current study.

\section{Availability of data and materials}

Data generated or analyzed during this study are included in this article 


\section{Authors' contribution}

RPC developed the study design and protocols, collected the data, carried out the statistical analysis, and prepared the draft manuscript. MNC and JR were involved in the design and protocol development, provided consistent comments during the analysis and write-up of the manuscript, and rigorously reviewed it. All authors have read, approved and agreed on the submission of the final manuscript.

\section{Authors' information}

Richard Paul Clement - M.Sc. (Marine Sciences); Assistant Lecturer in Chemistry Department at Mkwawa University College of Education, a Constituent College of the University of Dar es Salaam, Tanzania and a PhD candidate in the School of Life Science specialized on Health and Biomedical Sciences at The Nelson Mandela African Institution of Science and Technology, and currently working on the validation of anti-hyperuricemia traditional MPs of Tanzania.

Musa N Chacha - MPhil \& PhD in Natural Products Chemistry; Senior Lecturer at The Nelson Mandela African Institution of Science and Technology, Arusha, Tanzania and working on development of antimicrobial, anticancer and insecticidal agents from medicinal plants, marine invertebrates and microorganisms.

Jofrey Raymond - PhD in Life Science (Food and Nutritional Sciences); Lecturer at The Nelson Mandela African Institution of Science and Technology, Arusha, Tanzania and working on Food systems for nutrition, Nutrition-sensitive agriculture, Microbiome-nutrition, Personalized nutrition, Nutritious product formulation and development, Formulation methods for product stability, Novel technologies in food and nutrition, Linear and goal programming in nutrition, Food economics, Business models in food and nutrition.

\section{Ethical approval and consent to participate}

This study was conducted following a thoroughly review of the study protocols by scholars in the ethnobotanical field of the study from different research works. Moreover, official permission support letter was provided by Nelson Mandela African Institution of Science and Technology (NM-AIST) administration. The study participants were informed about the benefits of taking part 
in the present study. To get their consent, a briefly discussion was made with the MSPs and the aim of the study was explained so that they would be clear about the purpose of documenting the flora and their knowledge on the same for academic use with no commercialization being involved. It was also made clear that the usual benefits they get by accessing and using resources will not be affected by giving full information about the flora to the investigator. Verbal consent was obtained from the study participants before beginning the study. Costs of travel and time spent were compensated with modest payments.

\section{Consent for publication}

Not applicable

\section{Competing interests}

The authors declare that they have no competing interests.

\section{Authors details}

${ }^{1}$ School of Life Sciences and Bio-engineering, The Nelson Mandela African Institution of Science and Technology, P. O. Box 447, Arusha, Tanzania.

${ }^{2}$ Mkwawa University College of Education, a Constituent College of the University of Dar es Salaam, P. O. Box 2513, Iringa, Tanzania.

\section{References}

1. Amjad MS, Zahoor U, Bussmann RW, Altaf M. Ethnobotanical survey of the medicinal flora of Harighal , Azad Jammu \& Kashmir, Pakistan. J Ethnobiol Ethnomed. 2020;16(65):1-28.

2. Kuhnlein H V. Food system sustainability for health and well-being of Indigenous Peoples. Public Health Nutr. 2014;18(13):2415-24.

3. Kimondo JW. An Evaluation of Antioxidant and Anti-inflammatory Effects of Natural Foods and Medicinal Plants of the Ilkisonko Maasai Community, Kenya. University of Nairobi; 2020.

4. Kaj Århem. Maasai Food Symbolism. Antropos. 1989;84(1):1-23.

5. Oiye S, Oniang'o R, Simel JO, Johns T. The Maasai food system and food and nutrition security. In: Indigenous Peoples' food systems. McGill University Library; 2006. p. 231- 
49.

6. Makule E. Ethnopharmacological survey and phytochemical investigation of Maasai traditional medicinal plants from north-eastern Tanzania Dissertation. University of Regensburg; 2015.

7. Amri E, Kisangau DP. Ethnomedicinal study of plants used in villages around Kimboza forest reserve in Morogoro, Tanzania. J Ethnobiol Ethnomed [Internet]. 2012;8(1):1-9. Available from: http://www.ethnobiomed.com/content/8/1/1

8. Ngowi NJ. Ethnobotanical Study of Medicinal Plants in Kondoa Eroded Area of Central Tanzania. Int J Sci Basic Appl Res [Internet]. 2015;21(1):223-33. Available from: http://gssrr.org/index.php?journal=JournalOfBasicAndApplied

9. URT (United Republic of Tanzania). Fifth National Report on the Implementation of the Convention on Biological Diversity. Division of Environment, Vice President's Office. Dar es Salaam; 2014.

10. Pereus D, Otieno JN, Ghorbani A, Kocyan A, Hilonga S, de Boer HJ. Diversity of Hypoxis species used in ethnomedicine in Tanzania. South African $J$ Bot [Internet]. 2019;122(March):336-41. Available from: https://doi.org/10.1016/j.sajb.2018.03.004

11. Moshi MJ, Otieno DF, Weisheit A. Ethnomedicine of the Kagera Region, north western Tanzania. Part 3: Plants used in traditional medicine in Kikuku village, Muleba District. J Ethnobiol Ethnomed. 2012;8:1-5.

12. Nahashon M. Conservation of Wild-harvested Medicinal Plant Species in Tanzania. Examensarbete i Hållbar Utveckl [Internet]. 2013;50. Available from: http://www.divaportal.org/smash/get/diva2:615493/FULLTEXT01.pdf

13. Christensen DL, Boit MK, Mwaniki DL, Kilonzo B, Tetens I, Kiplamai FK. Cardiorespiratory Fitness and Physical Activity in Luo , Kamba , and Maasai of Rural Kenya. Am J ofHuman Biol. 2012;1-7.

14. Cheney WF. Hyperchlorhydria. Cal State J Med. 1911;9(2):48-51.

15. Liu X, Chen R, Shang Y, Jiao B, Huang C. Lithospermic acid as a novel xanthine oxidase inhibitor has anti-inflammatory and hypouricemic effects in rats. Chem Biol Interact. 2008;176(2-3):137-42.

16. Alter DN. Clinical chemistry of the gastrointestinal disorders. In: Contemporary Practice in Clinical Chemistry [Internet]. Elsevier Inc.; 2020. p. 561-72. Available from: http://dx.doi.org/10.1016/B978-0-12-815499-1.00032-6

17. Friesen SR, Tomita T. Pseudo-Zollinger-Ellison Syndrome: Hypergastrinemia, Hyperchlorhydria without Tumor pseudo-Zollinger-Ellison. Ann Surg. 1981;194(4):48191.

18. Vizcaíno Luna Y, Bermúdez Marrero WM, Bermúdez Marrero WA, Egües Mesa JL, Cárdenas Domínguez T, Prendes García E. Gout Arthritis. Ten years of follow up. Rev Cuba Reumatol. 2019;21(3):1-14. 
19. Zhang B, Zeng X. Tophaceous gout in a female premenopausal patient with an unexpected diagnosis of glycogen storage disease type Ia: a case report and literature review. Clin Rheumatol [Internet]. 2016; Available from: http://dx.doi.org/10.1007/s10067-016-3290-1

20. Pergola T. "Changes in Using and Conserving Medicinal Plants in Maasai Villages in Monduli District, Tanzania ." Arusha; 2001.

21. Kaswamila A. Human-wildlife conflicts in monduli District, Tanzania. Int J Biodivers Sci Manag. 2009;5(4):199-207.

22. URT (United Republic of Tanzania). 2012 Population and Housing Census. National Bureau of Statistics (NBS) and Office of Chief Government Statistician (OCGS). Dar es Salaam and Zanzibar; 2014.

23. FTEA [Flora of Tropical East Africa] 1952-2012. Flora of Tropical East Africa. In: Royal Botanic Garden, Kew. 2012.

24. Issa TO, Mohamed YS, Yagi S, Ahmed RH, Najeeb TM, Makhawi AM, et al. Ethnobotanical investigation on medicinal plants in Algoz area (South Kordofan), Sudan. J Ethnobiol Ethnomed. 2018;14(1):1-22.

25. Amjad MS, Qaeem M, Ahmad I, Khan SU, Chaudhari SK, Malik NZ, et al. Descriptive study of plant resources in the context of the ethnomedicinal relevance of indigenous flora: A case study from Toli Peer National Park , Azad Jammu and Kashmir ,. PLoS One. 2017;131.

26. Jin B, Liu Y, Xie J, Luo B, Long C. Ethnobotanical survey of plant species for herbal tea in a Yao autonomous county (Jianghua, China): Results of a 2-year study of traditional medicinal markets on the Dragon Boat Festival. J Ethnobiol Ethnomed. 2018;14(1).

27. Tuasha N, Petros B, Asfaw Z. Medicinal plants used by traditional healers to treat malignancies and other human ailments in Dalle District, Sidama Zone, Ethiopia. J Ethnobiol Ethnomed. 2018;14(1):1-21.

28. Kiringe JW. A Survey of Traditional Health Remedies Used by the Maasai of Southern Kaijiado District , Kenya. Ethnobot Res Appl. 2006;4:61-73.

29. Bruderer S, Bodmer M, Jick SS, Meier CR. Use of Diuretics and Risk of Incident Gout. Arthritis Rheumatol. 2014;66(1):185-96.

30. So AK, Martinon F. Inflammation in gout: Mechanisms and therapeutic targets. Nat Rev Rheumatol [Internet]. 2017;13(11):639-47. Available from: http://dx.doi.org/10.1038/nrrheum.2017.155

31. Kamau LN. Study of Extent of Use, Efficacy and Acute Toxic Effects of Selected Antidiabetic Plants in Nyeri and Narok Counties, Kenya. University of Nairobi; 2018.

32. Innocent E, Augustino S, Kisinza W. Plants Used to Control Mosquitoes and Treat Mosquito Related Diseases in Maasai-land of Longido District, Tanzania. European J Med Plants. 2016;12(2):1-12.

33. Kamau LN, Mbaabu PM, Mbaria JM, Gathumbi PK, Kiama SG. Ethnobotanical survey and 
threats to medicinal plants traditionally used for the management of human diseases in Nyeri County, Kenya. Tang [Humanitas Med. 2016;6(3):1-15.

34. Seifu T, Asres K, Gebre-Mariam T. Ethnobotanical and ethnopharmaceutical studies on medicinal plants of Chifra District, Afar Region, North Eastern Ethiopia. Ethiop Pharm J. 2006;24(1).

35. Gupta G, Rana A. Withania somnifera (Ashwagandha): A Review. Pharmacogn Rev. 2007;1(1):129-36.

36. Dar NJ, Hamid A, Ahmad M. Pharmacologic overview of Withania somnifera, the Indian Ginseng. Cell Mol Life Sci. 2015;72(23):4445-60.

37. Gallego MG, Gordon MH, Segovia F, Almajano Pablos MP. Gelatine-based antioxidant packaging containing Caesalpinia decapetala and tara as a coating for ground beef patties. Antioxidants. 2016;5(2).

38. Pawar CR, Surana SJ. Antioxidant properties of the methanol extract of the wood and pericarp of Caesalpinia decapetala. J Young Pharm [Internet]. 2010;2(1):45-9. Available from: http://dx.doi.org/10.4103/0975-1483.62212

39. Bhadoriya U, Sharma P, Solanki SS. In Vitro Free Radical Scavenging Activity of Gallic Acid Isolated From Caesalpinia Decapetala Wood. Asian Pacific J Trop Dis [Internet]. 2012;2(SUPPL2):S833-6. Available from: http://dx.doi.org/10.1016/S2222$1808(12) 60274-6$

40. Chen GL, Mutie FM, Xu YB, Saleri FD, Hu GW, Guo MQ. Antioxidant, anti-inflammatory activities and polyphenol profile of rhamnus prinoides. Pharmaceuticals. 2020;13(4):1-12.

41. Madivoli ES, Maina EG, Kairigo PK, Murigi MK, Ogilo JK, Nyangau JO, et al. In vitro antioxidant and antimicrobial activity of Prunus africana (Hook. f.) Kalkman (bark extracts) and Harrisonia abyssinica Oliv. extracts (bark extracts): A comparative study. J Med Plants Econ Dev. 2018;2(1):1-9.

42. Das DK, Engelman RM, Clement R, Otani H, Prasad MR, Rao PS. Role of xanthine oxidase inhibitor as free radical scavenger: A novel mechanism of action of allopurinol and oxypurinol in myocardial salvage. Biochem Biophys Res Commun. 1987;148(1):314-9.

43. Tung Y-T, Chang S-T. Inhibition of Xanthine Oxidase by Acacia confusa Extracts and Their Phytochemicals. J Agric Food Chem. 2010;781-6.

44. Ismael TK. Antimicrobial activity of Loranthus europaeus L . and Lawsonia inermis L . extracts against clinical Methicillin-resistant Staphylococcus aureus isolated from boil infections. Tikrit J Pure Sci. 2018;23(6):24-30.

45. Kirkcaldy RD, Harvey A, Papp JR, Rio C del, Soge OO, Holmes KK, et al. Antimicrobial Susceptibility Surveillance - The Gonococcal Isolate Surveillance Project, 27 Sites , United States , 2014. 2016. (Surveillance Summaries; vol. 65).

46. Reekie J, Donovan B, Guy R, Hocking JS, Kaldor JM, Mak D, et al. Risk of Ectopic Pregnancy and Tubal Infertility Following Gonorrhea and Chlamydia Infections. Clin Infect Dis. 2019;69(9):1621-3. 
47. Brunham RC, Rey-ladino J. Immunology of Chlamydia Infection: Implications for a Chlamydia Trachomatis Vaccine. Nat Rev| Immunol. 2005;5:149-61.

48. Alary M, Laga M, Vuylsteke B, Nzila N, Piot P. Signs and symptoms of prevalent and incident cases of gonorrhea and genital chlamydial infection among female prostitutes in Kinshasa, Zaire. Clin Infect Dis. 1996;22(3):477-84.

49. Trayes KP, Studdiford JS, Pickle S, Tully AS. Edema: Diagnosis and Management. Am Fam Physician. 2013;88(2):102-10.

50. Nicolaides AN. From Symptoms To Leg Edema: Efficacy Of Daflon $500 \mathrm{mg}$. Angiology. 2003;54(1):33-44.

51. Ramelet AA. Daflon $500 \mathrm{mg}$ : Symptoms and edema - Clinical update. Angiology. 2005;56(SUPPL. 1):25-32.

52. Borenstein DG, Calin A. Fast Facts : Low Back Pain [Internet]. 2nd edn. Oxford: Health Press Limited; 2012. 1-143 p. Available from: www.fastfacts.com

53. Shiri R, Solovieva S, Husgafvel-pursiainen K, Telama R, Yang X, Viikari J, et al. The role of obesity and physical activity in non-specific and radiating low back pain_ The Young Finns study. Semin Arthritis Rheum [Internet]. 2013;42(6):640-50. Available from: http://dx.doi.org/10.1016/j.semarthrit.2012.09.002

54. Basson R. Testosterone therapy for reduced libido in women. Ther Adv Endocrinol Metab. 2010;1(4):155-64.

55. Corona G, Rastrelli G, Ricca V, Jannini EA. Risk Factors Associated with Primary and Secondary Reduced Libido in Male Patients with Sexual Dysfunction. J Sex Med. 2013;1074-89.

56. Cumming GP, Currie HD, Moncur R, Lee AJ. Web-based survey on the effect of menopause on women' $\mathrm{s}$ libido in a computer-literate population. Menopause Int. 2009; 15(1):8-12.

57. Dissanayake D, Wijesinghe P, Ratnasooriya W, Wimalasena S. Effects of zinc supplementation on sexual behavior of male rats. J Hum Reprod Sc. 2009;2(2):57-61.

58. Malavige LS, Jayaratne SD, Kathriarachchi ST, Sivayogan S, Fernando DJ, Levy JC. Erectile Dysfunction Among Men with Diabetes is Strongly Associated with Premature Ejaculation and Reduced Libido. J Sex Med. 2008;5:2125-34.

59. Saguil A. Evaluation of the patient with muscle weakness. Am Fam Physician. 2005;71(7):1327-36.

60. Noakes TD. Fatigue is a brain-derived emotion that regulates the exercise behavior to ensure the protection of whole body homeostasis. Front Physiol. 2012;3(82):1-13.

61. Torres-harding S, Jason LA. 1 What Is Fatigue ? History and Epidemiology. 1994;

62. Timmermans EJ, Schaap LA, Herbolsheimer F, Dennison EM, Maggi S, Pedersen NL, et al. The Influence of Weather Conditions on Joint Pain in Older People with Osteoarthritis : Results from the European Project on OSteoArthritis. J Rheumatol. 2015;42(10):1-8. 
63. Lee M, Ohde S, Urayama KY, Takahashi O, Fukui T. Weather and Health Symptoms. Int J Environ Res Public Heal. 2018;15(1670):1-15.

64. Bakar MA, Mckimm J, Haque SZ, Haque M. Chronic tonsillitis and biofilms : a brief overview of treatment modalities. J Inflamm Res. 2018;329-37.

65. Jensen A, Bank S, Hansen TM, Kristensen LH, Prag J. Fusobacterium necrophorum tonsillitis: An important cause of tonsillitis in adolescents and young adults. Clin Microbiol Infect [Internet]. 2014; Available from: http://dx.doi.org/10.1016/j.cmi.2014.09.020

66. Loganathan A, Arumainathan UD, Raman R. Comparative study of bacteriology in recurrent tonsillitis among children and adults. Singapore Med J. 2006;47(4):271-5.

67. Ghali MJA, Mukhaimer MN, Yousef MKA, Naser SSA. Expert System for Problems of Teeth and Gums. Int J Eng Inf Syst. 2017;1(4):198-206.

68. Johnstone L, Spence D, Koziol-mcclain J. Oral Hygiene Care in the Pediatric Intensive Care Unit : Practice Recommendations. Pediatr Nurs. 2010;36(2):85-96.

69. Marmura MJ. Triggers, Protectors, and Predictors in Episodic Migraine [Internet]. Department of Neurology Faculty Papers. 2018. (170; vol. Paper 170). Available from: https://jdc.jefferson.edu/neurologyfp/170

70. Grosberg BM, Solomon S, Lipton RB. Nummular Headache. Curr Pain Headache Rep. 2007;11:310-312.

71. Mattsson P. Headache caused by drinking cold water is common and related to active migraine. Cephalalgia. 2001;21:230-5.

72. Daveson AJ, Jones DM, Gaze S, Mcsorley H, Clouston A, Cooke S, et al. Effect of Hookworm Infection on Wheat Challenge in Celiac Disease - A Randomised DoubleBlinded Placebo Controlled Trial. PLoS One. 2011;6(3):1-9.

73. Stoltzfus RJ, Dreyfuss ML, Chwaya HM. Hookworm Control as a Strategy to Prevent Iron Deficiency. Nutr Rev. 1997;55(6):223-32.

74. Hyun HJ, Kim EM, Park SY, Jung JO, Chai JY, Hong ST. A case of severe anemia by Necator americanus infection in Korea. J Korean Med Sci. 2010;25(12):1802-4.

75. Loukas A, Hotez PJ, Diemert D, Yazdanbakhsh M, McCarthy JS, Correa-Oliveira R, et al. Hookworm infection. N Engl J Med. 2004;351(8):799-807.

76. Taylor MJ, Hoerauf A, Bockarie M. Lymphatic filariasis and onchocerciasis. Lancet. 2010;376(9747):1175-85.

77. Sultana F, Juliana FM, Islam MJ, Asaduzzaman M. Impact of Lymphatic Filariasis ( LF ) on Hemoglobin Content and Anemia : A Cross-Sectional Based Study. J Heal Med Nurs. 2017;44:30-2.

78. Amenya HZ, Gathumbi PK, Mbaria JM, Thaiyah AG, Thoithi GN. Sub-acute toxicity of the chloroformic extract of Rapanea melanophloeos (L.) Mez in rats. J Ethnopharmacol [Internet]. 2014;154(3):593-9. Available from: http://dx.doi.org/10.1016/j.jep.2014.04.001 
79. Mehrbod P, Abdalla MA, Fotouhi F, Heidarzadeh M, Aro AO, Eloff JN, et al. Immunomodulatory properties of quercetin-3-O- $\alpha$-L-rhamnopyranoside from Rapanea melanophloeos against influenza a virus. BMC Complement Altern Med. 2018;18(1):1-10.

80. Ndontsa BL, Dongmo FLM, Tala MF, Wabo HK, Zeng GZ, Tan NH, et al. A new cytotoxic alkenylresorcinol from embelia schimperi. Rec Nat Prod. 2014;8(1):37-40.

81. Zafar O. Diuretic Activities of Aqueous Methanolic Extracts of Watermelon and Bottle Gourd Seeds In Albino Rats. The Islamia University of Bahawalpur; 2015.

82. Oh SW, Han SY. Loop Diuretics in Clinical Practice. Electrolyte Blood Press. 2015;13:1721.

83. Better O s., Busch A, Dorup J, Endou H, Greger R, Guder WG, et al. Diuretics: Handbook of Experimental Pharmacology Volume 117. Greger RF, Knauf H, Mutschler E, editors. Hong Kong: Springer-Verlag Berlin Heidelberg; 1995. 1-517 p.

84. Pascual E, Perdiguero M. Gout, diuretics and the kidney. Ann Rheum Dis. 2006;65:981-3.

85. Shi Y, An S, Wan Y, Liu Q. The intake of potassium-rich food by the potassium-requiring heart disease patients and potential mechanism. Eur J Prev Cardiol. 2019;26(7):NP1-2.

86. Hedaoo SA, Bodhankar MM. Advantages of Natural Diuretics Over Synthetic. World J Pharm Pharm Sci. 2019;8(3):310-27.

87. Sharma N, Singh NR, Varsakiya J. Management of Vatarkta (Gout) in Ayurveda : Review. World J Pharm Res. 2019;8(6):1319-29.

88. Sorensen B. Role of the Intestinal Tract in the Elimination of Uric Acid. Arthritis Rheum. $1965 ; 8(5)$.

89. Bahna H, Alame AM. Evaluation of Constipation. Clin Colon Rectal Surg 2012. 2012;25:511.

90. Portenoy RK. Constipation in the Cancer Patient: Causes and Management. Med Clin North Am [Internet]. 1987;71(2):303-11. Available from: http://dx.doi.org/10.1016/S00257125(16)30872-0

91. Dinning PG, Smith TK, Scott SM. Pathophysiology of colonic causes of chronic constipation. Neurogastroenterol Motil. 2009;21(2):20-30.

92. Derakhshan AR, Yousefi M, Dehghan S, Zargaran A, Khodadoost M. Digestion process and causes of indigestion based on Avicenna's view and modern medicine. Tradit Med Res. 2019;(March).

93. Shulkes A, Baldwin GS. Gastrin [Internet]. Second Edi. Handbook of Biologically Active Peptides. Elsevier Inc.; 2013. 1219-1226 p. Available from: http://dx.doi.org/10.1016/B978-0-12-385095-9.00165-2

94. Stockton CG. Gastro-intestinal and Hepatic Relations of Gout [Internet]. 1897 p. 222-3. Available from: http://jama.jamanetwork.com/

95. Reitsma-Bierens WCC. Renal complications in glycogen storage disease type I. Eur J 
Pediatr. 1993;152(1):60-2.

96. Sever S, Weinstein DA, Wolfsdorf JI, Gedik R, Schaefer EJ. Glycogen storage disease type Ia : Linkage of glucose, glycogen, lactic acid, triglyceride, and uric acid metabolism. J Clin Lipidol. 2012;6:596-600.

97. Akinmoladun AC, Ibukun E, Obuotor EM, Farombi O. Phytochemical constituent and antioxidant activity of extract from the leaves of Ocimum gratissimum. Sci Res Essays. 2007;2(5):163-6.

98. Aguiyi JC, Obi CI, Gang SS, Igweh AC. Hypoglycaemic activity of Ocimum gratissimum in rats. Fitoterapia. 2000;71(4):444-6.

99. Prabhu KS, Lobo R, Shirwaikar AA, Shirwaikar A. Ocimum gratissimum: A Review of its Chemical, Pharmacological and Ethnomedicinal Properties. Open Complement Med J. 2009; 1(1):1-15.

100. Ali A, Akhtar N, Khan BA, Khan MS, Rasul A. Acacia nilotica : A plant of multipurpose medicinal uses. J Med Plants Res. 2012;6(9).

101. Charles NN, Bonareri NL. An inventory of some medicinal plants used by abagusii traditional healers of South West Kenya. J Med Plant Stud [Internet]. 2020;8(3):127-35. Available from: www.plantsjournal.com

102. Maroyi A. Nutraceutical and ethnopharmacological properties of vangueria infausta subsp. infausta. Molecules. 2018;23(5).

103. Msomi NZ, Simelane MBC. Olea europaea subsp. africana (Oleaceae). Act Ingredients from Aromat Med Plants. 2017;

104. Oseni LA, Iddrisu A-M. An evaluation of relative stabilities of selected local herbal concoctions stored in Calabash fruit pods and clay pot containers. J Chem Pharm Res. 2012;4(1):409-15.

105. Juee LYM, Naqishbandi AM. Calabash (Lagenaria siceraria) potency to ameliorate hyperglycemia and oxidative stress in diabetes. $\mathrm{J}$ Funct Foods [Internet]. 2020;66(January):103821. Available from: https://doi.org/10.1016/j.jff.2020.103821 